\title{
PROCESSAMENTO E AVALIAÇÃO DA QUALIDADE DO NÉCTAR E NÉCTAR LIGHT DE DOIS CULTIVARES DE PÊSSEGO ADAPTADOS AO CLIMA SUBTROPICAL
}

\section{RENATA BASSO BEISMAN}

Engenheira Agrônoma

Orientador: Prof. Dr. JOÃO NUNES NOGUEIRA

Dissertação apresentada à Escola Superior de Agricultura "Luiz de Queiroz", Universidade de São Paulo, para obtenção do título de Mestre em Ciências, Área de Concentração: Ciência e Tecnologia de Alimentos.

P I R A C I C A B A

Estado de São Paulo - Brasil

Julho 2000 
Dados internacionais de Catalogação na Publicação (CIP) DIVISÃO DE BIBLIOTECA E DOCUMENTAÇĀO - Campus "Luiz de Queiroz"/USP

Beisman, Renata Basso

Processamento e avaliação da qualidade do néctar e néctar light de dois cultivares de pêssego adaptados ao clima subtropical / Renata Basso Beisman. - - Piracicaba, 2000

107 p. : il.

Dissertação (mestrado) - Escola Superior de Agricultura Luiz de Queiroz, 2000. Bibliografia.

1. Controle de qualidade 2. Matéria prima 3. Néctar 4. Pêssego 5. Processamento 6. Regiäo subtropical 7. Tecnologia de alimento 8. Tratamento quimico 9. Tratamento térmico 1. Titulo

CDD 664.80425 
Ao amigo, que com suas palavras me ensinou a absoluta

razão da vida.

Ơ̂̉eço 
Aos meus pais e irmão pelo constante incentivo e ajuda.

$\mathrm{E}$ ao meu marido pela compreensão, atenção e amor em todos os momentos desse processo.

Agradeço 


\section{AGRADECIMENTOS}

- Ao Prof. Dr. João Nunes Nogueira, pela orientação, ajuda e profissionalismo durante todo o trabalho realizado.

- As laboratoristas Ivani Marchetto Moreno, Roberta Teresa Rizzo Benato e Juliana Antunes Galvão, pela ajuda e companheirismo.

- As bibliotecárias Beatriz Helena Giongo, pelas correções nas referências bibliográficas e a Midiam Gustinelli, pela ajuda e consultas bibliográficas.

- À equipe de análise sensorial, pela inestimável colaboração.

- À CNPq pelo auxílio financeiro concedido.

- Ao proprietário Murayama e sua esposa, pelo fornecimento da matériaprima deste trabalho.

-À Ajinomoto Interamericana Ind. e Com. Ltda, pelo fornecimento do aspartame utilizado neste trabalho.

- À Sunset Importação e Exportação Ltda, pelo fornecimento do sorbitol pó utilizado neste trabalho.

- Por todas as pessoas que tornaram possível esse trabalho. 


\section{SUMÁRIO}

Página

LISTA DE FIGURAS .................................................................. i

LISTA DE TABELAS ................................................................ vi

RESUMO ........................................................................... ix

SUMMARY ........................................................................

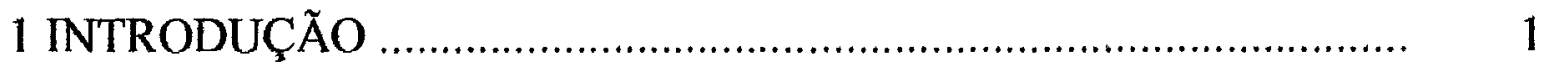

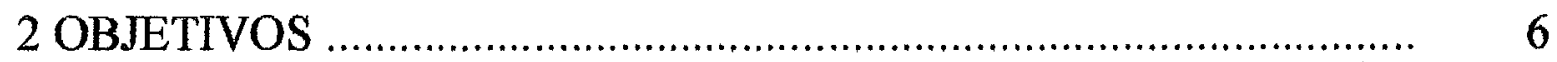

3 REVISÃO DE LITERATURA ............................................ 7

3.1 Considerações gerais ............................................................... 7

3.2 Cultivares de pêssego .............................................................. 11

3.3 Fatores que afetam a qualidade do pêssego ................................. 13

3.3.1 Ácido ascórbico ................................................................. 13

3.3.2 Cor e sabor ..................................................................... 17

3.3.3 Corrosão da lata .................................................................. 20

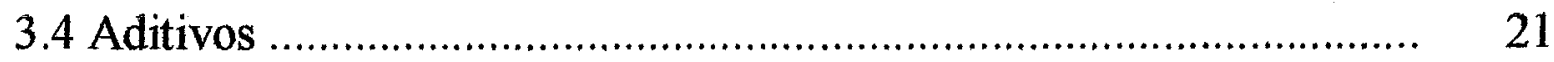

3.4.1 Ácido ascórbico ..................................................................... 23

3.4.2 Ácido cítrico ..................................................................... 24

3.4.3 Sorbato de potássio ........................................................... 24

3.5 Produtos dietéticos ................................................................ 25

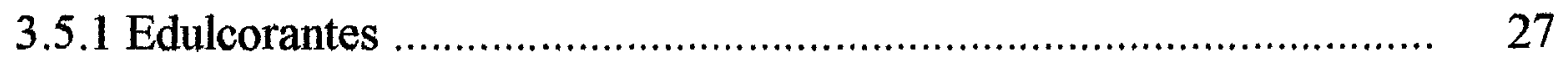

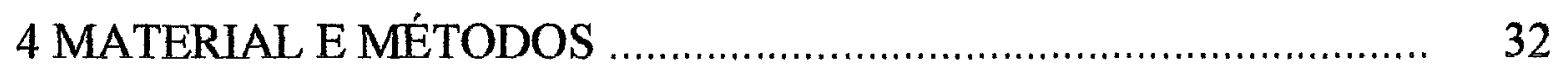

4.1 Matéria-prima .................................................................... 32

4.2 Caracterização da matéria-prima ................................................ 32

4.2.1 Análise física .................................................................. 32

4.2.2 Análise química ................................................................ 33 
4.3 Processamento dos pêssegos ............................................................ 34

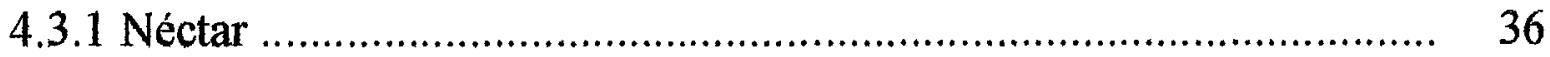

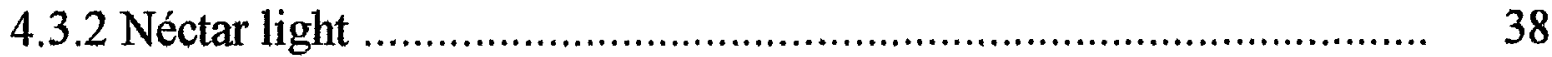

4.3.3 Acondicionamento .................................................................. 41

4.3.4 Recravação .............................................................................. 41

4.3.5 Resfriamento ........................................................................ 41

4.3.6 Armazenamento ………….................................................... 41

4.4 Avaliação do produto processado .................................................. $\quad 42$

4.4.1 Análise química .......................................................................... 42

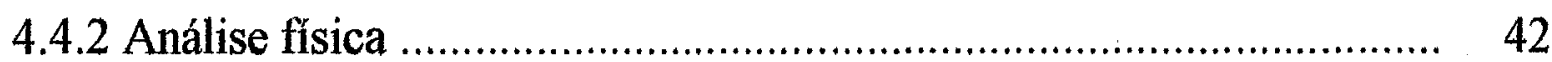

4.4.3 Análise sensorial ................................................................... 43

4.4.4 Análise estatística .................................................................... 45

5 RESULTADOS E DISCUSSÃO ..................................................... 47

5.1 Caracterização da matéria-prima …………………............................ 47

5.1.1 Análise física .......................................................................... 47

5.1.2 Análise química ......................................................................... 49

5.2 Caracterização do néctar ................................................................ 51

5.2.1 Análise física ....................................................................... 51

5.2.2 Análise química ....................................................................... 54

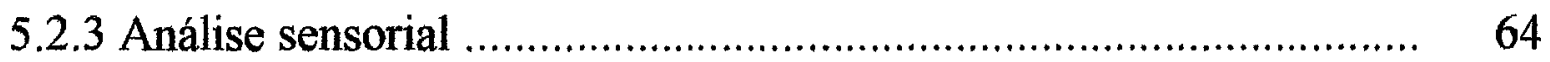

5.3 Caracterização do néctar light .......................................................... 68

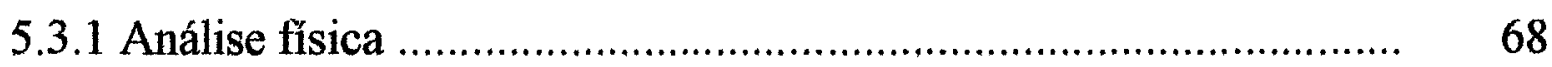

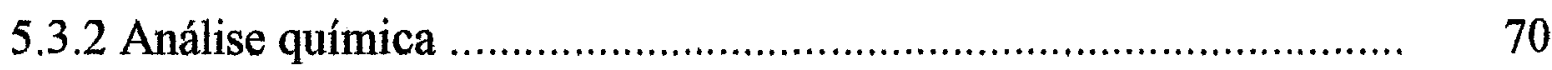

5.3.3 Análise sensorial ...................................................................... 79

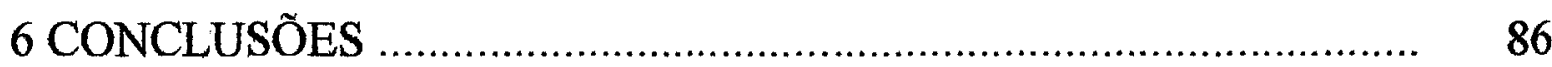

REFERÊNCIAS BIBLIOGRÁFICAS ……………………................. 88 


\section{LISTA DE FIGURAS}

Página

1 Fluxograma do processamento utilizado para a produção do néctar de pêssego

2 Esquema dos tratamentos aplicados ao purê de pêssego para obtenção de néctar

3 Esquema dos tratamentos aplicados ao purê de pêssego para obtenção de néctar light

4 Modelo de ficha utilizado na avaliação sensorial das amostras do néctar quanto à consistência

5 Modelo de ficha utilizado na avaliação sensorial das amostras do néctar quanto ao sabor

6 Modelo de ficha utilizado na avaliação sensorial das amostras de néctar quanto à cor

7 Variação do teor de ácido ascórbico dos néctares da Aurora-1, em função do tempo de armazenamento

8 Variação do teor de ácido ascórbico dos néctares da Dourado-2, em função do tempo de armazenamento

9 Variação do teor de ácido ascórbico dos néctares, em função do tempo de armazenamento

10 Variação da acidez total titulável em néctares da Aurora-1, em função do tempo de armazenamento

11 Variação da acidez total titulável em néctares da Dourado-2, em função do tempo de armazenamento

12 Variação da acidez total titulável em néctares, em função do tempo de armazenamento 
13 Variação do pH dos néctares, em função do tempo de armazenamento

14 Variação do teor de sólidos solúveis totais

dos néctares, em função do tempo de armazenamento .

15 Valores médios das notas obtidas na avaliação sensorial, quanto à cor dos néctares

16 Valores médios das notas obtidas na avaliação sensorial, quanto à consistência dos néctares

17 Valores médios das notas obtidas na avaliação sensorial, quanto ao sabor dos néctares

18 Valores médios das notas obtidas na avaliação sensorial, quanto aos atributos de qualidade dos néctares 68

19 Variação do teor de ácido ascórbico dos néctares light da Aurora-1, em função do tempo de armazenamento 72

20 Variação do teor de ácido ascórbico dos néctares light da Dourado-2, em função do tempo de armazenamento 73

21 Variação do teor de ácido ascórbico dos néctares light, em função do tempo de armazenamento

22 Variação da acidez total titulável dos néctares light da Aurora-1, em função do tempo de armazenamento 76

23 Variação da acidez total titulável dos néctares light da Dourado-2, em função do tempo de armazenamento 
24 Variação da acidez total titulável dos néctares

light, em função do tempo de armazenamento

25 Variação do $\mathrm{pH}$ dos néctares light, em função

do tempo de armazenamento

26 Variação do teor de sólidos solúveis totais

dos néctares light, em função do tempo de

armazenamento

27 Valores médios das notas obtidas na

avaliação sensorial, quanto à cor dos néctares light

28 Valores médios das notas obtidas na

avaliação sensorial, quanto à consistência

dos néctares light

29 Valores médios das notas obtidas na avaliação

sensorial, quanto ao sabor dos néctares light

30 Valores médios das notas obtidas na avaliação

sensorial, quanto aos atributos de qualidade

dos néctares light 


\section{LISTA DE TABELAS}

Página

1 Características físicas dos cultivares de pêssego in natura (matéria-prima)

2 Características químicas dos cultivares de pêssego in natura (matéria-prima)

3 Valores médios do vácuo (pol.Hg) das latas dos néctares, em função do tempo de armazenamento

4 Valores médios do peso bruto (g) das latas dos néctares, em função do tempo de armazenamento

5 Valores médios do peso líquido (g) das latas dos néctares, em função do tempo de armazenamento

6 Valores médios dos teores de ácido ascórbico $(\mathrm{mg} / 100 \mathrm{~g})$ dos néctares, em função do tempo de armazenamento

7 Valores médios de acidez total titulável ( $\mathrm{g}$ ácido cítrico/100g) dos néctares, em função do tempo de armazenamento

8 Valores médios de $\mathrm{pH}$ dos néctares, em função do tempo de armazenamento

9 Valores médios de sólidos solúveis totais ( ${ }^{\circ}$ Brix) dos néctares, em função do tempo de armazenamento

10 Valores médios das análises sensoriais dos néctares, em função dos tratamentos 
11 Valores médios das análises sensoriais dos néctares, em função do tempo de armazenamento

12 Valores médios de vácuo (pol.Hg) das latas dos néctares light, em função do tempo de armazenamento

13 Valores médios do peso bruto (g) das latas dos néctares light, em função do tempo de armazenamento

14 Valores médios do peso líquido (g) das latas dos néctares light, em função do tempo de armazenamento

15 Valores médios dos teores de ácido ascórbico $(\mathrm{mg} / 100 \mathrm{~g})$ dos néctares light, em função do tempo de armazenamento

16 Valores médios de acidez total titulável ( $\mathrm{g}$ ácido cítrico/100g) dos néctares light, em função do tempo de armazenamento

17 Valores médios de $\mathrm{pH}$ dos néctares

light, em função do tempo de armazenamento

18 Valores médios de sólidos solúveis

( ${ }^{\circ}$ Brix) dos néctares light, em função

do tempo de armazenamento

19 Valores médios da análise sensorial dos néctares light, em função dos tratamentos

20 Valores médios da análise sensorial dos néctares light, em função do tempo de armazenamento 


\title{
PROCESSAMENTO E AVALIAÇÃO DA QUALIDADE DO NÉCTAR E NÉCTAR LIGHT DE DOIS CULTIVARES DE PÊSSEGO ADAPTADOS AO CLIMA SUBTROPICAL
}

\author{
Autora: Renata Basso Beisman \\ Orientador: Prof. Dr. João Nunes Nogueira
}

\section{RESUMO}

Foram analisadas as características físico-químicas dos pêssegos dos cultivares Aurora-1 e Dourado-2 e com estes, preparados néctar e néctar light. Os néctares foram submetidos a diferentes tratamentos (refrigeração, adição de sorbato de potássio e ácido ascórbico) e armazenados por 180 dias à temperatura ambiente, visando avaliar a qualidade dos cultivares para este tipo de processamento.

A qualidade da matéria-prima foi avaliada fisicamente em relação à textura, suculência e rendimento, e quimicamente em termos de $\mathrm{pH}$, sólidos solúveis totais, acidez total titulável e ácido ascórbico. As amostras dos néctares foram submetidos às análises físicas de vácuo, peso bruto e peso líquiido; análises químicas quanto aos teores de ácido 
ascórbico, acidez total titulável, $\mathrm{pH}$ e sólidos solúveis totais. As amostras dos néctares foram ainda avaliadas sensorialmente quanto à cor, consistência e sabor.

Os resultados mostraram que a refrigeração e a adição de sorbato de potássio foram eficientes na preservação da cor, consistência e sabor do néctar e néctar light de ambos cultivares, sendo considerandos os melhores tratamentos. O cultivar Dourado-2 apresentou características mais apropriadas para a obtenção do néctar e néctar light, mostrando-se superior ao cultivar Aurora-1 quanto à cor, consistência e sabor. 


\section{PROCESSING AND QUALITY EVALUATION OF NECTAR AND LIGHT NECTAR FROM TWO PEACH CULTIVARS ADAPTED TO SUBTROPICAL CLIMATE}

Author: Renata Basso Beisman Adviser: Prof. Dr. João Nunes Nogueira

\section{SUMMARY}

Physical and chemical characteristics of peach cultivars Aurora-1 and Dourado-2, were determined. Nectars from these cultivars were submitted to different treatments (refrigeration, addition of potassium sorbate and ascorbic acid) and stored for 180 days at room temperature.

Quality of raw material was evaluated regarding to texture, succulency, yield, $\mathrm{pH}$, soluble solids, titratable acidity and ascorbic acid. Nectars'samples were submitted to physical determinations for vacuum, gross weight and net weight; chemical analysis for ascorbic acid, titratable acidity, $\mathrm{pH}$, and soluble solids. Samples were also organoleptically evaluated for color, consistency and flavor. 
The results showed that refrigeration and addition of potassium sorbate were the most efficient treatments for preserving color, consistency and flavor of the nectars and light nectars from both cultivars and therefore are recommended. Dourado-2 presented better characteristics for nectar and light nectar processing being superior to Aurora-1 for all quality attributes evaluated. 


\section{INTRODUÇÃo}

O pessegueiro (Prunus persica L. Batsch), originário da China; atingiu a Europa através da Pérsia, hoje Irã. Chegou ao Brasil com Martim Afonso de Sousa, em 1532. As mudas que provinham da ilha da Madeira foram plantadas no planalto paulista (Gomes, 1982). É árvore frutífera típica de zona de clima temperado, da família das Rosáceas. Há séculos vem sendo cultivado no Oriente, na Europa e nas Américas, em latitudes elevadas (entre 30 e $50^{\circ}$ norte e sul) onde ocorrem, genericamente, de 500 até 2.000 horas anuais de frio abaixo de $7,2^{\circ} \mathrm{C}$. Ao ser introduzido em regiões de latitudes baixas, como $22 \pm 2^{\circ} \mathrm{S}$, o pessegueiro teve de ser adaptado ao clima subtropical-temperado predominante; nessas condições ecológicas, as temperaturas hibernais amenas impediam a adequada quebra de endodormência das gemas, e o conseqüente desenvolvimento vegetativo e reprodutivo das plantas (Barbosa, et al., 1997).

Com relação à exigência de frio, no Brasil, os novos cultivares do Instituto Agronômico de Campinas são mais tolerantes, sendo cultivares de qualidades organolépticas e agronômicas superiores, bem adaptados ao clima paulista (Penteado, 1997). Assim, esses cultivares têm sido amplamente aceitos pelos produtores e pelo público consumidor, servindo de base à evolução da persicultura no Estado (Barbosa, et al., 1997).

O pêssego é uma fruta considerada ótima quanto às suas qualidades nutritivas, apresentando: $51,50 \mathrm{Kcal} ; 3,43 \mathrm{~g}$ de glicídios; $0,41 \mathrm{~g}$ de proteínas; 
0,05g de lipídios; $375 \mathrm{mcg}$ de vitamina A; 0,95mg de vitamina B5 (niacina); $400 \mathrm{mcg}$ de vitamina B1 (tiamina); $65 \mathrm{mcg}$ de vitamina B2 (riboflavina); 26,80mg de vitamina $\mathrm{C}$ (ácido ascórbico); dentre os minerais destacam-se: potássio $121,30 \mathrm{mg}$, sódio $31 \mathrm{mg}$, fósforo $27 \mathrm{mg}$; cálcio $16 \mathrm{mg}$ e ferro $2,13 \mathrm{mg}$ (Franco, 1992).

A cultura do pessegueiro, na década de 60, obteve no Estado de São Paulo grande impulso, com a disponibilização de novos cultivares aclimatados às temperaturas de inverno ameno, típicas do planalto paulista (Barbosa et al., 1990). Na década de 70, o melhoramento do pessegueiro em São Paulo foi marcado pelas autofecundações e pelos cruzamentos controlados de cultivares nacionais e norte-americanas, de baixa exigência de frio, introduzidos da Flórida, em especial em 1969 (Barbosa et al., 1997). $\mathrm{Na}$ década de 80, o Instituto Agronômico de Campinas (IAC) dedicou esforço concentrado na obtenção de cultivares com características de maturação precoce e bem precoce e de frutas firmes e de epiderme avermelhada. Tal esforço se deveu à grande demanda por esses atributos, detectada entre os persicultores e comerciantes paulistas (Barbosa et al., 1997).

A cultura tem sazonalidade acentuada. Praticamente toda a oferta do pêssego de mesa concentra-se entre outubro e janeiro. No período de abril a agosto, a oferta no Entreposto Terminal de São Paulo da CEAGESP é pequena demais para permitir um levantamento de preços consistente, que reflita o preço real da fruta fresca. Isso impede a análise da sazonalidade dos preços do pêssego com base nos dados disponíveis do entreposto paulistano (FNP Consultoria \& Comércio, 1998).

O pêssego paulista amadurece naturalmente mais cedo que o produzido no Sul, e como a cultura em São Paulo é difundida em várias 
regiões, a época de maturação é ampla, normalmente se estendendo de setembro até fevereiro. Essa longa estação de pêssegos maduros é devida, também, ao cultivo de materiais selecionados. Os pomares paulistas localizam-se mais próximo dos principais centros industriais e de consumo, proporcionando vantagens em relação ao manuseio, transporte, conservação e comercialização da fruta e de seus produtos industrializados o que tem aumentado o consumo, resultando aos produtores maiores lucros, e possibilitando aprimorar ainda mais a cultura (Dall'Orto et al., 1984).

O mercado de fruta in natura tende a restringir-se cada vez mais aos produtores que conseguem fugir da concorrência direta do pêssego importado, beneficiando-se para tanto de condições especiais de microclima e da proximidade dos grandes centros consumidores. Para esses produtores, a lucratividade é considerada muito boa. Um produtor de bom nível tem custos de produção suficientemente baixos para garantir uma margem de lucro da ordem de $40 \%$, considerados sobre o preço de atacado e descontadas as despesas de pós-colheita e comercialização (FNP Consultoria \& Comércio, 1998).

O extenso território brasileiro, caracterizado por variadas condições climáticas e por distintos tipos de solos, apresenta uma produção agrícola extremamente diversificada, que confere ao país o título de principal produtor mundial em vários mercados (Carraro \& Cunha, 1994). O mercado de frutas representa em São Paulo importante segmento do setor agrícola e a produção de frutas para processamento industrial é crescente (Santiago et al., 1996).

Segundo a Legislação Brasileira, pode-se definir néctar de fruta como sendo um produto não fermentado, não gaseificado, destinado ao consumo 
direto, obtido pela dissolução em água potável de parte comestível da fruta (polpa e suco), adicionado de ácido e açúcares (Brasil, 1974).

A aceitação de alimentos processados por parte do consumidor depende principalmente da capacidade destes alimentos em atender as suas expectativas. Atributos organolépticos de qualidade tais como aparência, sabor e textura, o valor nutritivo e o custo determinam a aceitação ou rejeição dos alimentos, especialmente quando têm por finalidade a de parecer alimentos de consumo tradicional, ou ainda quando se pretende melhorar algumas características dos alimentos ditos tradicionais.

Dall'Orto et al. (1984) acreditam que pela aceitação crescente do pêssego industrializado no mercado interno e a possibilidade de exportação da fruta in natura, inclusive aos países tradicionalmente produtores, $\mathrm{e}$ também devido à diferentes épocas de maturação, há grandes possibilidades para produtos industrializados, destacando-se a polpa asséptica e o néctar.

$O$ néctar de frutas, embora seja um produto muito bom não é muito popular, principalmente, devido ao seu preço relativamente elevado no mercado (a embalagem encarece). Em outros países sua aceitação e consumo são grandes (Nogueira,1994).

O mercado dos produtos dietéticos vem consolidando-se como a grande tendência industrial da década, pois estes já fazem parte dos hábitos alimentares da sociedade moderna (Rodrigues, 1995). A partir dos anos 60 começaram a surgir os primeiros indícios de alternativas ao consumo do açúcar, visando inicialmente os diabéticos, obesos e hipertensos. Anos depois, preocupações com a forma física e com hábitos de vida mais saudáveis, colocaram em evidência o uso dos edulcorantes, que se consolidaram definitivamente na década de 80 e cujo mercado cresceu de maneira significativa (Stringuetto, 1991). 
A utilização de cultivares adaptados ao planalto paulista com adequadas características para a industrialização, complementada com o emprego de tecnologia simples e de baixo investimento, certamente permitirá a obtenção de néctar de pêssego de alta qualidade tornando o produto mais competitivo em nível nacional e internacional. 


\section{OBJETIVO}

Procurando contribuir para o estabelecimento de tecnologia apropriada, este trabalho tem por objetivo avaliar a qualidade de dois cultivares de pêssegos, adaptados ao planalto paulista, "Aurora-1" e "Dourado-2", para a obtenção de néctar e néctar light. A meta desta pesquisa é obter um produto de alta qualidade, que possa atender as exigências dos consumidores tanto em nível de consumo interno como para exportação. 


\section{REVISÃO DE LITERATURA}

\subsection{Considerações gerais}

Segundo Gava (1978), a industrialização dos produtos agropecuários pode contribuir consideravelmente para a melhoria da dieta de um país e do estado nutricional dos seus habitantes. A amplitude dessa contribuição depende de diversos fatores, como a existência de uma agricultura desenvolvida que possa receber uma tecnologia avançada, bem como o nível e poder aquisitivo da população.

No néctar, as frutas sem sementes, com ou sem casca, são despolpadas, peneiradas (purê) e adicionados de igual volume de xarope de sacarose (Brix variável de acordo com a fruta). Esse material após homogeneização, é acondicionado a quente em recipientes adequados que são então fechados hermeticamente, pasteurizados e resfriados (Nogueira, 1994).

Segundo o decreto estadual $n^{\circ} 12.486$, o néctar é definido como sendo o produto obtido pela mistura de $50 \%$, no mínimo, de suco e polpa integrais de frutas maduras, finamente divididos e tamisados (peneirados), água potável, sacarose, ácidos orgânicos e outras substâncias permitidas (São Paulo, 1978).

Suco de fruta, segundo a Legislação Brasileira (Brasil, 1974), é todo o produto obtido por extração de frutas maduras por processos tecnológicos adequados. Este suco, que leva o nome da fruta que lhe deu origem, pode ser classificado quanto à concentração ou quanto à forma de preservação. 
Martin (1969) descreve que néctar de frutas é fabricado a partir do purê, com adição de açúcar em proporções variáveis. Luh (1971), cita néctares de frutas enlatados como produtos obtidos da polpa desintegrada de uma ou várias frutas, com um ou mais adoçantes e outros ingredientes opcionais. Segundo Cruess (1973), néctar de frutas é o produto contendo não menos de $50 \%$ de suco puro, seja simples ou reconstituído de concentrados. Já Lopez (1975), relata que o termo "néctar de frutas" é usado na indústria para designar a mistura de suco e polpa de frutas com açúcar, que pode conter colorante artificial, aromatizante e ácido cítrico, para produzir um produto pronto para o consumo.

O Brasil atende aos requisitos para conquistar os consumidores de sucos e néctares, que são: ótima qualidade, sabor agradável, aroma, boa aparência de produtos, higiene, além de possuir todas as condições necessárias para se fixar como um grande produtor a nível mundial (Dayrell et al., 1992; Menezes, 1988 e Sucos..., 1989).

De acordo com Salomón et al. (1977b), os néctares de frutas tropicais, simples ou misturados, são produtos com grande aceitação em muitos países. Néctares como os de goiaba, mamão e manga constituem produtos de exportação em vários países como: Estados Unidos, Havaí e Índia. Enquanto no Brasil, o néctar foi introduzido com incerteza, ficando vários anos no esquecimento, aos poucos foi se restabelecendo e se firmando como um produto de ótimas perspectivas no mercado. Isto ocorreu devido ao novo hábito que o brasileiro adquiriu, em relação à aceitação de produtos líquidos de frutas prontos para o consumo (néctares e suco), coincidindo com o aumento do poder aquisitivo de boa parte da população. A presença de néctares de goiaba, pêssego e maracujá, principalmente, hoje comuns nos supermercados, vem confirmar essa nova fase antes ignorada. 
Para a industrialização é necessário adaptar e selecionar cultivares, empregar, quando necessário, armazenamento refrigerado, bem, como técnicas de processamento satisfatórias, a fim de que se possa oferecer ao mercado consumidor um produto que satisfaça a sua exigência, que é cada vez maior com o passar dos anos (Fonseca \& Nogueira, 1989).

Os pêssegos de cultivares adaptados para o planalto paulista apresentam diversas características desejáveis para industrialização (cor consistência, vitaminas, sólidos solúveis). A presença das vitaminas A e C leva ao consumo visando aspectos nutricionais da fruta. O cultivar "Aurora1 "apresenta quando maduro, teores de sólidos solúveis ( $\left.{ }^{\circ} \mathrm{Brix}\right)$ ao redor de 15, $\mathrm{pH}$ entre 3,9 e 4,8, cor amarelo-claro e polpa bastante firme (Ojima et al., 1987). O cultivar "Dourado-2" apresenta em sua fase madura, teores de sólidos solúveis ( ${ }^{\circ} \mathrm{Brix}$ ) ao redor de $15, \mathrm{pH}$ de 4,0 , coloração amarela, com tonalidade vermelho-escuro e textura firme (Ojima et al, 1985).

A conservação de sucos e néctares de frutas é basicamente determinada pelas condições que preservam as suas qualidades organolépticas (aroma, cor, sabor, consistência) e que previnem o desenvolvimento de microrganismos deteriorantes bem como a ocorrência de reações químicas ou enzímicas indesejáveis (Uboldi Eiroa, 1989).

Quanto à industrialização, o pêssego praticamente não apresenta problema com relação à textura, forma e a presença de enzimas que possam ocasionar o escurecimento da polpa durante o processamento.

Segundo Kato \& Martin ( 1978 ), a polpa de pêssego é o produto oriundo da parte comestível dessa fruta, podendo ser desintegrada e refinada, após descaroçamento (denominando-se neste caso também de purê) a qual é, em seguida, preservada por um processo físico ou químico específico. Sua utilização é quase sempre destinada como matéria-prima para a elaboração 
de suco, néctares, sorvetes, iogurtes, geléias, doces em massas e artigos de confeitaria em geral . Os mesmos autores afirmam que o sistema mais utilizado para a conservação do néctar é pela pasteurização e enchimento a $90^{\circ} \mathrm{C}$ ('hot fill') em latas ou em vidros, pois o $\mathrm{pH}$ baixo do produto (ao redor de 3,5 ), possibilita o uso dessa técnica. Comentam também, que a água utilizada no resfriamento deve ser clorada com 5ppm de cloro livre para prevenir problemas de contaminação através de microvazamentos.

De acordo com Manak (1977), o néctar de manga deve ser obtido pela diluição de $25 \%$ de polpa em xarope de açúcar. O produto deve ter um máximo de $15 \%$ de açúcar invertido, mínimo de $150 \mathrm{mmHg}$ de vácuo, espaço-livre menor que $12 \mathrm{~mm}, 12^{\circ} \mathrm{Brix}$, acidez máxima de $0,25 \%$ e apenas traços de metal.

Askar et al. (1996) prepararam polpa de pêssego mecanicamente e pasteurizada a $95^{\circ} \mathrm{C}$ por 60 segundos, usaram para preparo de néctar. Neste estudo o néctar apresentou-se com $17 \%$ de sólidos solúveis totais e 25 - 33\% de teor da fruta. Segundo Chitarra \& Chitarra (1990), o controle de qualidade de frutas, tanto dos produtos destinados ao consumo direto, como daqueles para o processamento, tem como objetivo a obtenção de produtos com qualidade padronizada e constante, visando, principalmente, as vantagens econômicas básicas (minimização de custos e maximização de rendimento pela prevenção de defeitos), observando-se também os critérios de segurança de uso desses produtos. Para tal, o controle deve abranger todo o ciclo de produção, incluindo o produto, o material de embalagem, condições de armazenamento e/ou processamento e comercialização. 


\subsection{Cultivares de pêssego}

A cultura do pessegueiro foi implantada utilizando-se mudas enxertadas, de preferência em cultivar resistente a nematóides (cv. Okinawa), e exige tratos culturais como irrigação nas estiagens, capinas, podas de inverno e verão, desbaste e ensacamento das frutas (opcional, para proteção contra as moscas-das-frutas).

Por ser uma fruteira típica de clima temperado os cultivares produzidos no Hemisfério Norte possuem exigência em horas de frio, que geralmente ultrapassam 800 horas. Em nossas condições, com raras exceções, elas não passam de 100 horas (Penteado, 1997). Entretanto com os melhoramentos genéticos, hoje em dia já existem cultivares próprios para regiões de clima mais quente, embora a necessidade de um período de frio ainda exista (Franco et al., 1983). Os cultivares atuais acham-se perfeitamente adaptados para produzir economicamente nas regiões subtropicais de inverno bem ameno, com 50-100 horas de frio, ou menos (Barbosa et al., 1997).

A seleção de cultivares mais apropriados para uma circunstância particular de produção é um fator muito importante. Muitos cultivares têm a capacidade de reter sua qualidade na fase pós-colheita devido às suas características genéticas, bioquímicas e fisiológicas endógenas, bem como a determinadas características físicas (Chitarra \& Chitarra, 1990).

A seleção de cultivares, a região de cultivo, as práticas culturais e o estádio de maturação na colheita, como também o manuseio do produto colhido são fatores importantes a serem considerados, uma vez que a matéria-prima é essencial para a qualidade e características do produto final (Paschoalino, 1989). Entre os diversos cultivares da mesma espécie de fruta ou hortaliça, existem grandes diferenças de sabor, cor, tamanho, forma, 
odor, textura, armazenamento, resistência a danos no transporte, nutrientes, resistência a moléstias, espessura da casca, tamanho e número de sementes, rendimento por área, época de maturação e outras propriedades, que irão afetar a adequação da fruta ou hortaliça para este ou aquele determinado método de conservação.

O cultivar "Aurora-1", originou-se da polinização aberta do pêssego 'Ouromel-3' em experimentos com plantas enxertadas, nas Extações Experimentais de Jundiaí e Monte Alegre do Sul, no período 1984-86, iniciando a distribuição de borbulhas no ano de 1986. Caracteriza-se por uma fruta médio (90 gramas), com sutura nítida, dividindo a fruta em duas partes assimétricas, pele com coloração de fundo amarela, com matiz vermelho intenso, cobrindo cerca de $70 \%$ da superfície. Apresenta polpa bastante firme, amarelo-clara, sabor bem agradável, acentuadamente doce e baixa acidez; teor de açúcares ao redor de $15^{\circ}$ Brix e $\mathrm{pH} 4,0-4,8$ (Ojima et al., 1987).

O cultivar "Dourado-2", originou-se do cruzamento dos cultivares 'Tutu x Maravilha', efetuado em 1976. Caracteriza-se por uma fruta graúdo (120 gramas), com sutura pouco nítida, pele de coloração amarela, com tonalidade vermelho-escura, polpa bem amarela, vistosa, de boa textura, firme e, ao mesmo tempo, sucolenta. Qualidade excelente, com sabor doceacidulado agradável: teor de açúcares ao redor de $15^{\circ} \mathrm{Brix}$ e $\mathrm{pH} 4,0$ (Ojima et al., 1985).

Qualquer que seja o método utilizado, a qualidade da matéria-prima não pode ser melhorada durante o processamento. Os vários métodos de processamento podem, no máximo, preservar as características que o produto possuía quando no estado fresco. Assim, a qualidade da matéria- 
prima é fator de fundamental importância no processamento de qualquer produto.

De acordo com Passos (1982), deve-se distinguir as exigências dos vários tipos de processamento para os quais o cultivar será utilizado. Visando a manutenção da forma, de interesse para congelação e confecção de compotas, há necessidade de uma textura rígida.

\subsection{Fatores que afetam a qualidade do pêssego}

\subsection{1. Ácido ascórbico}

A composição natural de um mesmo tipo de alimento pode variar muito com a procedência, cultivar, trato cultural etc. Além desta diferença natural, as vitaminas e os minerais podem ser perdidos nas várias etapas de produção, distribuição ou mesmo preparo doméstico de um alimento (Carvalho, 1995).

Reichcigl (1984) classifica o bom consumo de néctar pelo seu sabor agradável, e principalmente por ser um produto rico em vitamina C. Esta se degrada rapidamente em presença de cobre, ferro, oxigênio ou também em meio alcalino, além de ser termolábil.

Segundo Chitarra \& Chitarra (1990), cerca de 90\% das necessidades de vitamina $\mathrm{C}$ do ser humano advêm de frutas e hortaliças. Ela é o componente nutricional mais importante destes alimentos e as frutas cítricas são considerados como as melhores fontes, não só pelo teor dessa vitamina (50 a $75 \mathrm{mg} / 100 \mathrm{~mL}$ de suco) como pelo seu elevado consumo, nas dietas do mundo inteiro.

A vitamina $\mathrm{C}$ apresenta-se como um agente redutor, servindo como um índice de estabilidade de produtos elaborados de matéria-prima in natura. 
Durante o processamento, fatores como calor, luz, agentes oxidantes e $\mathrm{pH}$ contribuem para a diminuição dos níveis vitamínicos. O calor, utilizado geralmente para a alteração da estrutura dos tecidos de um alimento, destruição de microrganismos ou mesmo para a inativação de enzimas, pode alterar significativamente os teores de nutrientes, principalmente se sua utilização for acompanhada pela incorporação de ar (oxigênio) où água. Algumas vitaminas podem ser rapidamente degradadas, como a vitamina $\mathrm{C}$ (antioxidante natural), que é facilmente perdida em processos oxidativos (Carvalho, 1995).

Analisando vários trabalhos, Lourenço (1976) notou que diversos fatores afetam a estabilidade do ácido ascórbico em sucos de frutas, destacando-se a presença de enzimas oxidativas, de oxigênio, a pasteurização, a luz, a contaminação com metais pesados e a presença de dióxido de enxofre. Desta forma, a utilização de equipamentos de aço inoxidável, a desaeração e o tratamento com gases inertes são práticas recomendáveis, que contribuem para a manutenção de níveis aceitáveis de ácido ascórbico em alimentos processados.

Segundo Johnson (1995), a evidência de que os nutrientes oxidantes (vitamina $C$, vitamina $E$ e beta caroteno) são importantes para a saúde humana vem crescendo rapidamente. No processamento dos alimentos técnicas adequadas devem ser utilizadas, a fim de se obter melhor retenção destes nutrientes.

Várias propriedades destes componentes são importantes para os cientistas de alimentos, já que o gosto, por exemplo, é um importante atributo sensorial que pode afetar as características finais do sabor do alimento ao qual o nutriente é adicionado. As pessoas não consomem alimentos com sabor desagradável. O ácido ascórbico possui gosto ácido e a 
maioria dos alimentos enriquecidos com esta vitamina possui $\mathrm{pH}$ abaixo de 7.

Askar et al. (1996), estudando o processamento de néctar de pêssego observaram que o teor de ácido ascórbico decresceu e o teor de metais pesados aumentou ao longo do tempo de armazenamento. Essa observação de diminuição de ácido ascórbico no período de armazenamento foi também constatada por Aggarwal et al. (1992), analisando néctares de duas variedades de pêssegos. Embalagens contendo alumínio foram, de acordo com Wafa \& Rao (1989), adequadas para a preservação das características físico-químicas e sensoriais de néctar de pêssego. Suco e néctar de pêssego, conservados em embalagens de plástico com alumínio, preservaram as propriedades organolépticas após armazenamento, com mínimas alterações quanto ao escurecimento e decréscimo de vitamina C (Gherardi et al., 1972).

Diaz et al. (1987) determinaram o conteúdo de vitamina $\mathrm{C}$ em produtos dietéticos (sucos e néctares); nas amostras de suco o conteúdo de vitamina $\mathrm{C}$ ( $\mathrm{mg} / 100 \mathrm{~g}$ suco) foi de $46 \mathrm{em}$ laranja, 25 em abacaxi e $22 \mathrm{em}$ uva. No néctar (com adição de ácido ascórbico) o conteúdo de vitamina $\mathrm{C}$ (mg/100g néctar) foi de 80 em damasco, pêra e ameixa e 50 em pêssego e abacaxi.

A perda da qualidade nutricional durante o processamento e a estocagem de alimentos tem se tornado um problema crescente com a introdução dos regulamentos de classificação nutricional. Para aumentar o valor nutritivo de alimentos processados, muitos produtos são agora enriquecidos com vitaminas e minerais (Prado, 1994).

Parman \& Salinard (1967) citam que as perdas de vitamina C, em produtos processados de origem vegetal ocorrem devido à presença de oxigênio no meio e aos íons metálicos, tais como cobre, níquel e ferro, que 
catalisam a degradação do ácido ascórbico (processo oxidativo) em temperaturas ambientes elevadas, como as que apresentam os países de clima tropical e subtropical. A principal causa da degradação da vitamina $\mathrm{C}$ é a oxidação aeróbica ou escurecimento enzímico, ambas levando à formação de furaldeídos, compostos que polimerizam facilmente, com a formação de pigmentos escuros. É também rapidamente destruída pela luz. De modo geral, a estabilidade da vitamina $\mathrm{C}$ aumenta com o abaixamento da temperatura e a maior perda ocorre durante o aquecimento de alimentos, porém existem casos de perdas durante o congelamento, ou armazenamento de alimentos a baixas temperaturas (Bobbio \& Bobbio, 1989).

Segundo Figueiredo \& Uzelac (1976), o ácido ascórbico pode provocar escurecimento, transformando-se em ácido deidroascórbico com formação de odores estranhos. A ação enzímica tem influência considerável sobre a retenção do teor de ácido ascórbico em frutas e hortaliças. Quando a inativação enzímica é bem feita, a perda verificada pode ser insignificante (Hoffman, 1976).

Aradhita et al. (1995), estudando o escurecimento em néctar de goiaba, observaram que essa mudança de cor intensifica-se no decorrer do armazenamento à temperatura ambiente, devido provavelmente à rápida degradação do ácido ascórbico. As condições de armazenamento do néctar, independente da formulação, influenciam nas características da cor do produto, notando-se um escurecimento quando deixado por longos períodos à temperatura ambiente, porém este escurecimento não afeta a aceitabilidade do produto, porque, pela observação visual esse fenômeno praticamente não é notado (Salomón et al., 1977b).

Gofur et al. (1994), estudando a vida de prateleira e aceitabilidade de néctar de manga, verificaram que com exceção da vitamina $\mathrm{C}$ que diminuiu 
desde o começo do armazenamento, a acidez, o pH, os sólidos solúveis, fibras e os açúcares apresentaram mudanças insignificantes. Por outro lado, El Zoghbi \& Siliha (1992) observaram que em néctar dietético light de damasco o conteúdo de sólidos solúveis e açúcares não redutores diminuíram gradativamente com a adição de edulcorantes, e também destacaram que a acidez total não foi afetada embora o ácido ascórbico tenha diminuído em níveis de 70 - $80 \%$. Adicionando ácido ascórbico ao néctar de banana, Hernandez et al. (1976) não notaram diferenças quanto a cor, sabor e qualidade do produto.

De acordo com Andrade \& Camargo (1989), a indústria de alimentos pode utilizar os aditivos como recurso para compensar as perdas inevitáveis de nutrientes, mesmo após a escolha dos métodos mais adequados. São os aditivos nutricionais, que compreendem as vitaminas, proteínas, aminoácidos essenciais e minerais. Já o enriquecimento consiste em aumentar o nível nutricional já existente no produto.

\subsubsection{Cor e sabor}

A cor é um fator importante para avaliar a qualidade de um alimento. De fato, freqüentemente está ligado à maturação, presença ou não de impurezas, realização apropriada ou defeituosa de um tratamento tecnológico, condições de armazenamento, começo de deterioração por microrganismos etc. Por isso é que se baseiam na cor vários métodos oficiais para avaliar a qualidade dos alimentos (Cheftel et al., 1987).

A percepção do mundo ao nosso redor é dada pelos nossos sentidos. Destes o impacto visual é o mais importante, não sendo definido apenas pela forma e aspecto dos objetos, mas também pela cor. Dos três principais atributos de qualidade dos alimentos (cor, sabor e textura) a cor torna-se 
cada vez mais importante, à medida que os alimentos são expostos e vendidos (Ferreira, 1991).

O estudo da estabilidade da cor de produtos alimentícios tem grande importância, pois, quando se escolhe, seleciona ou simplesmente se observa um alimento qualquer, o impacto visual causado pela cor geralmente se sobrepõe ao causado pelos outros atributos e isto porque as cores os caracterizam sobremaneira, constituindo-se no primeiro critério aplicado para a sua aceitação ou rejeição. Isso porque se aceita ou não um alimento, em primeiro lugar com os olhos, ou seja, pela cor. Se a cor não for atraente, apesar da aparência (aspecto e forma) e odor, dificilmente o alimento será ingerido ou pelo menos provado (Ferreira, 1991).

Sabor é a soma das diversas sensações originais da estimulação dos receptores do gosto, olfato e as fibras nervosas que registram as sensações de tato e sensações químicas. Sabe-se que a cor dos alimentos influencia o sabor (Stillman, 1993).

Clydesdale (1993) mostrou que a cor afeta a percepção de outras características sensoriais, como sabor e aroma, afetando direta ou indiretamente a aceitabilidade e a preferência de alimentos e bebidas.

Askar et al. (1996) observaram o efeito do tipo de embalagem em função do tempo de armazenamento em néctar de pêssego, pasteurizado a $95^{\circ} \mathrm{C}$ por 60 segundos e acondicionados a quente em latas e garrafas de vidro, armazenado a $37^{\circ} \mathrm{C}$, por 12 meses. $\mathrm{O}$ tempo de armazenamento, a temperatura de estocagem, bem como o tipo de embalagem, apresentaram um pequeno efeito sobre os sólidos solúveis, acidez total e conteúdo de cálcio no néctar. Após seis meses de armazenamento, o néctar ficou inaceitável quanto à cor e sabor. $\mathrm{O}$ conteúdo de vitamina $\mathrm{C}$ diminuiu e o grau de descoloração aumentou com o tempo de armazenamento. A 
descoloração foi menor nas embalagens de metal (latas) do que nas garrafas de vidro.

Estudando néctar de mamão envasados em latas revestidas com estanho, Brekke et al. (1976) constataram que as amostras permaneceram inalteradas após 1 ano de armazenamento a $13^{\circ} \mathrm{C}$, e concluíram que o tipo de revestimento da embalagem não é fator limitante para conservação da qualidade do produto.

Gherardi et al. (1972), usando embalagens de plástico e plástico com alumínio para o armazenamento de suco e néctar de pêssego verificaram que a embalagem de plástico com alumínio preservou as propriedades organoléticas por 6 meses, porém a embalagem de plástico não permitiu armazenamento por mais de 2 meses.

Em trabalho com néctar de mamão, Payumo et al. (1968) verificaram que o armazenamento refrigerado $\left(4-5^{\circ} \mathrm{C}\right)$ permitiu a manutenção da cor do produto, a adição de ácido ascórbico produziu descoloração e a adição de metabissulfito de sódio não teve efeito na coloração final do néctar.

Khurdiya (1993) preparou néctares de manga em várias proporções e constatou que o produto preparado com igual proporção de sólidos solúveis totais e acidez titulável, apresentou-se com melhor cor, conteúdo de carotenóides, viscosidade e qualidades sensoriais.

Utilizando polpa congelada, Rodriguez et al. (1972) prepararam néctar de mamão com $15^{\circ}$ Brix e $\mathrm{pH} 3,7$ e observaram que o produto apresentou sabor agradável após 1 ano de armazenamento a $29^{\circ} \mathrm{C}$.

Salomón et al. (1977a), processando néctar misto de maracujá e mamão com $30^{\circ}$ Brix, concluíram que o néctar preparado na proporção 
17:25 (mamão/maracujá) foi o preferido e que o produto sofreu um pequeno escurecimento durante $o$ armazenamento.

Embora a cor não seja um componente nem do sabor nem da textura, é um dos fatores de maior importância na aceitação de um produto (Eskin, 1991).

\subsubsection{Corrosão da lata}

Corrosão é definida como sendo a deterioração de um metal por uma reação química ou eletroquímica (Anjos \& Anjos, 1985).

Em muitos produtos alimentícios enlatados, particularmente no caso de frutas de natureza ácida, a acidez é a causa primária da corrosão das latas, nos pontos em que estas apresentam falhas de envernizamento. Nessas falhas os ácidos orgânicos do produto enlatado, assim como o oxigênio retido no fechamento das latas, atuam e despolarizam os metais componentes do recipiente, com a formação de hidrogênio (Figueiredo, 1968).

Mahadeviah et al. (1975), trabalhando com néctar de manga, observaram que o grau de corrosão é inversamente proporcional à viscosidade do néctar. A corrosão foi maior em latas que continham polpa e néctar preparados com casca, e concluíram que a casca contém ácidos que aceleram a corrosão.

\subsection{Aditivos}

Além das substâncias e elementos químicos presentes de modo natural nas matérias-primas alimentícias, outros produtos, como os aditivos, podem ser incorporados às mesmas, direta ou indiretamente, durante 0 processamento, acondicionamento e transporte dos alimentos. Os aditivos de composição química conhecida e intencionalmente adicionados em 
quantidades pequenas e controladas, tem a finalidade de auxiliar o processo tecnológico, melhorar a qualidade organoléptica e aumentar o tempo de conservação dos produtos (Pavanello, 1990). No Brasil, o Ministério da Saúde, através da Comissão Nacional de Normas e Padrões para Alimentos (CNNPA), define um aditivo como a "substância ou mistura de substâncias, dotada ou não de valor nutritivo, adicionada ao alimento com a finalidade de impedir alterações, manter, conferir e/ou intensificar seu aroma, cor e sabor, modificar ou manter seu estado físico geral ou exercer qualquer ação exigida para uma boa tecnologia de fabricação do alimento" (Volpi, 1985).

De acordo com Toledo (1986), o advento do uso de aditivos em alimentos no começo deste século, trouxe à sociedade benefícios inegáveis, traduzidos principalmente no aumento de produção e disponibilidade de alimentos, na melhoria de suas propriedades funcionais e sensoriais, bem como numa diminuição de custos. Porém, o seu emprego em alimentos somente é permitido após a consideração de diversos fatores que incluem a necessidade tecnológica do aditivo e, principalmente, o estabelecimento de sua segurança.

De acordo com Nazário (1988), desde que se respeitem os limites estabelecidos pela legislação, todos os aditivos alimentícios, sem exceção, são inofensivos à saúde. Da mesma forma, é importante frisar que qualquer substância que compõe uma dieta alimentar, seja de origem natural ou não, poderá provocar prejuízos à saúde se ingerida em quantidades excessivas. Assim, conclui-se que tudo o que consumimos em excesso pode ser tóxico ou provocar danos ao organismo, mesmo em se tratando de produtos de consumo diário, com os quais já estamos habituados.

Segundo Alves \& Garcia (1993) e Uboldi Eiroa (1989), a conservação dos sucos e néctares de frutas é determinada, primeiramente, pela prevenção 
do desenvolvimento de microrganismos deteriorantes e pela inibição da ação de enzimas naturais, o que é obtido por meio do tratamento térmico a que é submetido o produto e/ou pelo uso de conservantes químicos ou comercialização sob refrigeração / congelação.

Os aditivos, quando empregados intencionalmente e dentro das especificações preconizadas pela legislação, aumentam o valor nutritivo, o tempo de conservação e a estabilidade, padronizam a qualidade e tornam o alimento mais atraente ao consumidor (Angelucci, 1989c).

Dentre as classes funcionais de aditivos alimentares utilizados em bebidas, duas se destacam particularmente, que são os acidulantes e os conservantes. Para que seja aprovado um conservante químico a ser utilizado em alimentos para consumo humano, inúmeros estudos são realizados por especialistas da Organização Mundial da Saúde (Almeida, 1996b).

De acordo com Leitão et al. (1977), o uso de conservantes é bastante comum em nossas condições, destacando-se o ácido benzóico ou seus sais de sódio e potássio, o ácido sórbico ou sorbatos e compostos de enxofre. A concentração máxima desses conservantes é controlada pela Legislação, sendo importante destacar que a eficiência do tratamento depende de inúmeros fatores, principalmente concentração, temperatura do alimento, tipo e grau de contaminação presente e $\mathrm{pH}$ do produto.

A Legislação Brasileira que regulamenta o uso de aditivos em alimentos, permite o emprego do ácido benzóico e seus sais como conservantes em néctares e sucos de frutas, no teor máximo de $0,1 \%$ (Brasil, 1988a). 


\subsection{1. Ácido ascórbico}

$\mathrm{O}$ ácido ascórbico é um agente redutor, prestando-se portanto ao uso como antioxidante. Em polpas, suco de frutas, refrescos, entre outros, o ácido ascórbico pode ser adicionado até o teor máximo de $0,03 \%$. Exerce ação protetora de componentes do sabor, evitando ação oxidativa do oxigênio durante armazenamento e distribuição. A oxidação não enzímica em sucos de frutas enlatados ou engarrafados pode ser retardada pela adição de 50mg de ácido ascórbico por litro. A proteção de carotenóides naturais presentes em alguns sucos também pode ser obtida pela adição de ácido ascórbico, bem como as modificações de cor e sabor que podem ocorrer durante a pasteurização de sucos de frutas podem ser evitadas ou, pelo menos, amenizadas (Antunes \& Canhos, 1982 ): Segundo Ramana et al. (1984), o ácido ascórbico tem a capacidade de preservar a cor, sabor e aroma do néctar durante o armazenamento do produto.

Os tratamentos a que os alimentos são submetidos durante a elaboração e preparação podem causar uma série de modificações em sua composição, que podem afetar tanto as propriedades nutritivas como organolépticas. $\mathrm{O}$ ácido ascórbico pode sofrer importantes perdas durante o processamento. Por ser uma vitamina termolábel e hidrosolúvel, ela é facilmente destruída durante o processamento (Cid et al., 1990).

\subsection{2. Ácido cítrico}

$\mathrm{O}$ ácido cítrico é um aditivo com função de acidulante. $\mathrm{O}$ acidulante é uma substância capaz de comunicar ou intensificar o sabor dos alimentos. $O$ grau de acidez é muito importante nas propriedades dos diversos alimentos como refrigerantes, suco de frutas, entre outros. Esses agem através da 
redução do $\mathrm{pH}$, minimizando o crescimento microbiano e melhorando o efeito dos conservantes. $O$ limite máximo de aplicação em produtos de frutas é de 0,20\% (Antunes \& Canhos, 1982).

Bernhardt (1974) estudou a adição de ácido cítrico na confecção de bananada e goiabada a partir de suas polpas e observou que a quantidade de ácido cítrico ( $\mathrm{g} / \mathrm{kg}$ ) necessária para abaixar o $\mathrm{pH}$ a 3,7 da polpa de goiaba $\mathrm{e}$ de banana foram respectivamente 5,3 e 6,2 e para $\mathrm{pH} 3,5$ respectivamente 9,5 e 10,0 .

O ácido cítrico foi utilizado em todos os tratamentos.

\subsubsection{Sorbato de potássio}

No néctar de pêssego este é um aditivo com função de conservante. Conservantes são substâncias que impedem ou retardam a alteração dos alimentos por microrganismos. O limite máximo permitido de sorbato de potássio em sucos e néctares é de 0,10\% (Antunes \& Canhos, 1982).

Os sorbatos estão entre os antimicrobianos mais eficazes na conservação de alimentos. $O$ ácido sórbico é um ácido graxo que é metabolizado na mesma maneira que outros ácidos graxos de alimentos.

A eficácia do sorbato de potássio aumenta com maior acidez, sendo bastante solúvel $\left(139 \mathrm{~g} / 100 \mathrm{~mL} \mathrm{H}_{2} \mathrm{O}\right.$ a $\left.20^{\circ} \mathrm{C}\right)$. Acima de $\mathrm{pH} 4,0$, o sorbato é mais eficaz do que benzoato de sódio e propionato de sódio ou cálcio. A adição do sorbato de potássio em produtos processados deve ser feita após o tratamento térmico, evitando-se perdas (Araújo, 1990).

De ação eficaz contra a maioria dos microrganismos (fungos, leveduras ou bactérias) causadores da deterioração de alimentos, o ácido sórbico é inofensivo ao homem, sendo decomposto pelo organismo humano como ácido graxo alimentar. Quando empregado corretamente, o ácido 
sórbico não afeta o aroma e nem o sabor dos alimentos. O sorbato de potássio, ao ser adicionado aos alimentos, libera o seu componente de ação conservadora, que é o ácido sórbico (Ácido sórbico, 1979).

O ácido sórbico é o único ácido orgânico insaturado produzido sinteticamente, permitido como conservante em alimentos. Em face de sua característica neutra no sabor, é recomendável para uso em sucos e bebidas, em contraste com os benzoatos, que alteram o sabor. É eficiente no controle de fungos e leveduras e pouco eficientes no controle de bactérias, e ligeiramente solúvel em água $\left(0,16 \mathrm{~g} / 100 \mathrm{~mL} \mathrm{H}_{2} \mathrm{O}\right) . \mathrm{O} \mathrm{pH}$ ótimo de atuação estende-se até 6,0 .

\subsection{Produtos dietéticos}

Pela portaria que rege as leis da alimentação, consideram-se "alimentos dietéticos" ou "de regime" ou "alimentos para dietas especiais", os alimentos e as bebidas especialmente elaborados e formulados, quer pela escolha de seus ingredientes, quer pela substituição, adição ou supressão parcial ou total de um ou mais de seus componentes, de forma que sua composição atenda às necessidades dietéticas específicas de pessoas com exigências metabólicas, físiológicas ou físicas, particulares (Costa, 1995b).

Para a Associação Brasileira da Indústria de Alimentos Dietéticos (ABIAD), diet é conceituado como alimentos ou bebidas especialmente elaborados e formulados, quer pela escolha adequada de seus ingredientes, quer pela substituição, adição ou supressão parcial ou total de um ou mais de seus componentes, de forma que a sua composição atenda necessidades dietéticas específicas, de pessoas com exigências metabólicas, fisiológicas ou físicas particulares. Para a ABIAD,1992; o alimento diet apresenta 
redução calórica total na ordem de $65 \%$ em relação ao produto similar usual, não podendo conter açúcar adicionado.

Alimento light é aquele onde foi diminuído ou abrandado o teor de um ou mais componentes, implicando em uma pequena redução calórica, porém sem destinação específica a nenhum tipo de dieta. Esta redução não deverá extrapolar 35\% do valor calórico de um dos elementos que entram em sua composição, o que não o caracteriza como um alimento dietético (ABIAD, 1992). Porém, mesmo sendo diet ou light, o alimento pode ser altamente calórico (Amoedo, 1997).

Belo (1995) e Costa (1995b) ressaltam que os produtos dietéticos também não devem ser consumidos à vontade pelos diabéticos, pois doces, certas bebidas e outros produtos à base de frutas, contêm os carboidratos naturais da própria fruta.

Enquanto os produtos diet tem uma indicação específica, os light não tem. Os alimentos light são aqueles modificados do convencional com redução mínima de $25 \%$ de calorias. Todos os light tendem a ter menos teor de açúcar e gordura. Normalmente os alimentos light são consumidos por pessoas que não tem uma patologia específica. São pessoas saudáveis e que estão buscando produtos de melhor qualidade nutritiva (Brasil, 1995).

Os chamados produtos dietéticos têm revolucionado o mercado alimentício e conquistado consumidores diabéticos, obesos, pessoas com distúrbios orgânicos e um grande número de pessoas saudáveis, preocupadas com a saúde e a boa forma física. Esse crescimento explosivo aconteceu a partir de 1988, com as modificações na Legislação Brasileira que passou a considerar os dietéticos como alimentos e não mais como remédio, como eram então chamados. Segundo a Associação Brasileira da Indústria de Alimentos Dietéticos (ABIAD), o público consumidor atualmente, chega à 
casa dos 30 milhões de pessoas, sendo cerca de 10 milhões o número de produtos dietéticos existentes no país (Arêas, 1991 e Menezes \& Viegas, 1990).

\subsubsection{Edulcorantes}

Edulcorantes são aditivos alimentares, definidos como substâncias orgânicas não glicídicas, capazes de conferir gosto doce aos alimentos (Muradian \& Penteado, 1990).

São compostos de sabor extremamente doce, não necessariamente açúcares ou polióis, embora possam contê-los como parte de suas moléculas e não necessariamente energéticos, com poder edulcorante muito superior ao da sacarose (Angelucci, 1989a).

Segundo Almeida (1996a), o avanço científico e tecnológico sobre edulcorantes, sua aplicação em muitos alimentos, liberação para uso em bebidas, tanto por parte dos países menos desenvolvidos como pelas grandes potências, somadas à preocupação das pessoas com a estética e, principalmente, uma representativa parcela da sociedade brasileira que, por ordem médica, tem que ter rigoroso controle de açúcar, como os obesos e os diabéticos, proporcionaram uma Legislação específica para bebidas dietéticas.

Assim sendo as bebidas dietéticas são definidas como " bebidas não alcoólicas, destinadas a complementar dietas especiais, apresentando características semelhantes às bebidas convencionais, onde o açúcar seja substituído integralmente por edulcorantes “. Os edulcorantes permitidos podem ser calóricos ou não calóricos, artificiais ou naturais. $\mathrm{Na}$ rotulagem das bebidas dietéticas aprovadas na portaria, além das informações exigidas, 
deve constar a expressão contém fenilalanina, quando na bebida contiver o aspartame como edulcorante (Almeida, 1996a).

O emprego de edulcorantes na indústria de alimentos encontra inteira justificativa nos produtos destinados a consumidores que necessitam de restrição calórica em suas dietas, bem como para aqueles portadores de diabete (Antunes \& Canhos, 1982). E segundo Muradian \& Penteado (1990), os edulcorantes também ajudam a diminuir a incidência de cárie dental e substituem o açúcar quando este não estiver disponível no mercado.

De acordo com a Legislação Brasileira (Brasil, 1988), os edulcorantes permitidos podem ser calóricos ou não e artificiais (sacarina, ciclamato, acessulfame $\mathrm{K}$ e aspartame) ou naturais (esteviosídeo, sorbitol e manitol).

a) Aspartame $\left(\mathrm{C}_{14} \mathrm{H}_{8} \mathrm{~N}_{2} \mathrm{O}_{5}\right)$ : É um edulcorante de natureza protéica, composto pelos aminoácidos ácido aspártico e fenilalanina, ambos encontrados naturalmente nos alimentos, e por metanol.

Apresenta uma doçura de característica muito parecida à do açúcar, não apresentando gosto residual e é usado atualmente em mais de $5 \mathrm{mil}$ produtos, desde bebidas e produtos de confeitaria até produtos farmacêuticos (Aspartame, b).

Seu poder edulcorante é cerca de 180-200 vezes mais doce do que a sacarose. A intensidade de doçura depende do alimento variando de 170 a 230 vezes (Aspartame, a).

Apesar deste edulcorante ser isocalórico com a sacarose (peso/peso), ele pode provocar uma redução drástica nas calorias de várias formulações por causa da sua intensa doçura.

Em particular, o aspartame em bebidas realça o sabor da fruta e possibilita a redução do custo final. O conteúdo calórico de $4 \mathrm{Kcal} / \mathrm{g}$ e o processo de digestão, assimilação e metabolismo do aspartame são similares 
ao das proteínas dos alimentos comuns. $\mathrm{O}$ aspartame misturado com o sorbitol apresenta a propriedade de aditivo, intensificando as características do produto (Aspartame, c).

O aspartame não é cariogênico e não possui sódio na sua composição, o que o torna recomendável para pacientes portadores de hipertensão. Tem como benefício adicional a capacidade de aumentar a sensação de saciedade (Costa, 1995a).

Não há quantidade de aspartame recomendado para o uso humano, visto ser, esta substância, considerada como aditivo alimentar e não como droga. Entretanto, a FDA, Food and Drug Administration definiu a ingestão diária aceitável (IDA) considerada como segura, para a população sadia normal, baseada nos padrões atuais de uso e nos efeitos colaterais observados.

A ingestão diária aceitável, atualmente, é de $50 \mathrm{mg} / \mathrm{kg} / \mathrm{dia}$, equivalente a 7 litros de refrigerante, no adulto (Caballero et al, 1986).

b) Sorbitol : É um poliol obtido a partir da hidrogenação catalítica de açúcares. O mais importante dos açúcares-álcoois, foi isolado pela primeira vez das cerejas de Sorbus aucuparia.

O sorbitol é estável numa ampla faixa de $\mathrm{pH}$ e não sofre alterações quando submetido às temperaturas normalmente utilizadas nos processos de produção de alimentos (Soler, 1991).

Segundo Nabors \& Gelardi (1986), o sorbitol é comercialmente produzido pela hidrogenação da dextrose conforme esquema a seguir: 


\begin{tabular}{cccc}
$\mathrm{COH}$ & \multicolumn{1}{c}{$\mathrm{CH}_{2} \mathrm{OH}$} \\
$\mathrm{H}-\mathrm{C}-\mathrm{OH}$ & $\mathrm{H}-\mathrm{C}-\mathrm{OH}$ \\
$\mathrm{HO}-\mathrm{C}-\mathrm{H}$ & $+\mathrm{H}_{2} \longrightarrow \mathrm{HO}-\mathrm{C}-\mathrm{H}$ \\
$\mathrm{H}-\mathrm{C}-\mathrm{OH}$ & & $\mathrm{H}-\mathrm{C}-\mathrm{OH}$ \\
$\mathrm{H}-\mathrm{C}-\mathrm{OH}$ & & $\mathrm{H}-\mathrm{C}-\mathrm{OH}$ \\
$\mathrm{CH}_{2} \mathrm{OH}$ & (Dextrose) & $\mathrm{CH}_{2} \mathrm{OH} \quad$ (Sorbitol)
\end{tabular}

É o poliol mais encontrado na natureza (maçã, pêssego, pêra, ameixa, entre outras). Sua absorção pelo intestino delgado, por difusão passiva, é lenta até ser metabolizado no fígado. Não se deve ingerir doses elevadas, pois devido a absorção lenta, os polióis podem alcançar o intestino grosso e provocar diarréia osmótica. Os níveis tolerados, por dia, após adaptação, variam de 15 a 20 gramas (Sivieri, 1997).

Seu poder edulcorante em relação a sacarose é de 0,5 a 0,7 e seu IDA (ingestão diária aceitável) ainda não foi determinada (Almeida, 1996a).

É calórico, sendo considerado mais como veículo do que adoçante, isto é, permite que o alimento ganhe corpo, característica normalmente obtida com o uso do açúcar. Apresenta um teor de $4 \mathrm{Kcal} / \mathrm{g}$ (Angelucci, 1989b).

A característica principal deste edulcorante é de dar 'corpo' à bebida (Aguiar et al., 1987 e Almeida, 1996a). Além de sua aplicação em dietas alimentares especiais, o sorbitol também é utilizado como umectante, estabilizante e sequestrante de alguns metais multivalentes (Dwivedi, 1986).

Gava (1987) afirma que, à medida que a humanidade aumenta seus conhecimentos sobre gosto, segurança, tecnologia e, à medida que novos edulcorantes são aprovados, o conceito do uso combinado de edulcorantes é 
o que se aproxima do edulcorante não calórico ideal, que nos proverá de infindável possibilidades de emprego em produtos alimentícios. 


\section{MATERIAL E MÉTODOS}

As atividades desta pesquisa foram realizadas no Setor de Processamento de Alimentos do Departamento de Agroindústria, Alimentos e Nutrição da Escola Superior de Agricultura "Luiz de Queiroz" Universidade de São Paulo, em Piracicaba.

\subsection{Matéria - prima}

Os pêssegos "Aurora-1" e "Dourado-2" utilizados neste trabalho de pesquisa foram obtidos no município de Itupeva - Estado de São Paulo. As frutas foram colhidas quando atingiram o ponto comercial adequado (totalmente desenvolvidos e fisiologicamente amadurecidos), sendo em seguida transportadas para a unidade de processamento.

\subsection{Caracterização da matéria - prima}

\subsubsection{Análise física}

a) Textura: Para as determinações da textura das frutas foi utilizado o "Texture Testing System" (texturômetro), modelo TP-1, acoplado a um registrador automático de variações de força, operando com célula-padrão de cisalhamento e compressão CS-1, com 10 lâminas de $1 / 8$ polegadas de espessura e ângulo de $90^{\circ}$. $\mathrm{O}$ instrumento foi provido de um anel de prova de $3000 \mathrm{lbf}$ sendo a velocidade de descida do pistão de $20 \mathrm{~cm} / \mathrm{min}$. 
As amostras foram previamente pesadas $(80 \mathrm{~g}$ de pêssego inteiros sem caroço) e colocadas ao acaso na célula-teste. Os resultados são expressos em libra força por grama de amostra (lbf/g de amostra).

b) Rendimento: Para as determinações de rendimento da matériaprima, foram utilizadas amostras de $1000 \mathrm{~g}$ de frutas, tomadas aleatoriamente dos lotes do material.

Inicialmente, os pêssegos foram pesados em balança semi-analítica; a seguir foram limpos, lavados em água corrente e drenados por 15 minutos, sendo então novamente pesados e a seguir descaroçados e transformados em purê em despolpadeira Bonina 0,25df, utilizando a peneira de $0,6 \mathrm{~mm}$. Os resultados são expressos em porcentagem do peso de purê pronto para o processamento em relação ao peso original da matéria-prima.

\subsubsection{Análise química}

a) $\mathrm{pH}$ : Foi determinado em potenciômetro modelo PA-200. Os resultados são expressos em unidade de $\mathrm{pH}$ (Pregnolatto \& Pregnolatto, 1985).

b) Acidez total titulável: Na determinação da acidez total titulável, amostras de $10 \mathrm{~g}$ foram trituradas (em processador elétrico) e homogeneizadas com $90 \mathrm{ml}$ de água destilada e, a seguir, tituladas rapidamente sob agitação, com solução $0,1 \mathrm{~N}$ de hidróxido de sódio $(\mathrm{NaOH})$ padronizado, até coloração rósea tendo como indicador a fenolftaleína $1 \%$, de acordo com Kanesiro et al. (1982) e Pregnolatto \& Pregnolatto, (1985).

Segundo método de referência número 22060 da "Association of Official Analytical Chemists"- AOAC (1985), os resultados devem ser expressos em porcentagem de ácido presente em maior quantidade na matéria-prima. Assim sendo, os resultados de acidez foram expressos em 
gramas de ácido cítrico por 100 gramas de polpa de pêssego, por se tratar do ácido presente em maior quantidade em pêssego.

c) Sólidos solúveis totais: Foram determinados os teores de sólidos solúveis totais, utilizado-se o refratômetro Atago, modelo N-1, homogeneizando-se a amostra e transferindo de 1 a 2 gotas para o prisma do refratômetro, desprezando-se partículas grandes de polpa; os resultados foram expressos em ${ }^{\circ}$ Brix (Tressler \& Joslyn, 1961 e Pregnolatto \& Pregnolatto, 1985).

d) Ácido ascórbico: foi determinado pesando-se $10 \mathrm{~g}$ de polpa triturada e homogeneizada e diluindo-se em $90 \mathrm{ml}$ de ácido oxálico 0,4\%. Após agitação para homogeneização, foi tomada uma alíquota de $2 \mathrm{ml}$ que foi titulada com Reativo de Tillmans ( 2,6 diclorofenol-indofenol ), até obter uma coloração ligeiramente rosada e estável por 15 segundos. Os resultados foram expressos em $\mathrm{mg}$ de ácido ascórbico por $100 \mathrm{~g}$ de polpa de pêssego (Ranganna, 1977 e Pregnolatto \& Pregnolatto, 1985).

Todas as análises físicas e químicas foram efetuadas com duas repetições, utilizando-se amostras tomadas ao acaso dos lotes dos dois cultivares de pêssego.

\subsection{Processamento dos pêssegos}

As operações utilizadas no processamento dos pêssegos estão esquematizadas na Figura 1.

Após o recebimento dos lotes de pêssego no laboratório, as frutas foram selecionadas, lavadas e drenadas. Foram submetidas ao branqueamento (água fervente) por 15 minutos e em seguida as frutas tiveram seus caroços retirados, as polpas cortadas e trituradas em despolpadeira marca Bonina $0,25 \mathrm{df}$, utilizando a peneira de $0,6 \mathrm{~mm}$ para a 


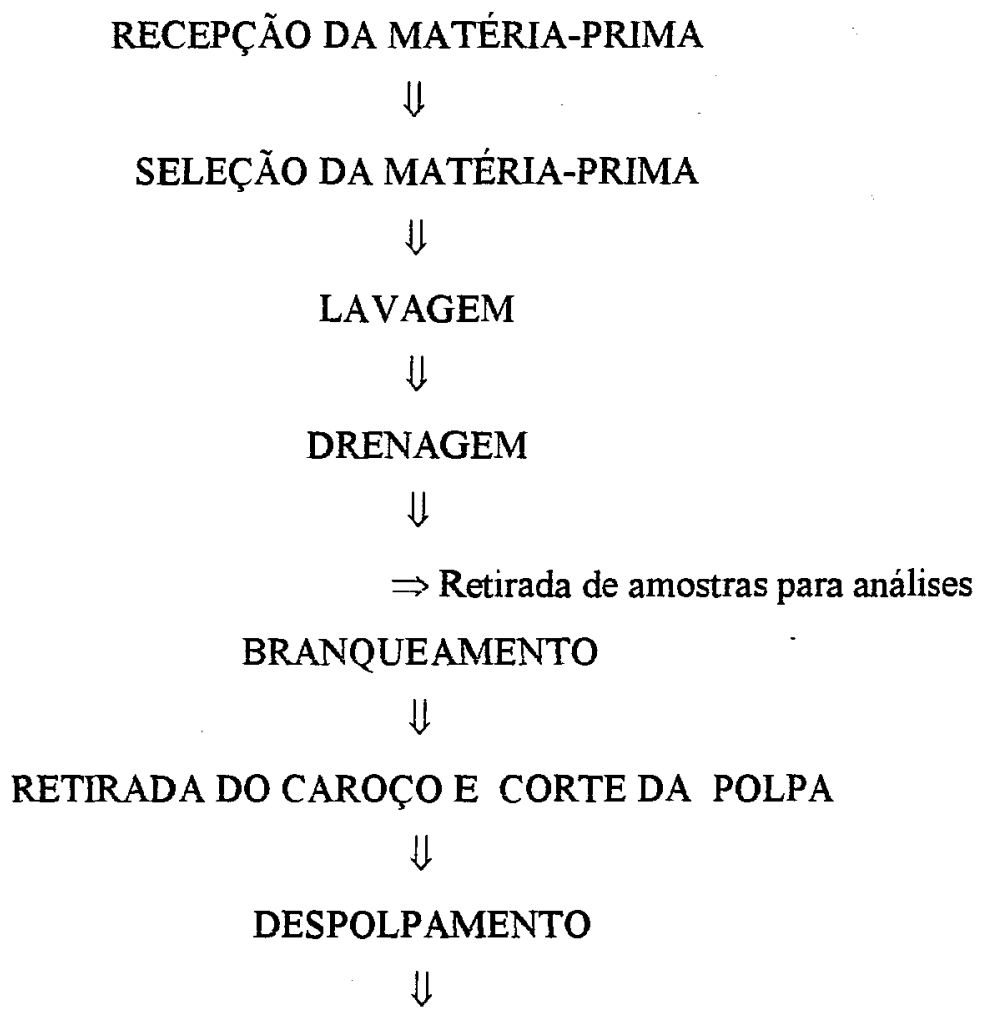

ADIÇÃO DO XAROPE DE SACAROSE E/OU EDULCORANTES $\Downarrow$ HOMOGENEIZAÇÃO $\Downarrow$ ACIDIFICAÇÃO E APLICAÇÃO DOS TRATAMENTOS $\Downarrow$ PASTEURIZAÇÃO A $90^{\circ} \mathrm{C}$ ( 15 SEG )

$\Downarrow$ ACONDICIONAMENTO À QUENTE $\left(90^{\circ} \mathrm{C}\right)$ $\Downarrow$ RECRAVAÇÃO, RESFRIAMENTO E ARMAZENAMENTO À TEMPERATURA AMBIENTE OU REFRIGERADO

Figura 1 - Fluxograma do processamento utilizado para a produção do néctar de pêssego. 
obtenção do purê o qual foi misturado manualmente ao xarope de sacarose.

\subsubsection{Néctar}

O néctar elaborado consistiu da mistura, em peso, de 50 partes de purê e 50 partes de xarope de sacarose com ${ }^{\circ}$ Brix suficiente para se obter o néctar com Brix de equilíbrio ao redor de $13^{\circ}$. Com a aplicação de calor durante a pasteurização, ocorre uma pequena concentração entre a sacarose das frutas, ocasionando uma elevação no teor de sólidos solúveis do néctar (de $13^{\circ}$ para $14^{\circ}$ Brix). A seguir, o néctar foi homogeneizado, acidificado, submetido os tratamentos e pasteurizado por aquecimento em imersão em água sob vapor, em recipientes de aço inox, até atingir a temperatura de $90^{\circ} \mathrm{C}$, estando assim, pronto para o acondicionamento em latas, recravação, resfriamento a temperatura ambiente e armazenamento refrigerado e ao ambiente.

O néctar dos dois cultivares de pêssego apresentou os seguintes valores centesimais: $72,67 \mathrm{Kcal}$ e $18,26 \mathrm{~g}$ de açúcar $(14,83 \mathrm{~g}$ adicionado + $3,43 \mathrm{~g}$ da fruta).

Os tratamentos aplicados estão esquematizados na Figura 2.

A) Tratamentos para a obtenção do néctar

\section{Tratamento 1 (Testemunha): Purê de pêssego + xarope de sacarose +} ácido cítrico

Após o preparo e despolpamento das frutas, um lote de $2900 \mathrm{~g}$ de purê de pêssego a $10,72^{\circ}$ Brix (cultivar Dourado-2) e outro lote de mesmo peso a 9,47 ${ }^{\circ}$ Brix (cultivar Aurora-1) foram misturados, respectivamente, com $2900 \mathrm{~g}$ de xarope de sacarose a $15,28^{\circ}$ Brix (cultivar Dourado-2) e $2900 \mathrm{~g}$ do xarope a $16,53^{\circ}$ Brix (cultivar Aurora-1), a fim de se obter o néctar, de cada 


\begin{tabular}{|c|c|c|c|}
\hline \multicolumn{4}{|c|}{$\begin{array}{c}\text { CULTIVAR } \\
\downarrow \\
\text { NECTAR } \\
\downarrow\end{array}$} \\
\hline 1 & 2 & 3 & 4 \\
\hline $\begin{array}{l}\text { purê de } \\
\text { pêssego }\end{array}$ & $\begin{array}{l}\text { purê de } \\
\text { pêssego }\end{array}$ & $\begin{array}{l}\text { purê de } \\
\text { pêssego }\end{array}$ & $\begin{array}{l}\text { purê de } \\
\text { pêssego }\end{array}$ \\
\hline+ & + & + & + \\
\hline $\begin{array}{l}\text { xarope de } \\
\text { sacarose }\end{array}$ & $\begin{array}{c}\text { xarope de } \\
\text { sacarose }\end{array}$ & $\begin{array}{c}\text { xarope de } \\
\text { sacarose }\end{array}$ & $\begin{array}{c}\text { xarope de } \\
\text { sacarose }\end{array}$ \\
\hline+ & + & + & + \\
\hline ácido cítrico & ácido cítrico & $\begin{array}{c}\text { ácido cítrico } \\
+\end{array}$ & $\begin{array}{c}\text { ácido cítrico } \\
+\end{array}$ \\
\hline & $\begin{array}{c}\text { refrigeração } \\
\left(5-6^{\circ} \mathrm{C}\right)\end{array}$ & $\begin{array}{c}\text { sorbato de } \\
\text { potássio }\end{array}$ & $\begin{array}{c}\text { sorbato de } \\
\text { potássio } \\
+ \\
\text { ácido ascórbico }\end{array}$ \\
\hline
\end{tabular}

Figura 2 - Esquema dos tratamentos aplicados ao purê de pêssego para obtenção de néctar.

cultivar, a $14^{\circ}$ Brix (selecionado em testes preliminares). A seguir, com adição de ácido cítrico em quantidade suficiente para reduzir o $\mathrm{pH}$ do néctar inicialmente de 4,2 (cultivar Aurora-1) e de 3,75 (cultivar Dourado-2) para o valor próximo de 3,5 (Brasil, 1988b).

As amostras deste tratamento foram armazenadas à temperatura ambiente.

\section{Tratamento 2: Purê de pêssego + xarope de sacarose + ácido cítrico + refrigeracão}

Este tratamento seguiu o mesmo procedimento que o anterior (Tratamento 1), porém, as amostras foram armazenadas à temperatura de refrigeração $\left(5-6^{\circ} \mathrm{C}\right)$. 


\section{Tratamento 3: Purê de pêssego + xarope de sacarose + ácido cítrico + sorbato de potássio}

Este tratamento seguiu o mesmo procedimento do Tratamento 1, porém, com adição de $0,1 \%$ de sorbato de potássio em relação ao peso do néctar. $\mathrm{O}$ sorbato foi utilizado como conservante. A quantidade adicionada está dentro dos limites permitidos pela Legislação brasileira (Brasil, 1988b).

\section{Tratamento 4: Purê de pêssego + sacarose + ác. cítrico + sorbato de potássio + ác. Ascórbico}

Este tratamento seguiu o mesmo procedimento que $o$ anterior (Tratamento 3), porém, com adição de $0,03 \%$ de ácido ascórbico em relação ao peso do néctar. $\mathrm{O}$ ácido ascórbico foi utilizado como antioxidante. A quantidade adicionada está dentro dos limites permitidos pela Legislação brasileira (Brasil, 1988b).

\subsubsection{Néctar light}

O néctar light consistiu na mistura, em peso, de 50 partes de purê e 50 partes de xarope de edulcorantes (sorbitol + aspartame) com ${ }^{\circ}$ Brix suficiente para se obter o néctar com Brix de equilíbrio ao redor de $12^{\circ}$.

Os tratamentos utilizados para a obtenção do néctar light estão indicados na Figura 3.

O néctar light dos dois cultivares de pêssego apresentou os seguintes valores centesimais: $33,38 \mathrm{Kcal}, 12,06 \mathrm{~g}$ de aspartame + sorbitol e 3,43g de açúcar da fruta.

A) Tratamentos para a obtenção do néctar light 


\section{CULTIVAR}

\begin{tabular}{cccc}
\multicolumn{4}{c}{ NECTAR LIGHT } \\
& \multicolumn{4}{c}{} & & \\
\hline 1 & 2 & 3 & 4 \\
\hline purê de & purê de & purê de & purê de \\
pêssego & pêssego & pêssego & pêssego \\
+ & + & + & + \\
xarope de & xarope de & xarope de & xarope de \\
edulcorantes & edulcorantes & edulcorantes & edulcorantes \\
+ & + & + & + \\
ácido cítrico & ácido cítrico & ácido cítrico & ácido cítrico \\
& + & + & + \\
& refrigeração & sorbato de & sorbato de \\
& $\left(5-6^{\circ} \mathrm{C}\right)$ & potássio & potássio \\
& & & + \\
& & & ácido ascórbico \\
\hline
\end{tabular}

Figura 3 - Esquema dos tratamentos aplicados ao purê de pêssego para obtenção de néctar light.

\section{Tratamento 1: Purê de pêssego + xarope de edulcorantes + ácido cítrico}

Após o preparo e despolpamento das frutas, um lote de $2900 \mathrm{~g}$ de purê de pêssego a $10,72^{\circ}$ Brix (cultivar Dourado-2) e outro lote de mesmo peso a 9,47 ${ }^{\circ}$ Brix (cultivar Aurora-1) foram misturados, respectivamente, com $2900 \mathrm{~g}$ de xarope de edulcorantes (97\% de sorbitol e 3\% de aspartame) a $13,30^{\circ}$ Brix (cultivar Dourado-2) e $2900 \mathrm{~g}$ do xarope a $14,53^{\circ}$ Brix (cultivar Aurora-1), a fim de se obter o néctar, para cada cultivar, a $12^{\circ} \mathrm{Brix}$ (selecionado em testes preliminares) sem sofrer alteração devido ao aquecimento. A seguir, com adição de ácido cítrico em quantidade suficiente 
para reduzir o $\mathrm{pH}$ do néctar inicialmente de 4,2 (cultivar Aurora-1) e de 3,75 (cultivar Dourado-2) para o valor próximo de 3,5. Então o néctar foi homogeneizados, acidificado, submetido os tratamentos e pasteurizado por aquecimento em imersão em água sob vapor, em recipientes de aço inox, até atingir a temperatura de $90^{\circ} \mathrm{C}$, estando assim, pronto para $\mathrm{o}$ acondicionamento em latas, recravação, resfriamento a temperatura ambiente e armazenamento refrigerado e ambiente.

As amostras deste tratamento foram armazenadas à temperatura ambiente.

\section{Tratamento 2: Purê de pêssego + xarope de edulcorante + ácido cítrico + refrigeracão}

Este tratamento seguiu o mesmo procedimento que o Tratamento 1, porém, as amostras foram armazenadas à temperatura de refrigeração (5 $\left.6^{\circ} \mathrm{C}\right)$.

\section{Tratamento 3: Purê de pêssego + xarope de edulcorante + ácido cítrico + sorbato de potássio}

Este tratamento seguiu o mesmo procedimento que o Tratamento 1, porém, com adição de $0,1 \%$ de sorbato de potássio em relação ao peso do néctar. $\mathrm{O}$ sorbato foi utilizado como conservante. A quantidade adicionada está dentro dos limites permitidos pela Legislação brasileira (Brasil, 1988b).

\section{Tratamento 4: Purê de pêssego + xarope de edulcorante + ác. cítrico + sorbato de potássio + ác. Ascórbico}


Este tratamento seguiu o mesmo procedimento que o anterior (Tratamento 3), porém, com adição de $0,03 \%$ de ácido ascórbico em relação ao peso do néctar. $\mathrm{O}$ ácido ascórbico foi utilizado como antioxidante. A quantidade adicionada está dentro dos limites permitidos pela Legislação brasileira (Brasil, 1988b).

\subsubsection{Acondicionamento}

O acondicionamento dos néctares dos dois cultivares de pêssego foi realizado à quente $\left(90^{\circ} \mathrm{C}\right)$ em latas metálicas de folha-de-flandres, com capacidade de $410 \mathrm{~g}(74,6$ × 95,2 $\mathrm{mm})$ revestida internamente com verniz epoxi, apropriado para produtos ácidos. Cada lata foi completamente preenchida com o néctar (aproximadamente $360 \mathrm{~g}$ ) sem espaço livre.

\subsubsection{Recravação}

Após o preenchimento do volume das latas com o néctar, estas foram recravadas com auxílio de recravadeira mecânica, e a seguir, foram invertidas por 3 minutos, para a pasteurização das tampas.

\subsubsection{Resfriamento}

O resfriamento foi realizado a seguir através da imersão das latas em tanque com circulação de água fria, até atingir à temperatura ambiente.

\subsubsection{Armazenamento}

Após resfriadas as latas foram armazenadas em prateleiras à temperatura ambiente, com exceção do tratamento 2 ( respectivo aos dois produtos e os dois cultivares), cujas amostras foram mantidas sob refrigeração $\left(5-6^{\circ} \mathrm{C}\right)$. 


\subsection{Avaliação do produto processado}

Para determinar qual o cultivar que melhor se adaptou ao processamento, assim como avaliar aa características dos néctares e a eficiência dos tratamentos aplicados, foram realizadas as seguintes análises :

\subsubsection{Análise química:}

As análises de acidez total titulável, sólidos solúveis totais, $\mathrm{pH}$ e vitamina C. Foram realizadas por um período de 6 meses, aos $0,30,60,90$, 120 e 180 dias de armazenamento. Os procedimentos utilizados para estas análises foram os mesmos já mencionados e descritos para as análises químicas da matéria-prima (ítem 4.2.2.), diferenciando apenas por ter como amostras o néctar processado.

Todas as determinações químicas realizadas no produto final foram efetuadas com duas repetições, em amostras tomadas aleatoriamente dos lotes dos produtos processados dos dois cultivares em estudo.

\subsubsection{Análise física:}

Foram realizadas por um período de 6 meses, aos $0,30,60,90,120$ e 180 dias de armazenamento.

a) Peso bruto: Determinado como o peso total do recipiente com todo o produto contido (néctar). O peso bruto, assim como os demais pesos, foi determinado, utilizando-se de balança semi-analítica com precisão de $0,01 \mathrm{~g}$.

b) Peso líquido: Determinado como o peso do conteúdo da lata, isto é, o peso bruto descontado o peso da lata vazia, limpa e seca. 
c) Vácuo: Determinado como a diferença entre a pressão externa (do ambiente) e a pressão interna do recipiente. A exaustão formou o vácuo, que foi medido em polegadas de mercúrio.

Para medir o vácuo, utilizou-se o vacuômetro manual "Marshalltown", depois de: i) umidecer ligeiramente a tampa do recipiente, para propiciar maior contato; ii) colocar firmemente o vacuômetro próximo da borda da tampa e comprimir, perfurando-a (nunca colocar próximo ao centro da tampa da lata; e, iii) ler em polegadas de (pol.Hg).

\subsubsection{Análise sensorial}

A característica sensorial do néctar e néctar light de pêssego foram avaliadas quanto aos parâmetros de consistência, sabor e cor por uma equipe de oito julgadores, previamente selecionada e treinada para a avaliação desse tipo de produto (Dawson, 1964; Girardot et al., 1952 e Martin, 1973). Esta avaliação foi feita utilizando-se uma escala numérica estruturada de 9 pontos por um período de 3 meses, aos 30,60 e 90 dias de armazenamento. Os modelos de fichas que foram utilizadas nestas avaliações estão apresentadas nas Figuras 4,5 e 6.

Para a avaliação da cor dos néctares, as amostras, foram devidamente codificadas, e colocadas em placas de Petri, as quais foram dispostas

aleatoriamente em superfície branca em local com iluminação de luz fluorescente.

Para a avaliação da consistência e sabor dos néctares, o produto foi servido em copos de plástico branco $(50 \mathrm{~mL})$, codificados com números aleatórios de três dígitos e colocados em cabines individuais iluminadas com lâmpada comercial vermelha, a qual tem a finalidade de mascarar a cor dos produtos. 


\section{AVALIAÇÃO SENSORIAL}

Produto:

Nome do provador:

Data

Por favor, prove as amostras e indique a intensidade da Consistência, de acordo com a escala abaixo:

\begin{tabular}{|c|c|c|c|c|c|c|}
\hline & Péssima & Ruim & Regular & Boa & Ótima & Observações \\
\hline Amostras & 1 & 23 & $\begin{array}{lll}4 & 5 & \end{array}$ & 78 & 9 & \\
\hline & & & & & & \\
\hline & & & & & & \\
\hline & & & & & & \\
\hline & & & & & & \\
\hline
\end{tabular}

Figura 4: Modelo de ficha utilizado na avaliação sensorial das amostras do néctar quanto à consistência.

Por favor, prove as amostras e indique a intensidade do $\underline{\text { Sabor, }}$ de acordo com a escala abaixo:

\begin{tabular}{|c|c|c|c|c|c|c|}
\hline & Péssima & Ruim & Regular & Boa & Ótima & Observações \\
\hline Amostras & 1 & 23 & 456 & 78 & 9 & \\
\hline & & & & & & \\
\hline & & & & & & \\
\hline & & & & & & \\
\hline & & & & & & \\
\hline
\end{tabular}

Figura 5: Modelo de ficha utilizado na avaliação sensorial das amostras do néctar quanto ao sabor. 


\section{AVALIAÇÃO SENSORIAL}

Produto:

Nome do provador:

Data.

Por favor, analise as amostras e indique a intensidade da $\underline{\text { Cor }}$, de acordo com a escala abaixo:

\begin{tabular}{|c|c|c|c|c|c|c|c|}
\hline \multirow[b]{2}{*}{ Amostras } & Péssima & Ruim & Regula & \multicolumn{2}{|c|}{ Boa } & \multirow{2}{*}{$\begin{array}{c}\text { Ótima } \\
9\end{array}$} & \multirow[t]{2}{*}{ Observações } \\
\hline & 1 & 23 & 456 & & 8 & & \\
\hline & & & & & & & \\
\hline & & & & & & & \\
\hline & & & & & & & \\
\hline & & & & & & & \\
\hline
\end{tabular}

Figura 6: Modelo de ficha utilizado na avaliação sensorial das mostras de néctar quanto à cor.

A análise sensorial foi efetuada, de preferência, duas horas após as refeições, períodos estes mais adequados para a realização do teste. As avaliações foram feitas com duas repetições, de forma que cada provador pudesse avaliar a mesma amostra duas vezes, em sessões diferentes.

\subsubsection{Análise Estatística}

a) Matéria-prima

Os resultados da matéria-prima são apresentados através de médias com seus respectivos erros-padrão, correspondendo às duas repetições.

b) Néctar e néctar light

Os dados dos néctares foram analisados estatisticamente através do delineamento em blocos casualizados, com quatro tratamentos e duas 
repetições para cada cultivar testado, com a utilização do teste de Tukey (5\%) ( Gomes, 1982; Banzatto \& Kronka, 1995).

Todas as médias tiveram o mesmo número de repetições; os tratamentos foram designados às parcelas de forma casual, sendo essa casualização feita dentro de cada bloco (época de avaliação) (Banzatto \& Kronka, 1995).

As médias obtidas na avaliação sensorial foram analisadas pelo delineamento de blocos casualizados com quatro tratamentos e oito repetições para cada produto testado, com utilização do teste de Tukey (5\%). Cada provador foi designado como sendo um bloco. 


\section{RESULTADOS E DISCUSSÃO}

\section{1. - Caracterização da matéria-prima}

\subsection{1. - Análise física}

Os resultados da avaliação objetiva dos atributos físicos (textura e rendimento) estão apresentados na Tabela 1.

Tabela 1 - Características físicas dos cultivares de pêssego in natura (matéria-prima).

Médias das Análises (2 repetições)

Características Cultivares

Físicas

Aurora-1

Dourado-2

Textura $(\mathrm{lbf} / \mathrm{g})$

$4,04 \pm 0,53$

$1,36 \pm 0,32$

Rendimento (\%)

$61,17 \pm 0,2$

$55,77 \pm 0,3$

Segundo Chitarra \& Chitarra (1990), a textura é definida como "o conjunto de propriedades do alimento, composto por características físicas perceptiveis pelo tato e que se relacionam com a deformação, desintegração e fluxo do alimento, sob a aplicação de uma força". As sensações que caracterizam a textura das frutas e hortaliças são múltiplas, na sua maioria induzidas por características mecânicas, embora também possam ser induzidas por características geométricas ou químicas. As principais sensações são de dureza, maciez, fibrosidade, suculência, granulosidade, 
qualidade farinácea, resistência e elasticidade. Em frutas, a textura é caracterizada pela maciez.

De acordo com Bourne (1982), a firmeza é um importante fator na qualidade das frutas. Muitas frutas são colhidas a um certo nível de firmeza, que é utilizado para estabilizar um grau de qualidade e preço no mercado.

Comparando os cultivares estudados (Tabela 1), verifica-se que 0 cultivar Aurora-1 apresentou uma textura bem mais firme que o cultivar Dourado-2, confirmando as características descritas na literatura (ítem 3.2) para estes cultivares.

Segundo Chitarra \& Chitarra (1990) frutas e hortaliças destinadas ao processamento, devem ser firmes o suficiente para suportarem os tratamentos térmicos, estando a firmeza diretamente correlacionada ao conteúdo e tipo de pectina presentes. As substâncias pécticas são os principais componentes químicos dos tecidos, responsáveis pelas mudanças de textura das frutas e hortaliças.

A medida que as frutas amadurecem ocorre a degradação das substâncias pécticas, o que pode ser facilmente observado pelo amolecimento da polpa das mesmas ( Leme Jr., 1968).

O rendimento é um importante parâmetro de qualidade no processamento de produtos (purês, doces em massa, néctares, sucos) já que reflete quantitativamente, uma característica desejável para a indústria. As porcentagens de rendimento dos dois cultivares estudadas mostraram que para cada $1000 \mathrm{~g}$ de pêssego in natura $611,7 \mathrm{~g}$ da Aurora-1 e 557,7g da Dourado-2 foram utilizadas para processamento, o que indica um alto rendimento e ótima qualidade da matéria-prima, com ausência de frutas amassadas, machucadas ou deterioradas por microrganismos. 


\subsection{2 - Análise química}

$\mathrm{Na}$ Tabela 2, são apresentados os resultados das determinações de $\mathrm{pH}$, acidez total titulável, sólidos solúveis totais e ácido ascórbico da matériaprima.

Tabela 2 - Características químicas dos cultivares de pêssego in natura (matéria-prima).

\section{Médias das Análises}

Características Cultivares

Químicas Aurora-1 Dourado-2

$\mathrm{pH}$

$4,20 \pm 0,010$

$3,75 \pm 0,013$

Acidez total titulável $(\mathrm{g} / 100 \mathrm{~g})$

$0,124 \pm 0,100$

$0,165 \pm 0,080$

Sólidos solúveis totais $\left({ }^{\circ} \mathrm{Brix}\right)$

$10,72 \pm 0,500$

$9,47 \pm 0,500$

Ácido ascórbico (mg/100g)

$51,85 \pm 1,500$

$54,52 \pm 1,800$

Os valores de $\mathrm{pH}$ obtidos para o cultivar Aurora-1 foram inferiores aos descritos por Ojima et al. (1987), o mesmo acontecendo para o cultivar Dourado-2 em relação aos resultados apresentados por Ojima et al. (1985).

A acidez dos cultivares em estudo foi analisada em termos de $\mathrm{pH}$ e acidez total titulável (g ácido cítrico/100g fruta). De acordo com Chitarra \& Chitarra (1990), os ácidos orgânicos encontram-se dissolvidos nos vacúolos das células, tanto na forma livre, como combinada com sais, ésteres e glicosídeos. Em frutas, não só contribuem para a acidez como também para o aroma característico, porque alguns componentes são voláteis.

Acidez e pH são fatores de grande importância na aceitação de um produto, pois se este for extremamente ácido há prejuízo no consumo 
principalmente no mercado nacional, cuja preferência é para produtos pouco ácidos (Albregts \& Howard, 1978).

Comparando-se os valores de $\mathrm{pH}$ e acidez total titulável (Tabela 2), pode-se dizer que o cultivar Aurora-1 é menos ácida que a Dourado-2, já que aquela apresentou menor valor médio de acidez total, bem como maior valor de $\mathrm{pH}$.

Os sólidos solúveis totais (Tabela 2) indicam a percentagem em peso de sólidos que se encontram dissolvidos no produto. São designados em ${ }^{\circ}$ Brix, no caso de frutas, e têm a tendência de aumentar com a maturação, através de processos de biossíntese ou pela degradação de polissacarídeos. Este parâmetro químico representa uma das melhores formas de avaliação do grau de doçura do produto, já que o teor de açúcares normalmente constitui 65 a $85 \%$ do teor de sólidos solúveis totais (Chitarra \& Chitarra, 1990).

A Tabela 2 mostra que o cultivar Aurora-1 apresentou maior teor de sólidos solúveis $\left(10,72^{\circ} \mathrm{Brix}\right)$ do que o cultivar Dourado-2 $\left(9,47^{\circ} \mathrm{Brix}\right)$.

Iranzo \& Torán (1977) estudando sucos de frutas cítricas, observaram que o cultivar e o índice de maturação influem nos valores das relações entre os sólidos solúveis e as porcentagens dos açúcares totais e acidez.

Comparando os valores do teor de ácido ascórbico (Tabela 2), verifica-se que a Dourado-2 é mais rica nesta vitamina $(54,52 \mathrm{mg} / 100 \mathrm{~g})$. Estes resultados estão de acordo com os valores obtidos em frutas frescas citados por (Eskin, 1991) e (Chitarra \& Chitarra, 1990), porém representam valores maiores em relação ao apresentado para pêssego fresco $(26,8 \mathrm{mg} / 100 \mathrm{~g})$ relatado por Franco (1992). 


\section{2 - Caracterização do néctar}

\subsection{1 - Análise física}

Os valores médios de vácuo das latas dos néctares, para ambos cultivares (Tabela 3) não apresentaram diferenças estatísticas significativas em relação aos tratamentos, porém para a Dourado-2 as diferenças foram significativas em relação ao tempo de armazenamento.

A faixa de vácuo normal numa lata de fruta em calda está entre 8 e 15 pol.Hg. Se o vácuo for muito baixo há o risco de rápida oxidação do produto devido ao excesso de oxigênio presente. Portanto, os valores de vácuo encontrados estão dentro da faixa considerada normal. De acordo com Martin et al. (1965/66), o vácuo é dependente das operações de exaustão e da temperatura do produto na operação de fechamento das latas. Assim sendo, pode-se dizer que a operação de recravação das latas foi feita de maneira adequada, evitando-se o efeito prejudicial das reações oxidativas, que resultam na rápida degradação do ácido ascórbico, escurecimento e alterações organolépticas do néctar.

O oxigênio pode estar na fase gasosa (espaço-livre), dissolvido na fase aquosa ou adsorvido na fase sólida ou semi-sólida. A temperatura de fechamento do recipiente tem grande importância no processo de formação de vácuo (Evangelista, 1992).

O vácuo, mesmo sendo dependente do processamento, mostrou variações que podem ser atribuídas como decorrentes de demora na operação de recravação, ou ainda ao espaço-livre (este último sendo também dependente do volume do néctar adicionado). Os valores de vácuo, encontrados após o período de 180 dias, foram considerados ótimo para a 
Tabela 3 - Valores médios do vácuo (pol. Hg) das latas dos néctares, em função do tempo de armazenamento

\begin{tabular}{|c|c|c|c|c|c|c|c|c|c|c|}
\hline \multicolumn{11}{|c|}{ Cultivares } \\
\hline & \multicolumn{4}{|c|}{ Aurora-1 } & \multicolumn{6}{|c|}{ Dourado-2 } \\
\hline $\begin{array}{l}\text { Tempo de } \\
\text { Armazenamento } \\
\text { (dias) }\end{array}$ & $\mathrm{T} 1$ & $\mathrm{~T} 2$ & $\mathrm{~T} 3$ & $\mathrm{~T} 4$ & Médias & $\mathrm{Tl}$ & $\mathrm{T} 2$ & $\mathrm{~T} 3$ & $\mathrm{~T} 4$ & Médias \\
\hline 0 & 10,00 & 12,00 & 12,00 & 10,75 & $11,19^{A}$ & 10,25 & $10,7 \overline{5}$ & 10,25 & 10,50 & $10,44^{\mathrm{C}}$ \\
\hline 30 & 10,25 & 11.25 & 10,75 & 13,00 & $11,31^{A}$ & 10,25 & 10,50 & 11,50 & 10,75 & $10,75^{\mathrm{ABC}}$ \\
\hline 60 & 11,75 & 10,25 & 11,25 & 10,50 & $10,94^{A}$ & 10,75 & 10,50 & 10,50 & 10,25 & $10,50^{\mathrm{BC}}$ \\
\hline 90 & 13,00 & 11,25 & 11,50 & 12,25 & $12,00^{\mathrm{A}}$ & 13,00 & 12,25 & 11,25 & 10,50 & $11,75^{\mathrm{ADC}}$ \\
\hline 120 & 12,25 & 12,75 & 12,50 & 11,25 & $12,19^{A}$ & 11,50 & 12,25 & 12,25 & 11,50 & $11,87^{\mathrm{AB}}$ \\
\hline 150 & 12,25 & 12,50 & 12,50 & 10,75 & $12,00^{A}$ & 11,25 & 10,75 & 12,50 & 11,75 & $11,56^{\mathrm{ABC}}$ \\
\hline 180 & 12,25 & 11,25 & 12,25 & 10,50 & $11,56^{\mathrm{A}}$ & 11,75 & 12,25 & 12,75 & 11,25 & $12,00^{\mathrm{A}}$ \\
\hline Médias & $11,68^{A}$ & $11,61^{A}$ & $11,82^{A}$ & $11,29^{A}$ & & $11.25^{A}$ & $11,32^{A}$ & $11, \overline{57^{\mathrm{A}}}$ & $10,93^{A}$ & \\
\hline $\mathrm{F}$ (Trat) & \multirow{2}{*}{\multicolumn{4}{|c|}{$\begin{array}{l}0,42 \text { n.s. } \\
1,18 \text { n.s. }\end{array}$}} & \multirow{2}{*}{\multicolumn{6}{|c|}{$\begin{array}{l}0,66 \text { n.s. } \\
4.68 *\end{array}$}} \\
\hline F(Tempo) & & & & & & & & & & \\
\hline
\end{tabular}

$\mathrm{T} 1, \mathrm{~T} 2, \mathrm{~T} 3$ e $\mathrm{T} 4=$ tratamentos

* = significativo ao nível de $5 \%$

n.s. = não significativo

Médias com a mesma letra não diferem entre si ao nível de 5\% de significância

conservação do produto final (o valor mínimo foi de 10,50 pol. $\mathrm{Hg}$ para o cultivar Aurora-1 e de 11,25 pol. Hg para o cultivar Dourado-2).

Freqüentemente, o oxigênio dissolvido no produto e/ou presente no espaço-livre, já é suficiente para desencadear as reações de oxidação, não bastando apenas a barreira da embalagem ao oxigênio. Logo, a desaeração do produto e o emprego de técnicas que reduzam o espaço-livre ou que diminuam a concentração de oxigênio no espaço-livre irão contribuir decididamente para o aumento da vida útil desses produtos (Alves \& Garcia, 1993).

O parâmetro peso bruto é importante para a indústria para fins de armazenamento e transporte, principalmente. No entanto, nunca aparece nos rótulos de produtos, pois não é de interesse do consumidor final.

Os valores de pesos médios (bruto e líquido) das latas dos néctares das duas variedades (Tabelas 4 e 5) não apresentaram diferenças significativas 
Tabela 4 - Valores médios do peso bruto (g) das latas dos néctares, em função do tempo de armazenamento

\section{Cultivares}

Aurora-1

Dourado-2

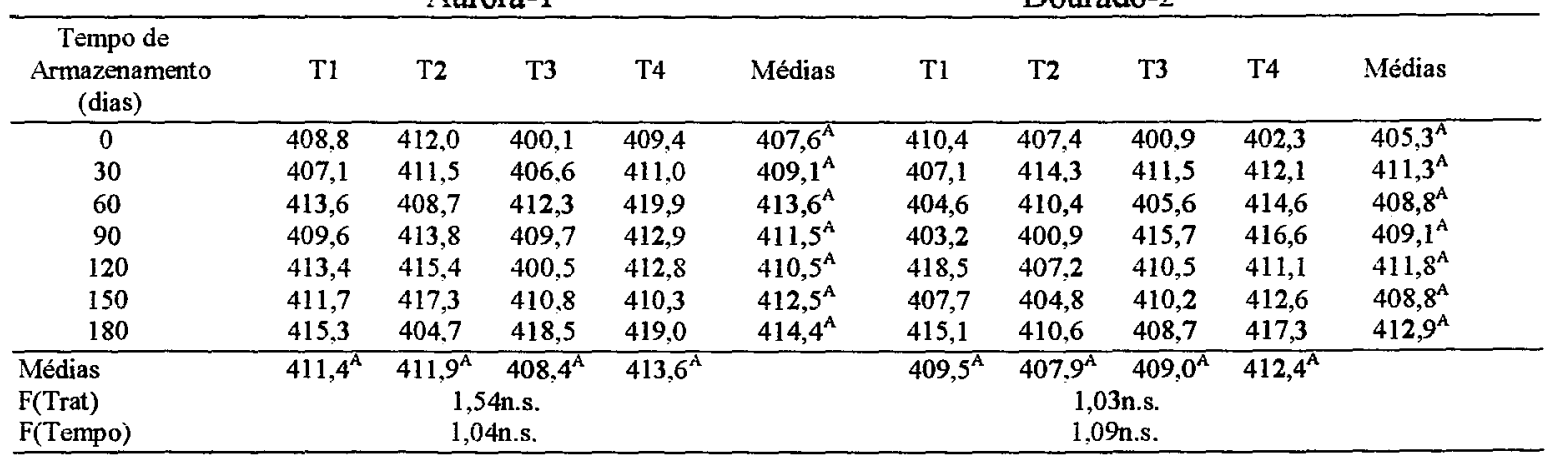

$\mathrm{T} 1, \mathrm{~T} 2, \mathrm{~T} 3$ e $\mathrm{T} 4=$ tratamentos

n.s. = não significativo

Médias com a mesma letra não diferem entre si ao nível de 5\% de significância

Tabela 5 - Valores médios do peso líquido $(\mathrm{g})$ das latas dos néctares, em função do tempo de armazenamento

\section{Cultivares}

\section{Aurora-1}

Dourado-2

\begin{tabular}{|c|c|c|c|c|c|c|c|c|c|c|}
\hline \multirow[b]{2}{*}{$\begin{array}{c}\text { Tempo de } \\
\text { Armazenamento } \\
\text { (dias) }\end{array}$} & \multicolumn{4}{|c|}{ 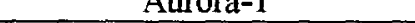 } & \multicolumn{6}{|c|}{$-4-\pi-1$} \\
\hline & $\mathrm{T} 1$ & $\mathrm{~T} 2$ & $\mathrm{~T} 3$ & T4 & Médias & $\mathrm{T} 1$ & $\mathrm{~T} 2$ & $\mathrm{~T} 3$ & T4 & Médias \\
\hline 0 & 340,2 & 355.9 & 343,0 & 353,3 & $348,1^{C}$ & 354,3 & 351,3 & 342,8 & 346,3 & $348,7^{\AA}$ \\
\hline 30 & 357,8 & 362.2 & 357.3 & 361.7 & $359,8^{\mathrm{BC}}$ & 357,8 & 365.0 & 362,2 & 362,8 & $362,0^{A}$ \\
\hline 60 & 364,6 & 359.7 & 363,3 & 370,9 & $364,6^{A}$ & 355,6 & 361,4 & 356,6 & 365,6 & $359,8^{A}$ \\
\hline 90 & 355,9 & 364,1 & 360,0 & 363,2 & $360,8^{\mathrm{ADC}}$ & 353,5 & 348.2 & 366,0 & 366,9 & $358,7^{A}$ \\
\hline 120 & 355,4 & 357,0 & 367,1 & 364,1 & $360,9^{A B C}$ & 358,3 & 330,9 & 353,7 & 358,8 & $350,4^{A}$ \\
\hline 150 & 363,4 & 3712 & 368.4 & 352.5 & $3639^{\mathrm{AB}}$ & 3432 & 3574 & 361.5 & 337.5 & $349,9^{A}$ \\
\hline 180 & 345,8 & 351.1 & 348,9 & 361.2 & $351,8^{\mathrm{ABC}}$ & 341,8 & 355.8 & 347,7 & 354,6 & $350,0^{A}$ \\
\hline Médias & $354,7^{\mathrm{A}}$ & $360.2^{A}$ & $358,3^{A}$ & $361,0^{A}$ & & $352,1^{A}$ & $352.9^{A}$ & $355,8^{A}$ & $356,1^{A}$ & \\
\hline F(Trat) & \multicolumn{4}{|c|}{$\begin{array}{l}0,87 \text { n.s. } \\
4,44^{*}\end{array}$} & \multicolumn{6}{|c|}{$0,32 \mathrm{n} . \mathrm{s}}$. \\
\hline
\end{tabular}

$\mathrm{T} 1, \mathrm{~T} 2, \mathrm{~T} 3$ e T4 = tratamentos

* = significativo ao nível de $5 \%$

n.s. = não significativo

Médias com a mesma letra não diferem entre si ao nível de 5\% de significância 
em relação aos tratamentos bem como ao longo do período de armazenamento. Somente para a Aurora-1 foi observada diferença significativa para peso líquido em função do tempo de armazenamento (Tabela 5). Estas análises mostraram que o preenchimento das latas foi feito de maneira adequada, obtendo-se assim, produtos com pesos semelhantes, fato esse altamente desejável em qualquer tipo de indústria de alimentos, uma vez que o peso é um dos importantes fatores no controle de qualidade.

\subsection{2 - Análise química}

$\mathrm{Na}$ Tabela 6 encontram-se os valores médios de ácido ascórbico constatados nas amostras do néctar dos cultivares Aurora-1 e Dourado-2. Verifica-se que as perdas desta vitamina, ao longo do período de armazenamento dos néctares de ambos cultivares não foram significativos, o que demonstra uma boa estabilidade dos produtos. Entre tratamentos somente o T4 diferiu dos demais, como era de se esperar, pois foi o que recebeu a adição de ácido ascórbico $(30 \mathrm{mg} / 100 \mathrm{~g})$.

As menores perdas com base no valor final de vitamina $\mathrm{C}$ foram constatadas nos tratamentos 2 e 4 , fato que pode ser explicado pelo armazenamento refrigerado (T2) e pela adição de sorbato de potássio (T4) que têm mostrado ser eficiente na preservação dessa vitamina (Goldini et al., 1981).

Durante estudo da estabilidade do néctar de acerola, Oliva et al. (1996) verificaram que, após 180 dias de armazenamento, houve uma redução no teor de ácido ascórbico da ordem de $27 \%$, a temperatura ambiente, e de $7,78 \%$ sob refrigeração. Comparando esses resultados com os apresentados neste trabalho, observa-se que, nas amostras dos néctares de 
Tabela 6 - Valores médios dos teores de ácido ascórbico (mg/100g) dos néctares, em função do tempo de armazenamento

\section{Cultivares}

Aurora-1

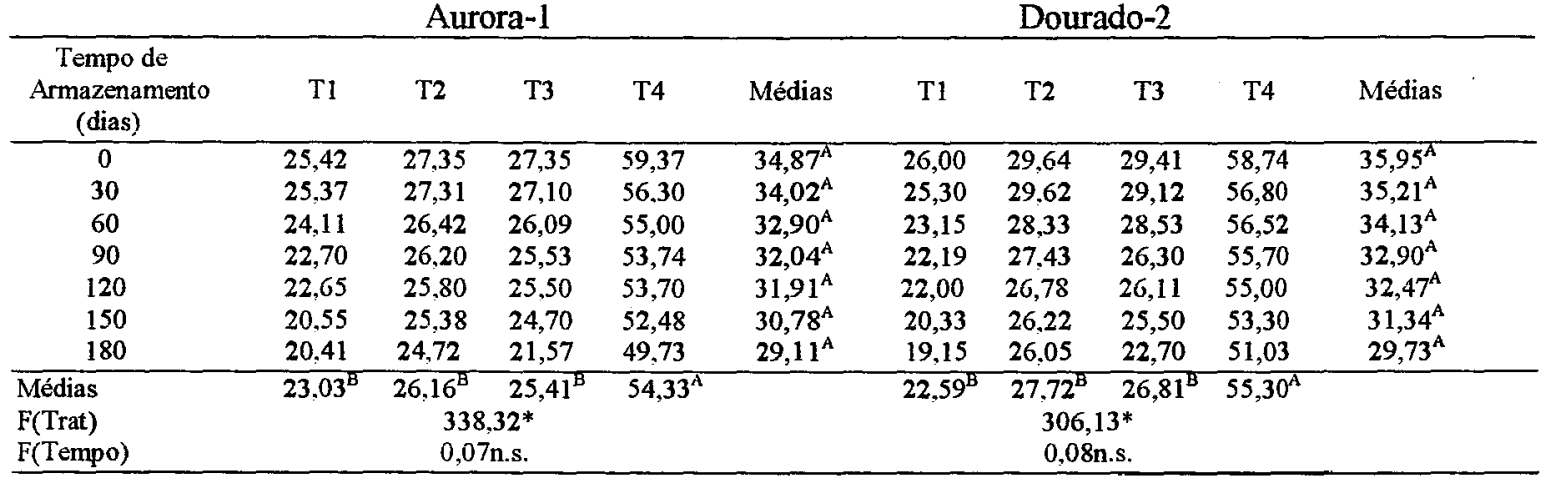

$\mathrm{T} 1, \mathrm{~T} 2, \mathrm{~T} 3$ e $\mathrm{T} 4=$ tratamentos

$*$ = significativo ao nível de $5 \%$

n.s. = não significativo

Médias com a mesma letra não diferem entre si ao nível de 5\% de significância

pêssego a redução foi para T1de $19,71 \%$, T3 de $21,13 \%$ e T4 de $16,24 \%$ para o cultivar Aurora-1; para T1 de 26,35\%, T3 de 22,82\% e T4 de 13,12\% para o cultivar Dourado-2 à temperatura ambiente e sob refrigeração de $9,62 \%$ (T2) para o cultivar Aurora-1 e 12,11\% (T2) para o cultivar Dourado2.

Ao estudar o comportamento do néctar de mamão, De Martin et al. (1972), observaram redução de $26 \%$ no teor de ácido ascórbico após 180 dias de armazenamento à temperatura ambiente. Bleinroth et al. (1977) analisaram o teor de ácido ascórbico em néctar de abacaxi-laranja durante seis meses de armazenamento, também a temperatura ambiente, e as perdas finais encontradas para esta vitamina ficaram entre 40 e $50 \%$ do teor inicial, dependendo da formulação utilizada.

Mesmo após seis meses de armazenamento, os néctares que não receberam adição de ácido ascórbico (T1, T2 e T3), apresentaram razoáveis 
teores desta vitamina (de 19,03mg/100g para o cultivar Aurora-1 e de 20,76mg/100g para o cultivar Dourado-2). O tratamento que recebeu adição de ácido ascórbico (T4) permitiu que os néctares dos dois cultivares apresentassem após 180 dias de armazenamento à temperatura ambiente, um teor final bem mais elevado (de $54,33 \mathrm{mg} / 100 \mathrm{~g}$, sendo $30,07 \mathrm{mg} / 100 \mathrm{~g}$ a mais que o teor natural da fruta) que os demais tratamentos.

Pode-se observar, pelas Figuras 7 e 8 a diminuição do teor de ácido ascórbico dos néctares, em função do tempo de armazenamento. Em todos os tratamentos houve perda de vitamina $\mathrm{C}$, com menor intensidade para $\mathrm{o}$ T4, devido a adição de ácido ascórbico no processamento.

Comparando os dois cultivares (Figura 9) observa-se que o cultivar Dourado-2 apresentou ao longo do armazenamento teores mais elevados de ácido ascórbico.

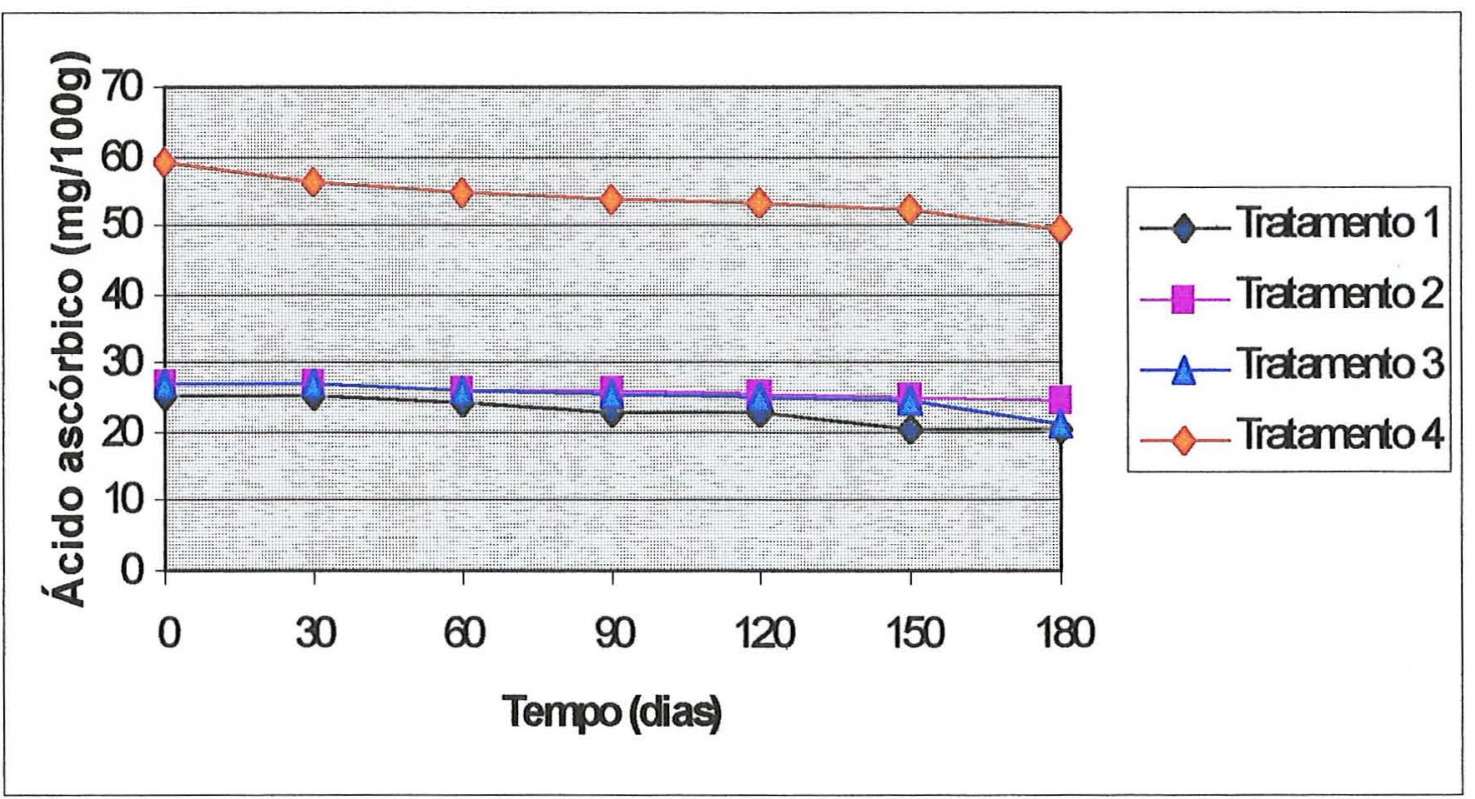

Figura 7 - Variação do teor de ácido ascórbico dos néctares da Aurora-1, em função do tempo de armazenamento 


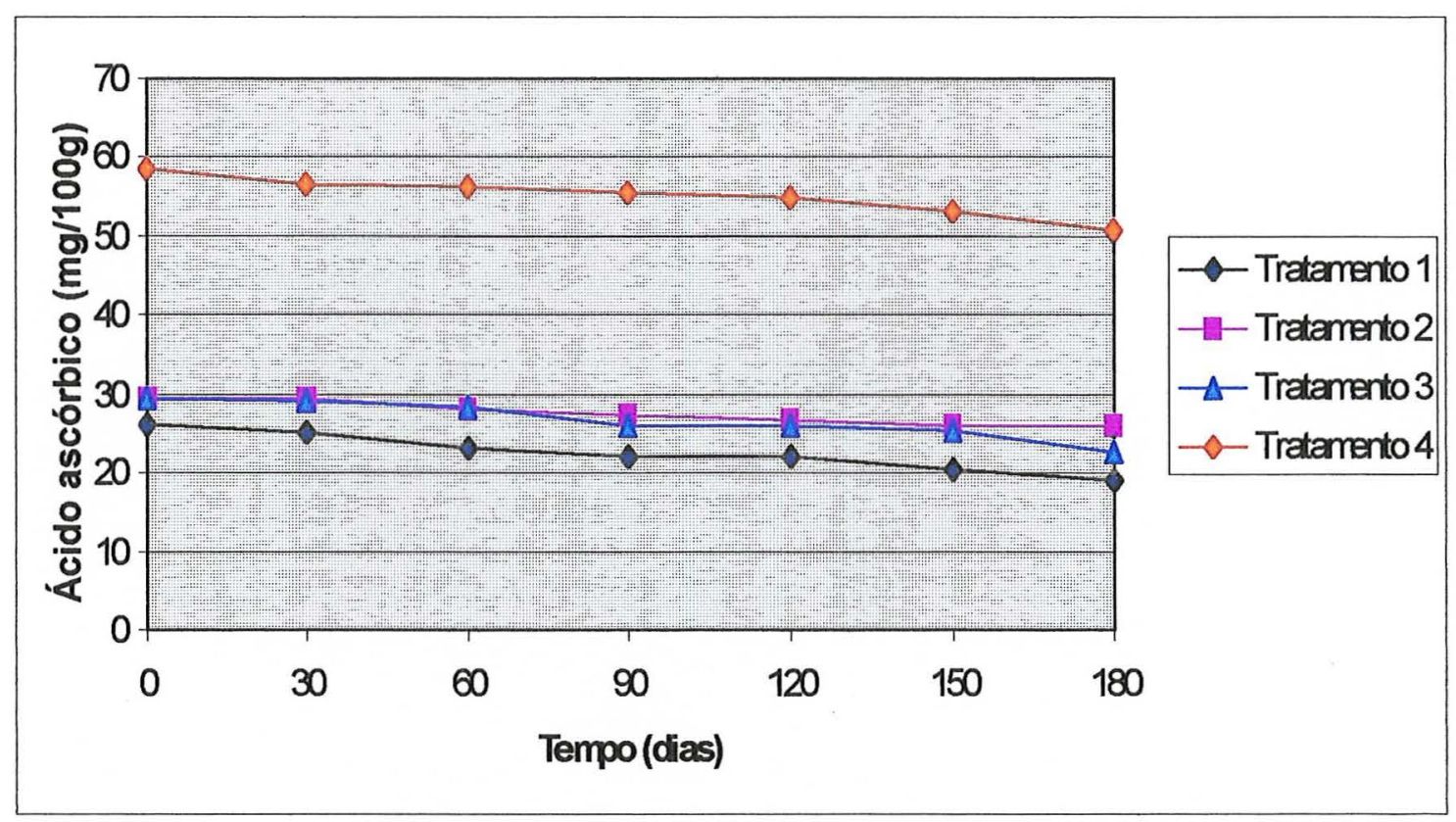

Figura 8 - Variação do teor de ácido ascórbico dos néctares da Dourado-2, em função do tempo de armazenamento

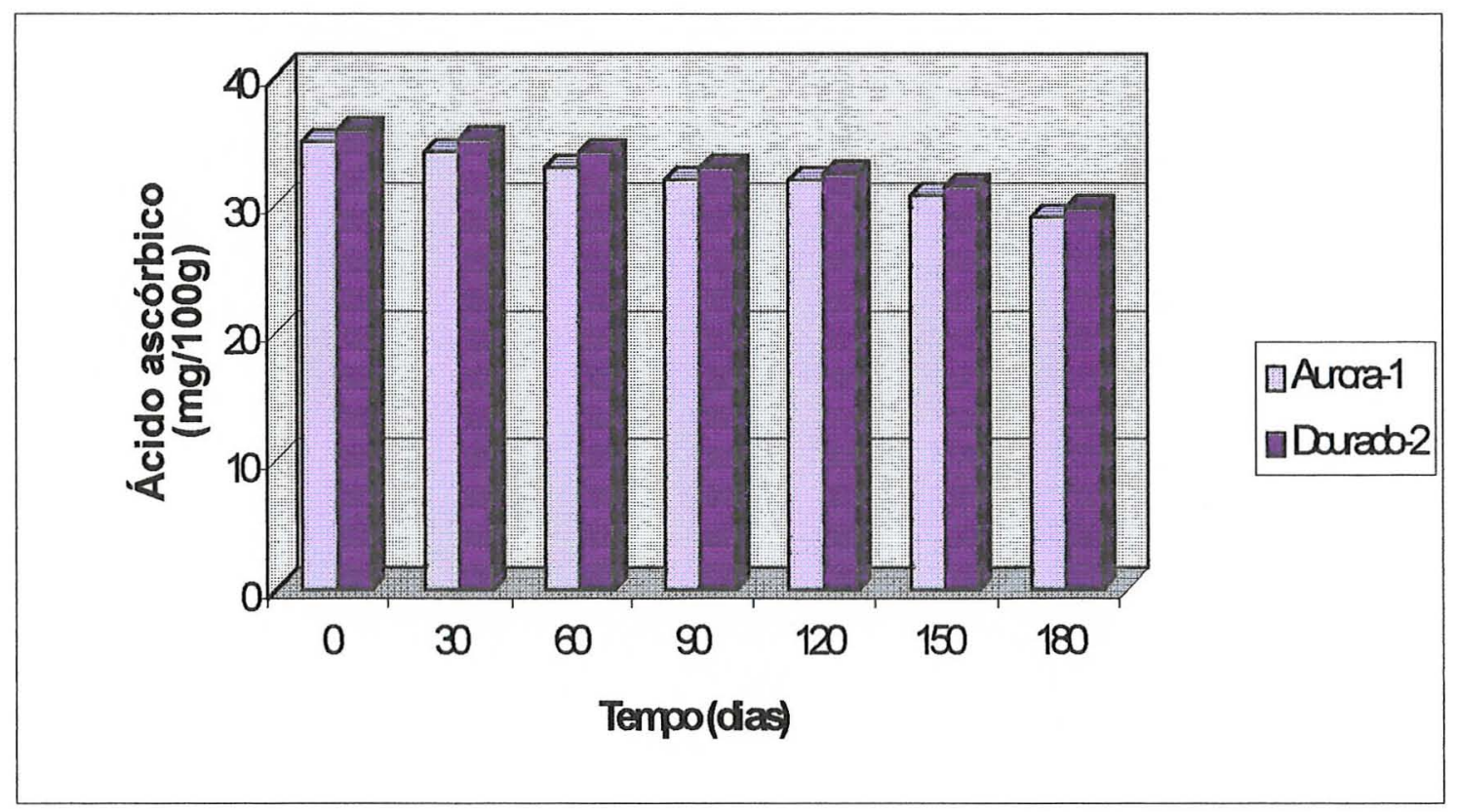

Figura 9 - Variação do teor de ácido ascórbico dos néctares, em função do tempo de armazenamento 
Pela Tabela 7 observa-se que quanto à acidez total titulável houve diferença estatística significativa entre os tratamentos mas não ao longo do período de armazenamento. Entretanto, ocorreu durante este período uma redução gradativa da acidez total titulável (Figuras 10 e 11).

Os níveis decrescentes da acidez total titulável foram acompanhados pela redução nos teores de ácido ascórbico, o que pode explicar o fato, pois este é um dos componentes da acidez total titulável. A Tabela 7 mostra também, que o tratamento 4 de ambos cultivares apresentou maior acidez total titulável, o que é explicado pela adição de ácido ascórbico ao referido tratamento.

As médias de acidez (Figura 12) dos néctares do cultivar Dourado-2 foram maiores do que as do cultivar Aurora-1, durante todo o armazenamento mostrando que a matéria-prima que apresenta maior acidez, (cultivar Dourado-2) origina um produto final com características mais ácidas.

Aradhita et al. (1995), estudando néctares de goiaba observaram um aumento progressivo nos valores de acidez total titulável ao longo do período em que se manteve armazenado. Já Gofur et al. (1994), utilizando várias formulações de néctar de manga não constataram diferenças significativas com relação à acidez total titulável, durante o armazenamento do produto.

Analisando a Tabela 8, observa-se que os valores médios de $\mathrm{pH}$ dos néctares, não diferiram estatisticamente entre tratamentos e nem em função do período de armazenamento. Esta estabilidade do pH (Figura 13) é conseqüência das características dos tratamentos aplicados e dos componentes equilibrados utilizados para o desenvolvimento do produto final, servindo de indicativo da qualidade microbiológica do produto. 
Tabela 7 - Valores médios de acidez total titulável (g ácido cítrico/100g) dos néctares, em função do tempo de armazenamento

\section{Cultivares}

Aurora-1

Dourado-2

\begin{tabular}{|c|c|c|c|c|c|c|c|c|c|c|}
\hline $\begin{array}{l}\text { Tempo de } \\
\text { Armazenamento } \\
\text { (dias) }\end{array}$ & $\mathrm{T} 1$ & $\mathrm{~T} 2$ & $\mathrm{~T} 3$ & $\mathrm{~T} 4$ & Médias & $\mathrm{T} 1$ & $\mathrm{~T} 2$ & T3 & $\mathrm{T} 4$ & Médias \\
\hline 0 & 0,154 & 0,160 & 0,228 & 0,247 & $0,197^{A}$ & 0,178 & 0,178 & 0,220 & 0,247 & $0,206^{A}$ \\
\hline 30 & 0,149 & 0,154 & 0,201 & 0,232 & $0,184^{A}$ & 0,170 & 0,175 & 0,216 & 0,235 & $0,199^{A}$ \\
\hline 60 & 0,145 & 0,150 & 0,195 & 0,217 & $0,177^{\mathrm{A}}$ & 0,165 & 0,170 & 0,210 & 0,223 & $0,192^{\mathrm{A}}$ \\
\hline 90 & 0,135 & 0,146 & 0,191 & 0,215 & $0,172^{A}$ & 0,161 & 0,167 & 0,198 & 0,217 & $0,186^{A}$ \\
\hline 120 & 0,131 & 0,142 & 0,188 & 0,211 & $0,168^{A}$ & 0,158 & 0,163 & 0,184 & 0,212 & $0,179^{A}$ \\
\hline $\begin{array}{l}120 \\
150\end{array}$ & 0,128 & $\begin{array}{l}0,142 \\
0,135\end{array}$ & 0,182 & 0,200 & $0,161^{\mathrm{A}}$ & 0,147 & 0,159 & 0,177 & 0,205 & $0,172^{A}$ \\
\hline 180 & 0,121 & 0,129 & 0,175 & 0,198 & $0,156^{\mathrm{A}}$ & 0,139 & 0,152 & 0,163 & 0,194 & $0,162^{\mathrm{A}}$ \\
\hline Médias & $0,137^{\mathrm{C}}$ & $0,145^{\mathrm{C}}$ & $0,194^{\mathrm{B}}$ & $0,217^{A}$ & & $0,160^{B}$ & $0,166^{\mathrm{B}}$ & $0,195^{A}$ & $0,219^{A}$ & \\
\hline F(Trat) & \multicolumn{4}{|c|}{$48,29 *$} & \multicolumn{6}{|c|}{$20,18^{*}$} \\
\hline F(Tempo) & \multicolumn{4}{|c|}{$0,53 \mathrm{n} . \mathrm{s}$. } & \multicolumn{6}{|c|}{1,20 n.s. } \\
\hline
\end{tabular}

$\mathrm{T} 1, \mathrm{~T} 2, \mathrm{~T} 3$ e $\mathrm{T} 4=$ tratamentos

* = significativo ao nível de 5\%

n.s. = não significativo

Médias com a mesma letra não diferem entre si ao nível de 5\% de significância

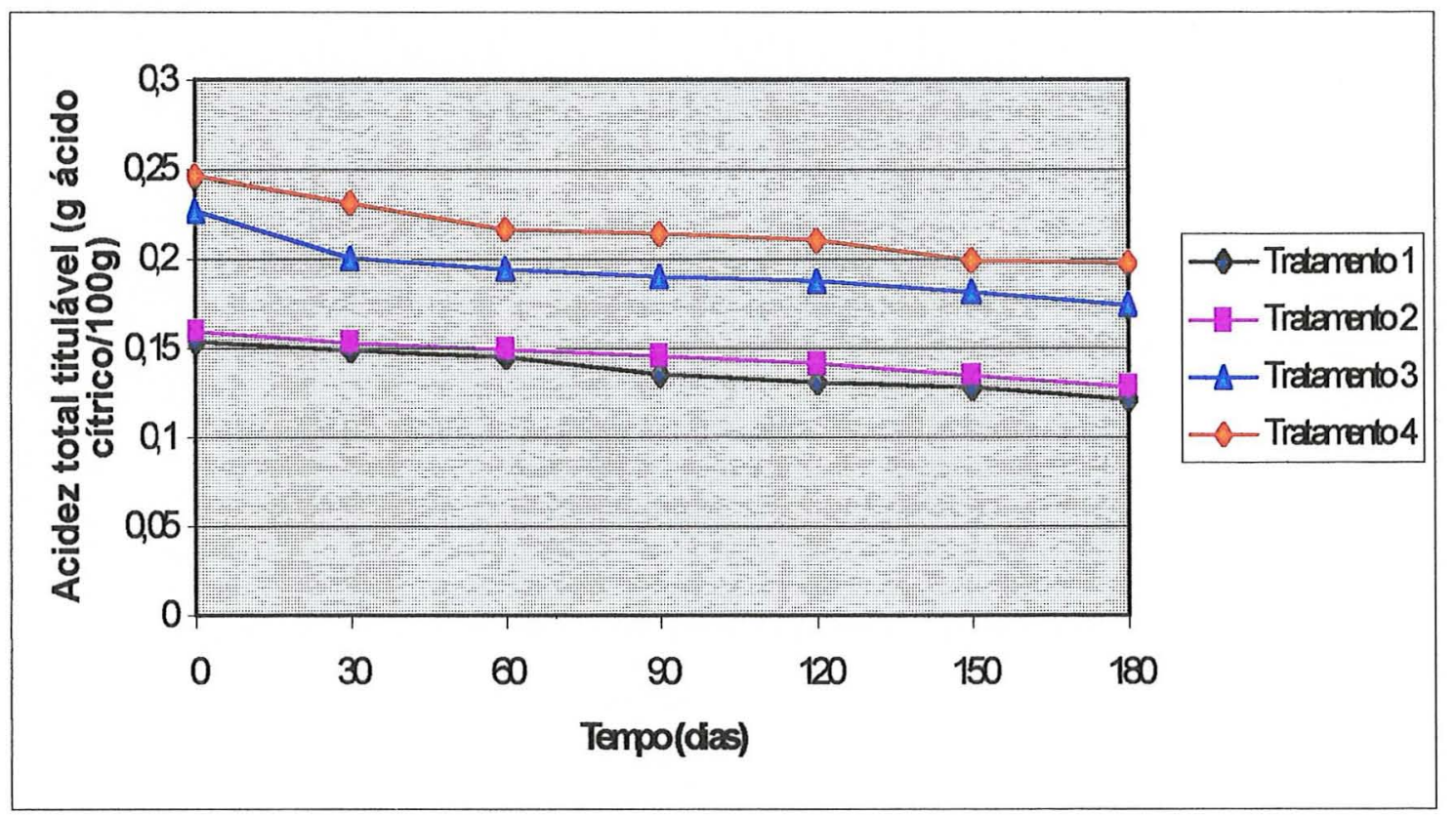

Figura 10 - Variação da acidez total titulável em néctares da Aurora1, em função do tempo de armazenamento 


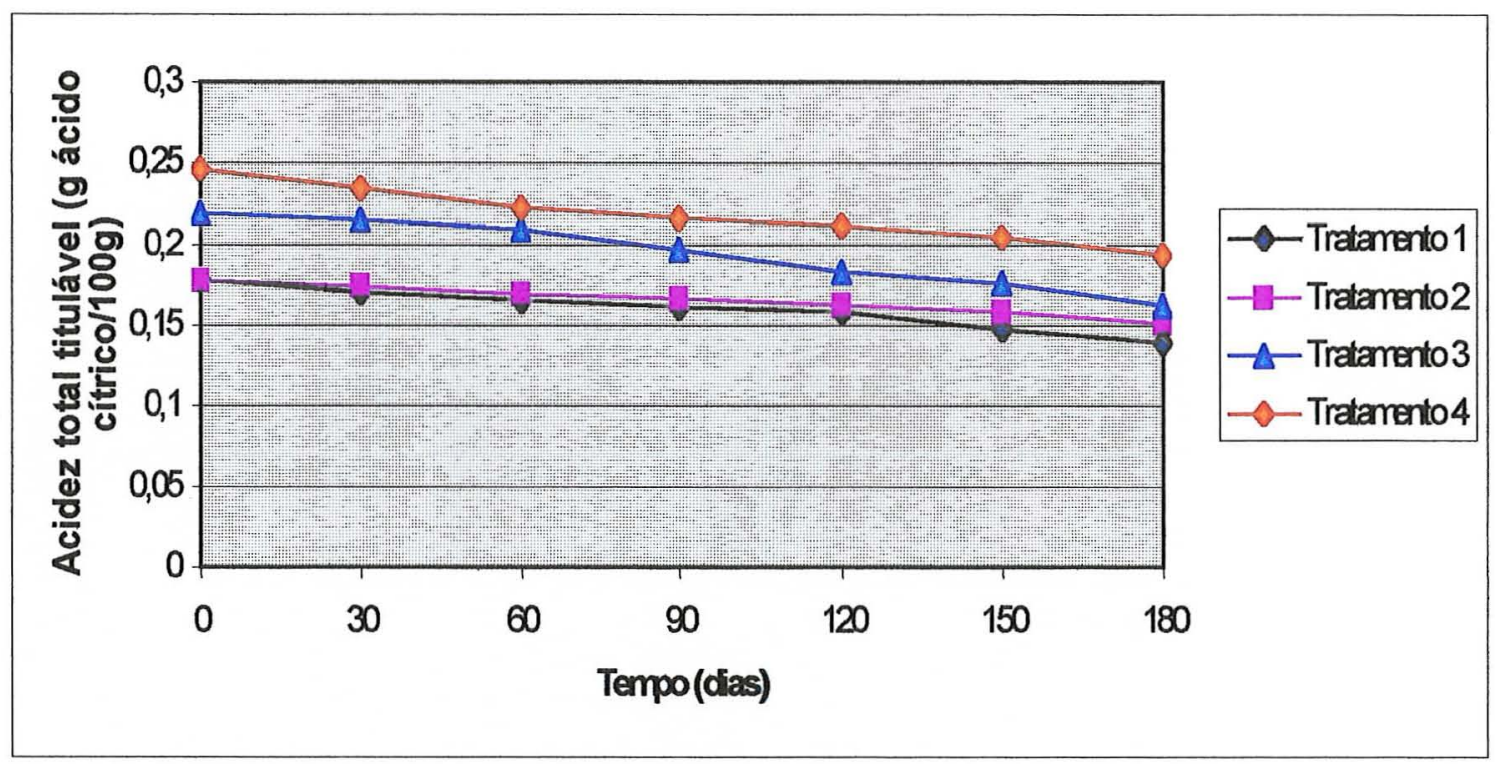

Figura 11 - Variação da acidez total titulável em néctares da Dourado-2, em função do tempo de armazenamento

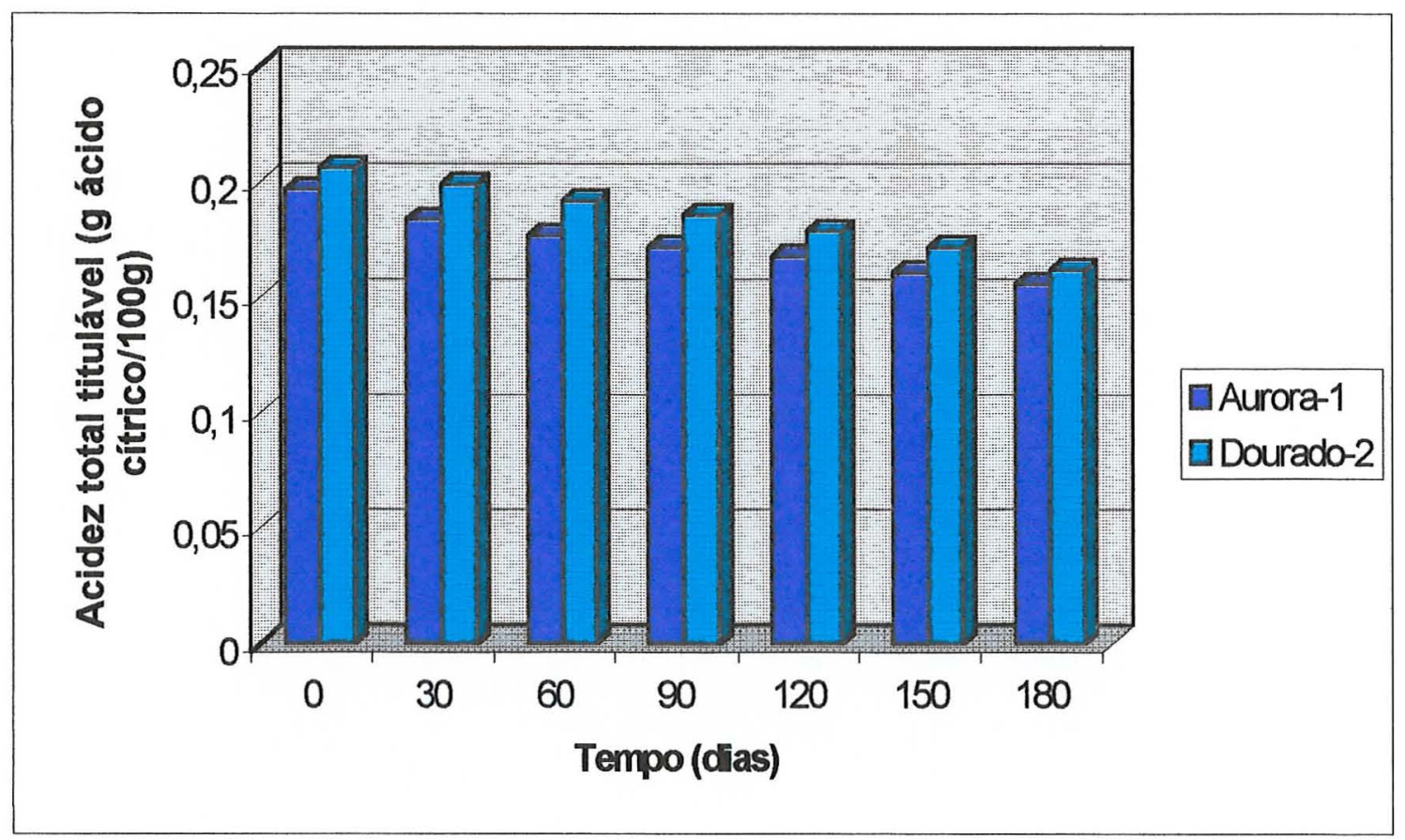

Figura 12 - Variação da acidez total titulável em néctares, em função do tempo de armazenamento 
Tabela 8 - Valores médios de $\mathrm{pH}$ dos néctares, em função do tempo de armazenamento

\section{Cultivares}

Aurora-1

Dourado-2

\begin{tabular}{|c|c|c|c|c|c|c|c|c|c|c|}
\hline \multirow[b]{2}{*}{$\begin{array}{l}\text { Tempo de } \\
\text { Armazenamento } \\
\text { (dias) }\end{array}$} & & \\
\hline & $\mathrm{T} 1$ & $\mathrm{~T} 2$ & T3 & $\mathrm{T} 4$ & Médias & $\mathrm{T} 1$ & $\mathrm{~T} 2$ & $\mathrm{~T} 3$ & $\mathrm{~T} 4$ & Médias \\
\hline 0 & 3,52 & 3,52 & 3,53 & 3,52 & $3,52^{A}$ & 3,53 & 3,52 & 3,53 & 3,52 & $3,53^{A}$ \\
\hline 30 & 3,52 & 3,54 & 3,53 & 3,52 & $3,53^{A}$ & 3,53 & 3,52 & 3,51 & 3,53 & $3,52^{\mathrm{A}}$ \\
\hline 60 & 3,51 & 3,53 & 3,53 & 3,52 & $3,52^{\mathrm{A}}$ & 3,52 & 3,52 & 3,52 & 3,52 & $3,52^{\mathrm{A}}$ \\
\hline 90 & 3,50 & 3,53 & 3,52 & 3,52 & $3,52^{\mathrm{A}}$ & 3,51 & 3,52 & 3,53 & 3,52 & $3,52^{\mathrm{A}}$ \\
\hline 120 & 3,52 & 3,52 & 3,52 & 3,52 & $3,52^{\mathrm{A}}$ & 3,52 & 3,52 & 3,53 & 3,52 & $3,52^{\mathrm{A}}$ \\
\hline 150 & 3,52 & 3,52 & 3,53 & 3,52 & $3,52^{\mathrm{A}}$ & 3,52 & 3,52 & 3,52 & 3,52 & $3,52^{\mathrm{A}}$ \\
\hline 180 & 3,52 & 3,51 & 3,52 & 3,53 & $3,52^{A}$ & 3,53 & 3,52 & 3,52 & 3,51 & $3,52^{\mathrm{A}}$ \\
\hline Médias & $3,52^{A}$ & $3,52^{A}$ & $3,53^{A}$ & $3,52^{A}$ & & $3,52^{A}$ & $3,52^{A}$ & $3,52^{A}$ & $3,52^{A}$ & \\
\hline $\mathrm{F}$ (Trat) & \multicolumn{4}{|c|}{$2,74 \mathrm{n} . \mathrm{s}}$. & \multicolumn{6}{|c|}{0,52 n.s. } \\
\hline F(Tempo) & \multicolumn{4}{|c|}{0,60 n.s. } & \multicolumn{6}{|c|}{0,38 n.s. } \\
\hline
\end{tabular}

$\mathrm{T} 1, \mathrm{~T} 2, \mathrm{~T} 3$ e $\mathrm{T} 4$ = tratamentos

$\mathrm{n} . \mathrm{s} .=$ não significativo

Médias com a mesma letra não diferem entre si ao nível de 5\% de significância

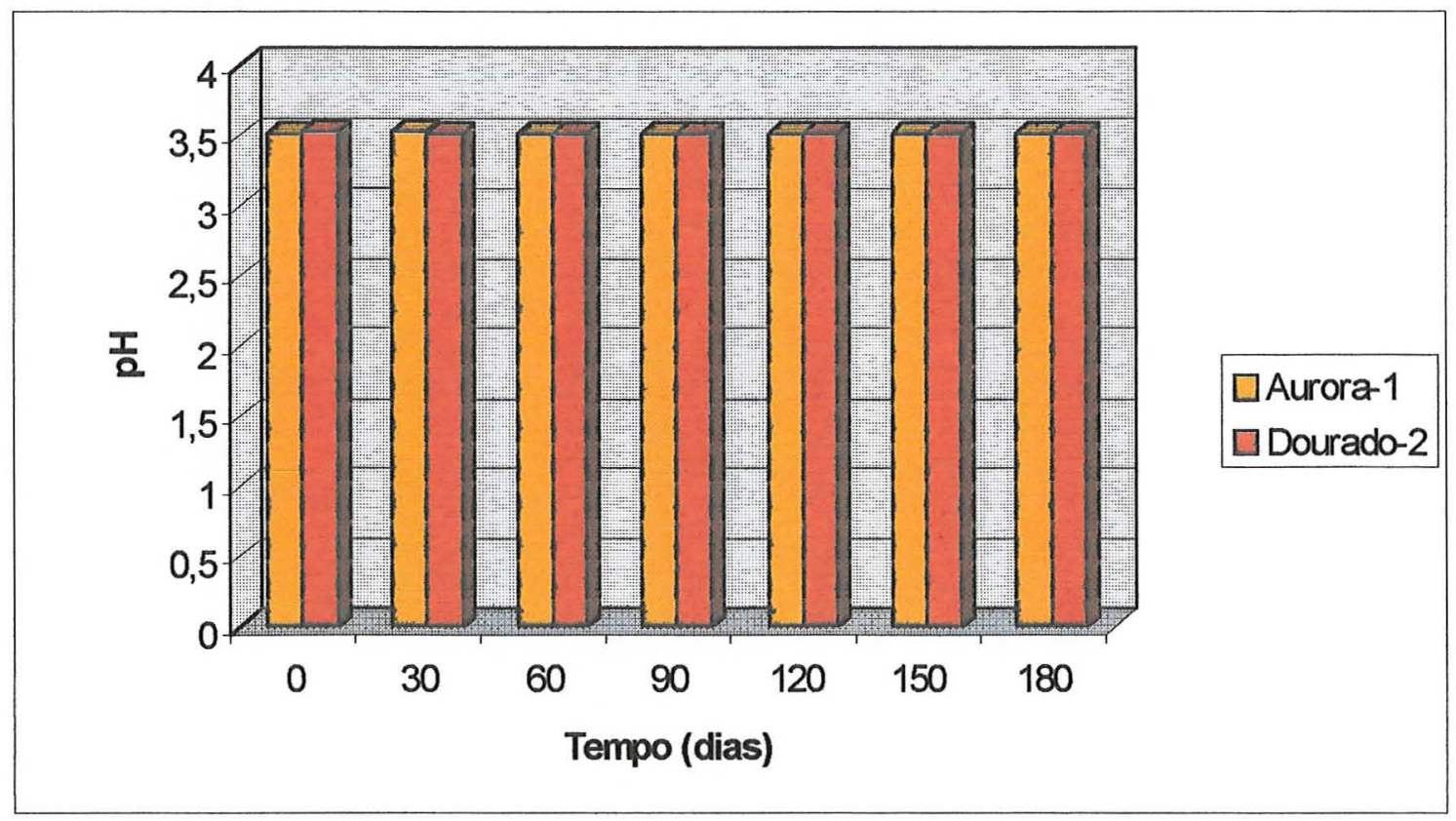

Figura 13 - Variação do $\mathrm{pH}$ dos néctares, em função do tempo de armazenamento 
Goldoni et al. (1981) observaram resultados semelhantes de $\mathrm{pH}$ em sucos pasteurizados de morango, que permaneceram praticamente estáveis ao longo do período de estocagem. Esta estabilidade de $\mathrm{pH}$ por si só já indica uma boa conservação do produto durante o período em que ficou armazenado.

Segundo Chitarra \& Chitarra (1990), numa faixa de concentração de ácido ascórbico entre 2,5 e 0,5\%, o pH aumenta com a redução da acidez, sendo utilizado como indicativo dessa variação, porém, a capacidade tampão de algumas substâncias são responsáveis por grandes variações na acidez titulável, sem variações apreciáveis no $\mathrm{pH}$.

Pela Tabela 9 , observa-se que os valores médios de sólidos solúveis totais, para os néctares, mostraram-se praticamente inalterados em função do tempo de armazenamento. Não foi observada diferença estatística significativa entre tratamentos como também durante o armazenamento, 0 que mostra que as formulações foram bem elaboradas.

Costell et al. (1996), estudando néctares de pêssego de marcas comerciais, encontraram valores médios de $13,5^{\circ} \mathrm{Brix}$, com $45 \%$ de fruta em sua composição.

Comparando-se os valores médios de sólidos solúveis totais dos néctares (Figura 14), observa-se que o cultivar Aurora-1 que apresentou matéria-prima com maior teor de sólidos solúveis, manteve também os néctares-com valores superiores aos da Dourado-2 até o final do armazenamento. Richards (1996), Berbari et al. (1994) e Aggarwal et al. (1992) ao estudarem néctar de pêssego também não observaram mudanças nos valores de sólidos solúveis totais, em produtos armazenados por período de seis meses. 
Tabela 9 - Valores médios de sólidos solúveis totais ( ${ }^{\circ}$ Brix) dos néctares, em função do tempo de armazenamento

Cultivares

Aurora-1 Dourado-2

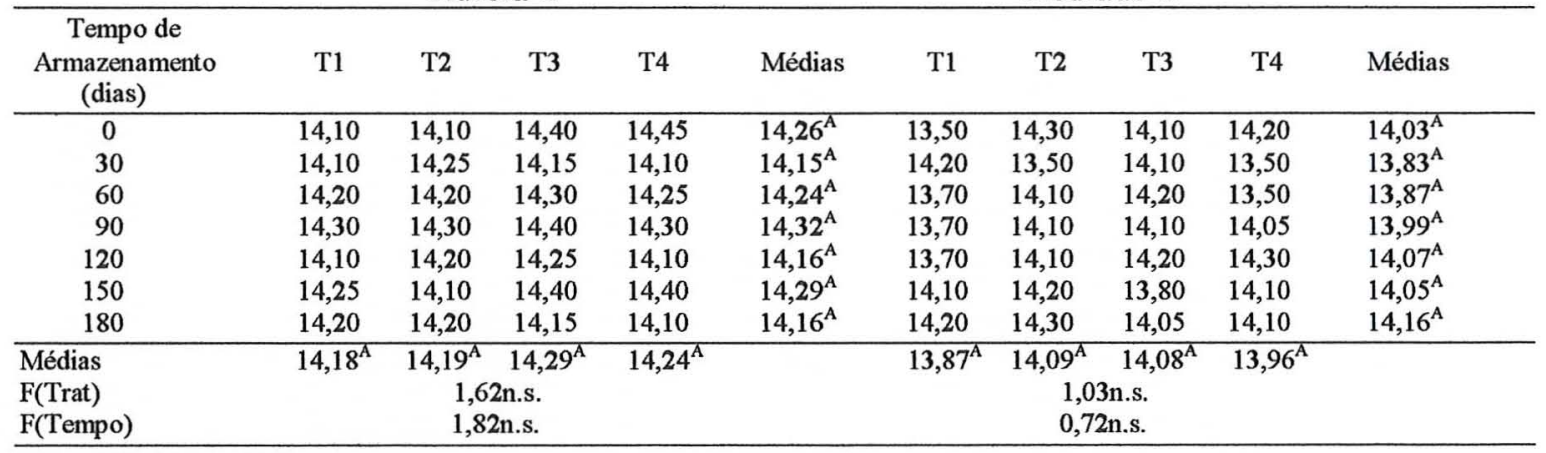

$\mathrm{T} 1, \mathrm{~T} 2, \mathrm{~T} 3$ e $\mathrm{T} 4$ = tratamentos

n.s. = não significativo

Médias com a mesma letra não diferem entre si ao nível de 5\% de significância

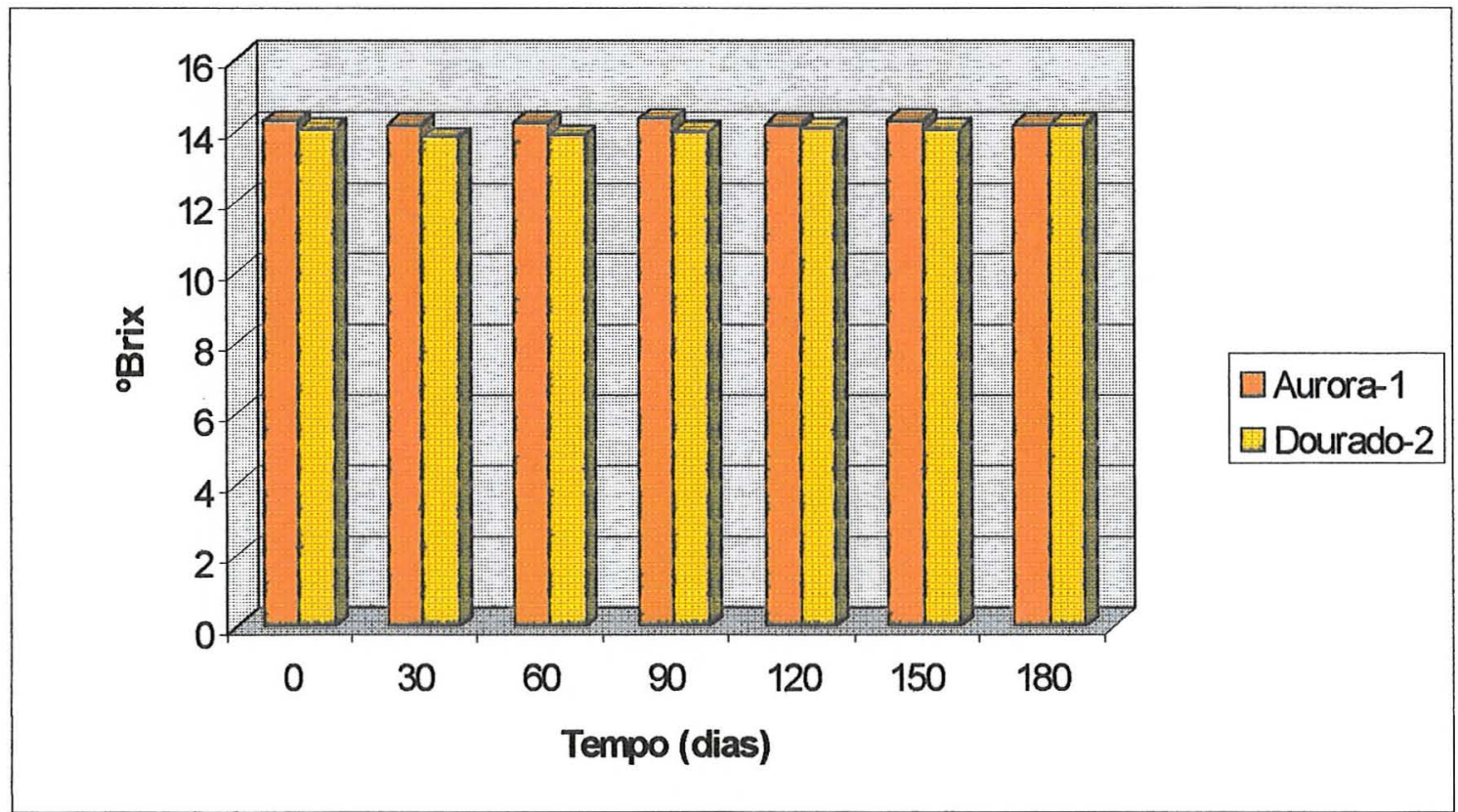

Figura 14 - Variação do teor de sólidos solúveis totais dos néctares, em função do tempo de armazenamento 


\subsection{3 - Análise sensorial}

A avaliação subjetiva da cor dos néctares dos dois cultivares (Tabela 10) mostrou que as menores médias foram dadas aos produtos referentes ao tratamento 4, no qual houve adição de ácido ascórbico. Este tratamento diferiu significativamente dos demais para os dois cultivares estudadas, confirmando os estudos feitos por Askar et al. (1996) e Payumo et al. (1968).

Para Graumlich et al. (1986) a descaracterização da cor é devida à oxidação do ácido ascórbico, responsável pelo escurecimento dos sucos que contém esta vitamina. Estudando suco de acerola, Rocha (1988) verificou que, durante $o$ armazenamento à temperatura ambiente, houve escurecimento e alteração de sabor. Isto explica o escurecimento mais intenso observado no tratamento 4 .

Temperaturas mais baixas proporcionam uma menor degradação do ácido ascórbico bem como dos pigmentos do produto.

Não foi observada diferença estatística significativa para cor durante o armazenamento dos néctares (Tabela 11), porém a Dourado-2 recebeu melhor avaliação quanto a este atributo de qualidade. Isto ocorreu porque a matéria-prima deste cultivar apresenta uma coloração amarela-alaranjada mais intensa (Figura 15).

Para os dois cultivares o melhor tratamento quanto a cor do néctar foi o T2 seguindo-se o T3, T1 e T4 (Figura 15).

Em relação à consistência, os tratamentos não diferiram estatisticamente entre si (Tabela 10), porém pela Tabela 11 observa-se que com o tempo de armazenamento as notas médias para o atributo consistência diminuíram. Este decréscimo, entretanto, foi estatisticamente significativo somente para o cultivar Aurora-1 aos 90 dias de armazenamento. 
Tabela 10 - Valores médios das análises sensoriais dos néctares, em função dos tratamentos

Cultivares

Aurora-1

Dourado-2

\begin{tabular}{ccccccc}
\hline TRATAMENTOS & COR & CONSIST. & SABOR & COR & CONSIST. & SABOR \\
\hline T1 & $4,25^{\mathrm{B}}$ & $5,92^{\mathrm{A}}$ & $5,54^{\mathrm{B}}$ & $7,13^{\mathrm{A}}$ & $6,42^{\mathrm{A}}$ & $6,88^{\mathrm{AB}}$ \\
T2 & $8,04^{\mathrm{A}}$ & $6,96^{\mathrm{A}}$ & $6,29^{\mathrm{A}}$ & $8,38^{\mathrm{A}}$ & $7,05^{\mathrm{A}}$ & $7,13^{\mathrm{A}}$ \\
T3 & $6,59^{\mathrm{B}}$ & $7,17^{\mathrm{A}}$ & $6,33^{\mathrm{A}}$ & $7,71^{\mathrm{A}}$ & $7,29^{\mathrm{A}}$ & $7,25^{\mathrm{A}}$ \\
T4 & $3,71^{\mathrm{C}}$ & $6,71^{\mathrm{A}}$ & $5,21^{\mathrm{B}}$ & $6,17^{\mathrm{B}}$ & $6,79^{\mathrm{A}}$ & $5,34^{\mathrm{B}}$ \\
\hline F(Trat) & $18,64^{*}$ & 4,41 n.s. & $5,21^{*}$ & $8,04^{*}$ & 6,35 n.s. & $3,46^{*}$ \\
F(Cultivares) & $59,38^{*}$ & $5,40^{*}$ & $15,14^{*}$ & $59,38^{*}$ & $5,40^{*}$ & $15,14^{*}$ \\
\hline
\end{tabular}

n.s. =não significativo

$*$ = significativo ao nível de $5 \%$

Médias com a mesma letra, ao longo de cada coluna, não diferem entre si ao nível de $5 \%$ de significância

Tabela 11 - Valores médios das análises sensoriais dos néctares, em função do tempo de armazenamento

Cultivares

Aurora-1

Dourado-2

\begin{tabular}{ccccccc}
\hline & & & & & \\
TEMPO (dias) & COR & CONSIST & S.ABOR & COR & CONSIST. & SABOR \\
\hline 30 & $6.53^{A}$ & $7,57^{A}$ & $6.32^{A}$ & $8.00^{A}$ & $7,19^{A}$ & $7,19^{A}$ \\
60 & $5.82^{A}$ & $6.75^{A}$ & $5.82^{A}$ & $7.53^{A}$ & $6,94^{A}$ & $6,75^{A}$ \\
90 & $4.85^{A}$ & $5,78^{\mathrm{B}}$ & $5.50^{A}$ & $6.25^{A}$ & $6,47^{A}$ & $5,91^{A}$ \\
\hline F(Tempo) & 0.37 n.s. & $4,50^{\circ}$ & 1.93 n.s. & 2.16 n.s. & 1,97 n.s. & 1,79 n.s. \\
\hline
\end{tabular}

n.s. = não significativo

$*$ = significativo ao nível de $5 \%$

Médias com a mesma letra, no sentido vertical, não diferem entre si ao nível de $5 \%$ de significância

Dentre os néctares estudados (Figura 16), verifica-se que a Dourado-2 resultou em um produto com melhor consistência. Isto deve ter ocorrido pelo fato da Aurora-1 conter um teor de pectina bem maior que a Dourado-2, proporcionando que o néctar desta última tenha uma consistência mais fluída e por isto mais apreciado. Este teor maior de pectina pode ser inferido dos 


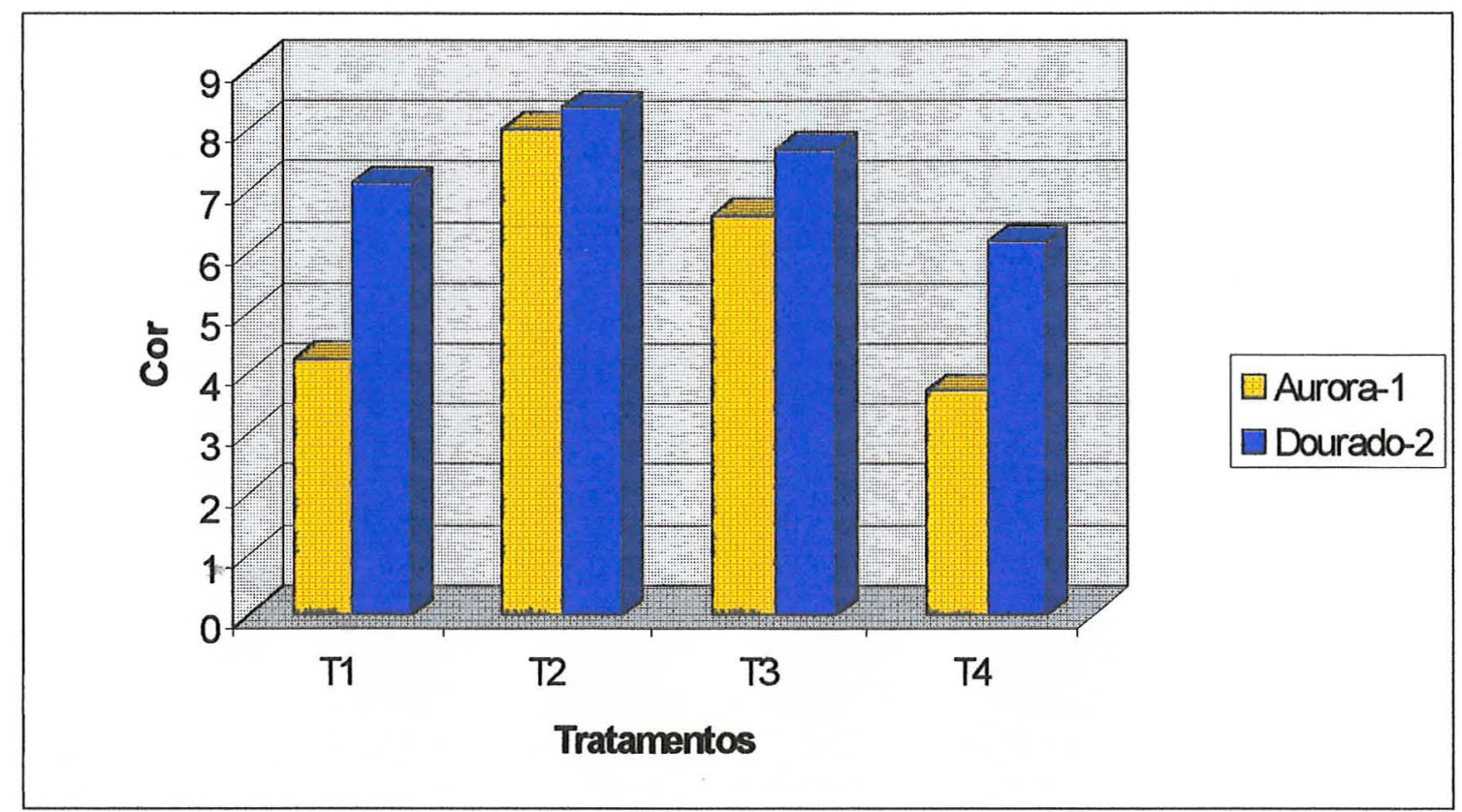

Figura 15 - Valores médios das notas obtidas na avaliação sensorial, quanto à cor dos néctares

valores de textura (Tabela 1) onde se observa que a Aurora-1 é três vezes mais firme que a Dourado-2.

Como mostra a Tabela 10 e Figura 17, T2 e T3 foram avaliados como os melhores tratamentos quanto ao sabor devendo-se essa preferência pela utilização da refrigeração (T2) e pela adição do sorbato de potássio (T3) que proporcionaram um produto de maior estabilidade microbiana, obtendo-se assim um néctar mais agradável e saboroso. 


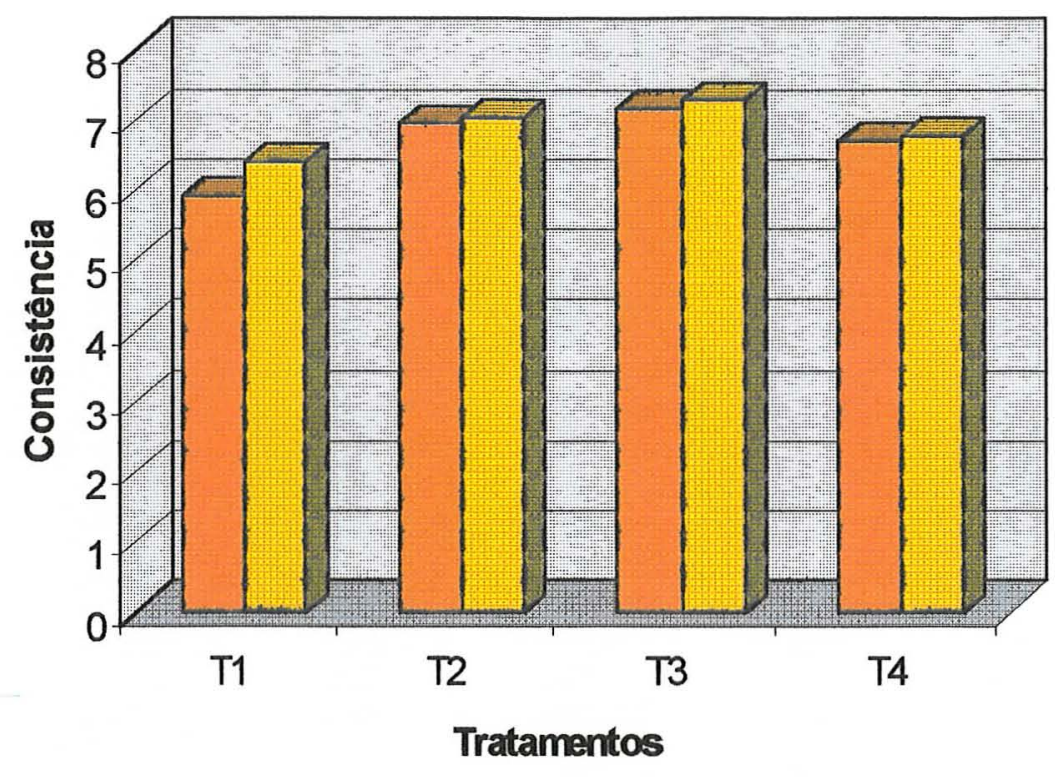

口Aurora-1

DDourado-2

Figura 16 - Valores médios das notas obtidas na avaliação sensorial, quanto à consistência dos néctares

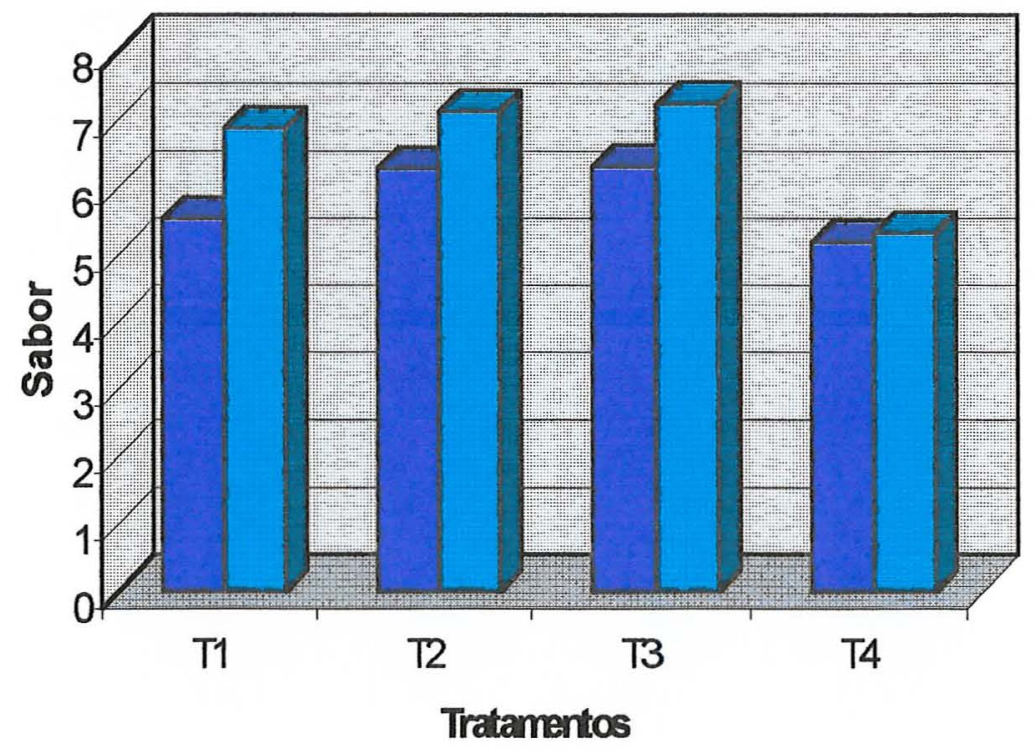

Aurora-1

DDourado-2

Figura 17 - Valores médios das notas obtidas na avaliação sensorial, quanto ao sabor dos néctares 
Comparando os dois cultivares (Figura 18), pode-se observar que de um modo geral, os néctares do cultivar Dourado-2 foram superiores aos da Aurora-1 em todos atributos de qualidade durante os 90 dias de armazenamento.

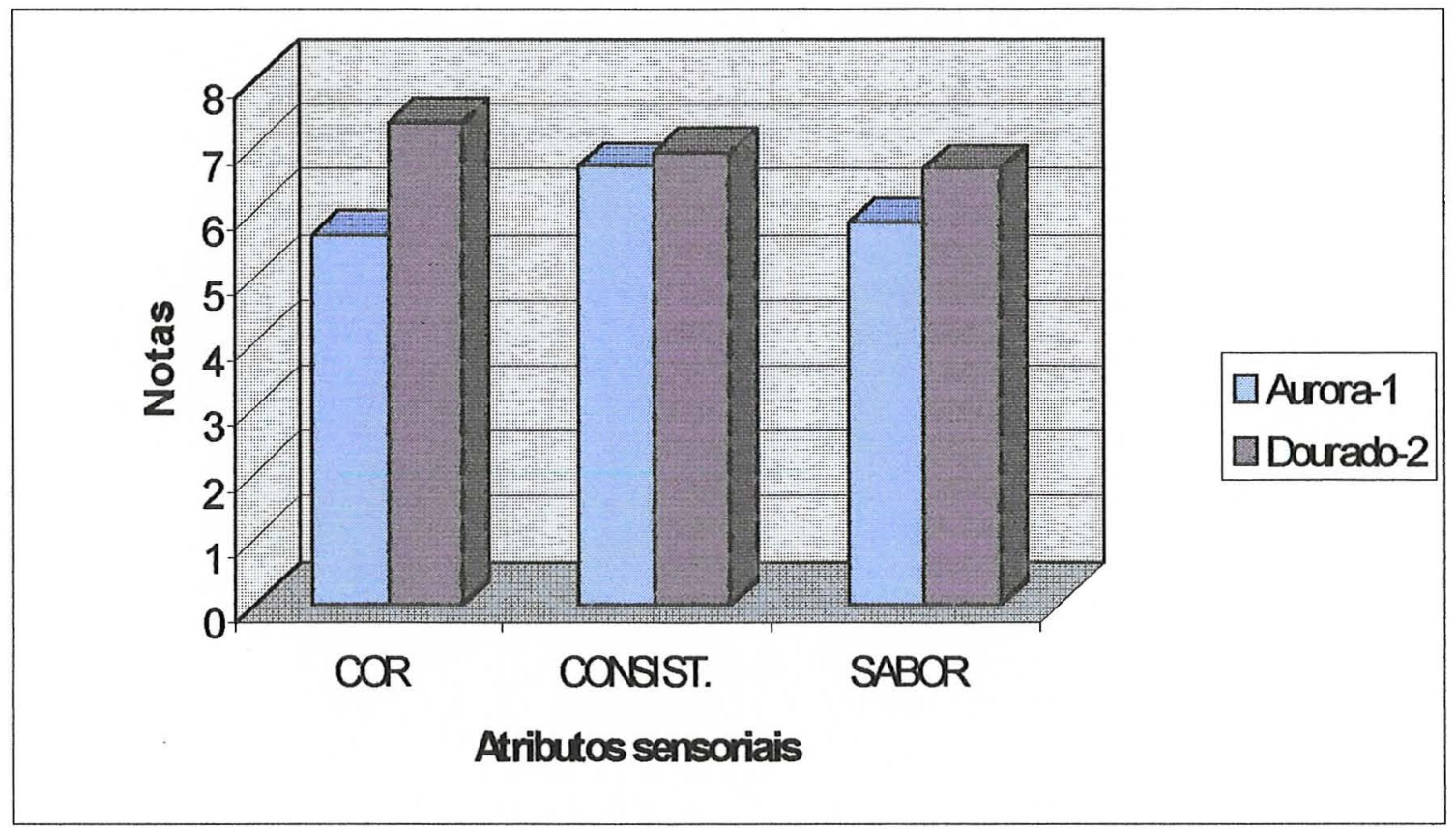

Figura 18 - Valores médios das notas obtidas na avaliação sensorial, quanto aos atributos de qualidade dos néctares

\section{3 - Caracterização do néctar light}

\subsection{1 - Análise física}

Os resultados dos valores médios de vácuo das latas dos néctares light dos cultivares Aurora-1 e Dourado-2 são apresentados na Tabela 12. Para ambos cultivares os valores médios de vácuo encontrados estão adequados (entre 8 e 15 pol.Hg), conforme recomenda Martin (1965/66), não apresentando variações significativas, indicando uma boa estabilidade do produto, o que é benéfico e desejável. 
Tabela 12 - Valores médios de vácuo (pol.Hg) das latas dos néctares light, em função do tempo de armazenamento

\section{Cultivares}

\section{Aurora-1}

Dourado-2

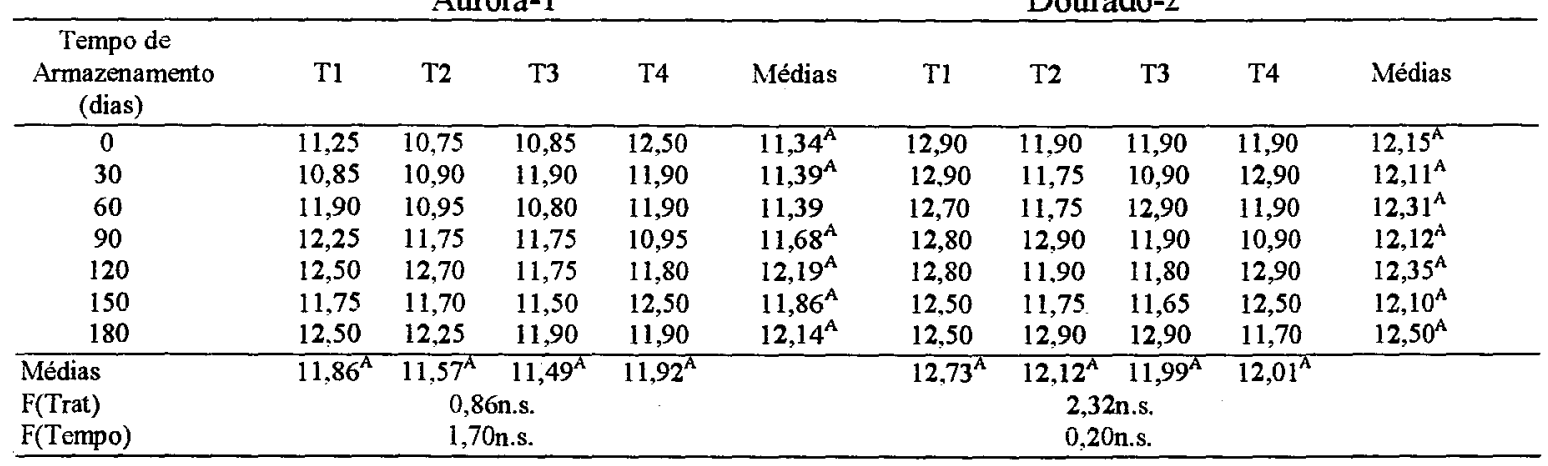

$\mathrm{T} 1, \mathrm{~T} 2, \mathrm{~T} 3$ e $\mathrm{T} 4=$ Tratamentos

n.s. = não significativo

Médias com a mesma letra não diferem entre si ao nível de $5 \%$ de significância

Alves \& Garcia (1993) e Uboldi Eiroa (1989), observaram que a estabilidade dos sucos e néctares de frutas, quando resolvidos os aspectos microbiológicos e enzimáticos, é determinada pela ocorrência de reações químicas, na maioria oxidativas, modificando as suas características organolépticas e também o seu valor nutritivo. Os autores relatam ainda que a embalagem deve ter formato e resistência físico-mecânica ideais, para que não ocorra deformações devido às condições de processamento e aos níveis de vácuo formado após o resfriamento/congelamento. Pode-se dizer, portanto que a embalagem utilizada em produtos submetidos à pasteurização ou enchimento a quente, deve ter resistência mecânica e térmica para suportar as temperaturas empregadas no processamento.

Richards (1996) e Askar et al. (1993) estudando néctar de manga afirmam que, a desaeração e o enchimento das latas a quente, são mecanismos essenciais para se obter redução da quantidade de oxigênio nos 
néctares. Pelos resultados aqui obtidos (Tabela 12) pode-se concluir que esse objetivo foi alcançado.

Nas Tabelas 13 e 14 estão relacionados os pesos bruto e líquido das latas dos néctares de ambos cultivares, cujos valores foram bem uniformes, não apresentando diferenças estatísticas significativas entre tratamentos. Já em relação ao período de armazenamento as diferenças foram significativas para a Aurora-1 (peso bruto) e para ambos os cultivares (peso líquido). Com essa uniformidade, que não é afetada pelas variações estatísticas, pode-se inferir que o preenchimento das latas dos néctares light foi efetuado de maneira adequada, garantindo assim um produto final com boa qualidade do ponto de vista físico.

\subsection{2 - Análise química}

$\mathrm{Na}$ Tabela 15 são apresentados os valores de ácido ascórbico dos néctares light dos cultivares Aurora-1 e Dourado-2. Observa-se que ao longo do período de armazenamento, as perdas de ácido ascórbico não foram estatisticamente significativas, preservando ao final de 180 dias um razoável teor da vitamina. Em relação aos tratamentos dos néctares em questão, somente o T4 (que recebeu adição de ácido ascórbico) diferiu dos demais tratamentos, sendo este um fato esperado. A Figuras 19 e 20 mostram o perfil de redução do teor de ácido ascórbico respectivamente dos néctares dos cultivares Aurora-1 e Dourado-2, em função do tempo de armazenamento.

Essa redução nos valores de ácido ascórbico foi também constatada por Aggarwal et al. (1992), Aradhita et al. (1995), Askar et al. (1996) e Díez et al. (1995) em néctares de pêssego, goiaba, manga e abacaxi, ao longo do período de armazenamento. 
Tabela 13 - Valores médios do peso bruto $(\mathrm{g})$ das latas dos néctares light, em função do tempo de armazenamento

\section{Cultivares}

Aurora-1 Dourado-2

\begin{tabular}{|c|c|c|c|c|c|c|c|c|c|c|}
\hline $\begin{array}{c}\text { Tempo de } \\
\text { Armazenamento } \\
\text { (dias) }\end{array}$ & $\mathrm{T} 1$ & $\mathrm{~T} 2$ & $\mathrm{~T} 3$ & $\mathrm{~T} 4$ & Médias & $\mathrm{T} 1$ & $\mathrm{~T} 2$ & $\mathrm{~T} 3$ & $\mathrm{~T} 4$ & Médias \\
\hline 0 & 409.8 & 403,3 & 400,9 & 401,7 & $403,9^{\mathrm{B}}$ & 407.3 & 406,4 & 408,4 & 409,1 & $407,8^{\mathrm{A}}$ \\
\hline 30 & 414,8 & 413,3 & 408,5 & 408,5 & $411,3^{A}$ & 404.6 & 395,8 & 412,8 & 405,0 & $404,5^{A}$ \\
\hline 60 & 414.2 & 415,9 & 416,8 & 419,7 & $416,6^{A}$ & 401,4 & 409,8 & 403,7 & 408,8 & $405,9^{A}$ \\
\hline 90 & 411,7 & 410,2 & 405,4 & 408,2 & $408,9^{\mathrm{B}}$ & 408.5 & 415,2 & 412,5 & 411,2 & $411,8^{A}$ \\
\hline 120 & 404.6 & 406,2 & 416,3 & 413,3 & $410,1^{A}$ & 407.5 & 408.1 & 402,9 & 408,0 & $406,6^{\mathrm{A}}$ \\
\hline & 410.7 & 408,8 & 406,6 & 408,0 & $408,5^{\mathrm{B}}$ & 408.4 & 402,5 & 411,1 & 404,6 & $406,7^{A}$ \\
\hline 180 & 409.1 & 407,2 & 407,5 & 407,7 & $407.9^{\mathrm{B}}$ & 403,2 & 412,5 & 407,6 & 407,2 & $407,6^{A}$ \\
\hline Médias & $410,7^{\mathrm{A}}$ & $409,3^{A}$ & $408,9^{A}$ & $409.6^{A}$ & & $405.8^{A}$ & $407.2^{A}$ & $408,4^{A}$ & $407,7^{\mathrm{A}}$ & \\
\hline $\begin{array}{l}\text { F(Trat) } \\
\text { F(Tempo) }\end{array}$ & \multicolumn{4}{|c|}{$\begin{array}{l}0.18 \text { n.s. } \\
5.60^{*}\end{array}$} & \multicolumn{6}{|c|}{$\begin{array}{l}0,47 \mathrm{n} . \mathrm{s} . \\
1,34 \mathrm{n} . \mathrm{s} .\end{array}$} \\
\hline
\end{tabular}

$\mathrm{T} 1, \mathrm{~T} 2, \mathrm{~T} 3 \mathrm{e} \mathrm{T} 4=$ tratamentos

$*$ = significativo ao nível de $5 \%$

n.s. = não significativo

Médias com a mesma letra não diferem entre si ao nível de $5 \%$ de significância

Tabela 14 - Valores médios do peso líqüido (g) das latas dos néctares light, em função do tempo de armazenamento

Cultivares

Aurora-1 Dourado-2

\begin{tabular}{|c|c|c|c|c|c|c|c|c|c|c|}
\hline $\begin{array}{l}\text { Tempo de } \\
\text { Armazenamento } \\
\text { (dias) }\end{array}$ & $\mathrm{T} 1$ & $\mathrm{~T} 2$ & $\mathrm{~T} 3$ & $\mathrm{~T} 4$ & Médias & $\mathrm{T} 1$ & $\mathrm{~T} 2$ & $\mathrm{~T} 3$ & T4 & Médias \\
\hline 0 & 353.8 & 347,3 & 344,8 & 345,6 & $347,9^{\circ}$ & 351.2 & 350,3 & 352,3 & 353,0 & $351,7^{\mathrm{C}}$ \\
\hline 30 & 365,5 & 364,0 & 359,2 & 359,2 & $362,0^{\mathrm{AB}}$ & 355.3 & 345,7 & 363,5 & 355,7 & $355,1^{\mathrm{BC}}$ \\
\hline 60 & 365.3 & 366,3 & 367,2 & 370,8 & $367,4^{A}$ & 352.5 & 360.2 & 354,1 & 359,9 & $356,7^{\mathrm{AB}}$ \\
\hline 90 & 362,0 & 360.5 & 355,7 & 358.5 & $359,2^{\mathrm{AB}}$ & 358.8 & 365.5 & 362,8 & 361,5 & $362.2^{\mathrm{AB}}$ \\
\hline 120 & 364,2 & 366.2 & 350,3 & 363.6 & $361,1^{\mathrm{AB}}$ & 369.3 & 358.0 & 361,3 & 361,9 & $362,6^{\mathrm{AB}}$ \\
\hline 150 & 362.3 & 360,8 & 362,4 & 362,2 & $361.9^{A B}$ & 361.7 & 364.4 & 365,2 & 359,9 & $362,8^{A B}$ \\
\hline 180 & 365.3 & 364,4 & 361,7 & 360.6 & $363,0^{A B}$ & 361.8 & 367.4 & 365,5 & 368,2 & $365,7^{A}$ \\
\hline Médias & 362.6 & $361.4^{A}$ & $357,3^{A}$ & $360.1^{A}$ & & $358.6^{A}$ & $358,8^{\lambda}$ & $360,7^{\mathrm{A}}$ & $360,0^{A}$ & \\
\hline $\mathrm{F}($ Trat $)$ & \multirow{2}{*}{\multicolumn{4}{|c|}{$\begin{array}{l}0.8 \ln . s . \\
10.36^{*}\end{array}$}} & \multirow{2}{*}{\multicolumn{6}{|c|}{$\begin{array}{l}0.17 \mathrm{n} . \mathrm{s} \\
6.30^{*}\end{array}$}} \\
\hline F(Tempo) & & & & & & & & & & \\
\hline
\end{tabular}

$\mathrm{T} 1, \mathrm{~T} 2, \mathrm{~T} 3$ e $\mathrm{T} 4=$ tratamentos

* = significativo ao nível de $5 \%$

n. s. = não significativo

Médias com a mesma letra não diferem entre si ao nível de $5 \%$ de significância 
Tabela 15 - Valores médios dos teores de ácido ascórbico (mg/100g) dos néctares light, em função do tempo de armazenamento

Cultivares

Aurora-1 Dourado-2

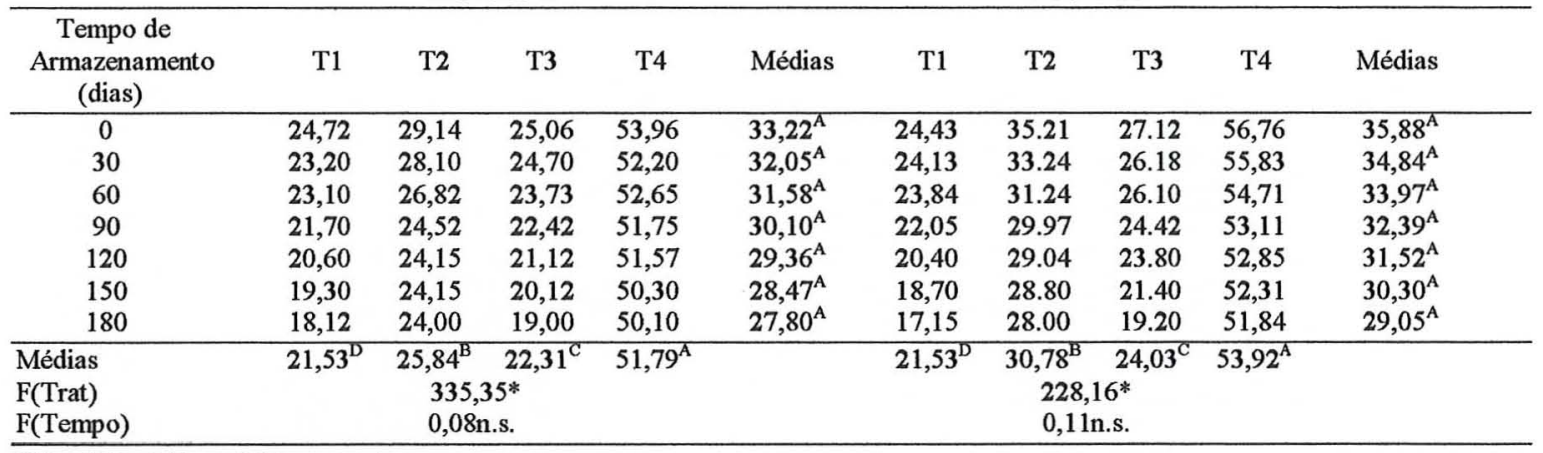

$\mathrm{T} 1, \mathrm{~T} 2, \mathrm{~T} 3$ e $\mathrm{T} 4$ = tratamentos

* = significativo ao nível de 5\%

n.s. = não significativo

Médias com a mesma letra não diferem entre si ao nível de $5 \%$ de significância

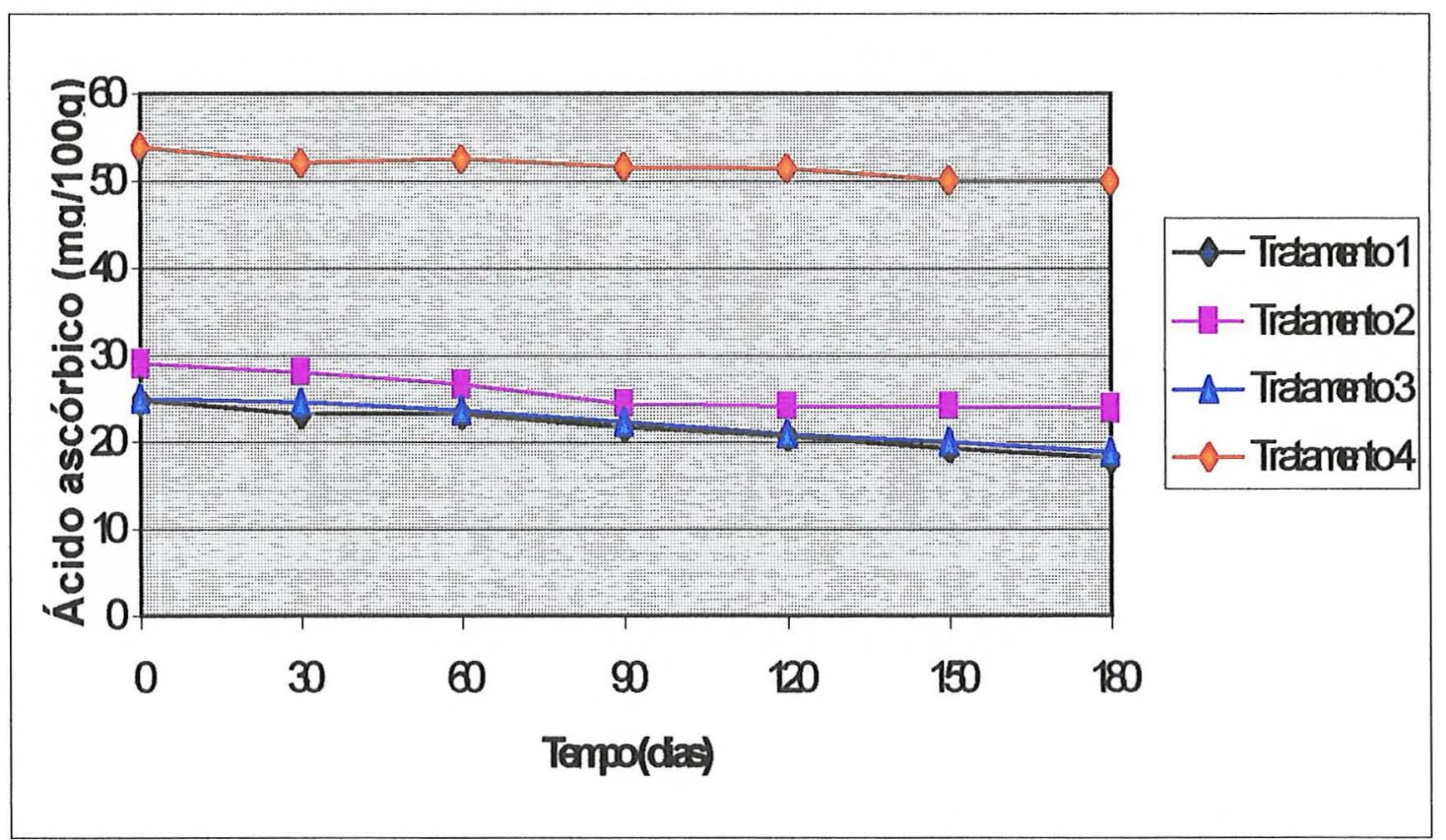

Figura 19 - Variação do teor de ácido ascórbico dos néctares light da Aurora-1, em função do tempo de armazenamento 


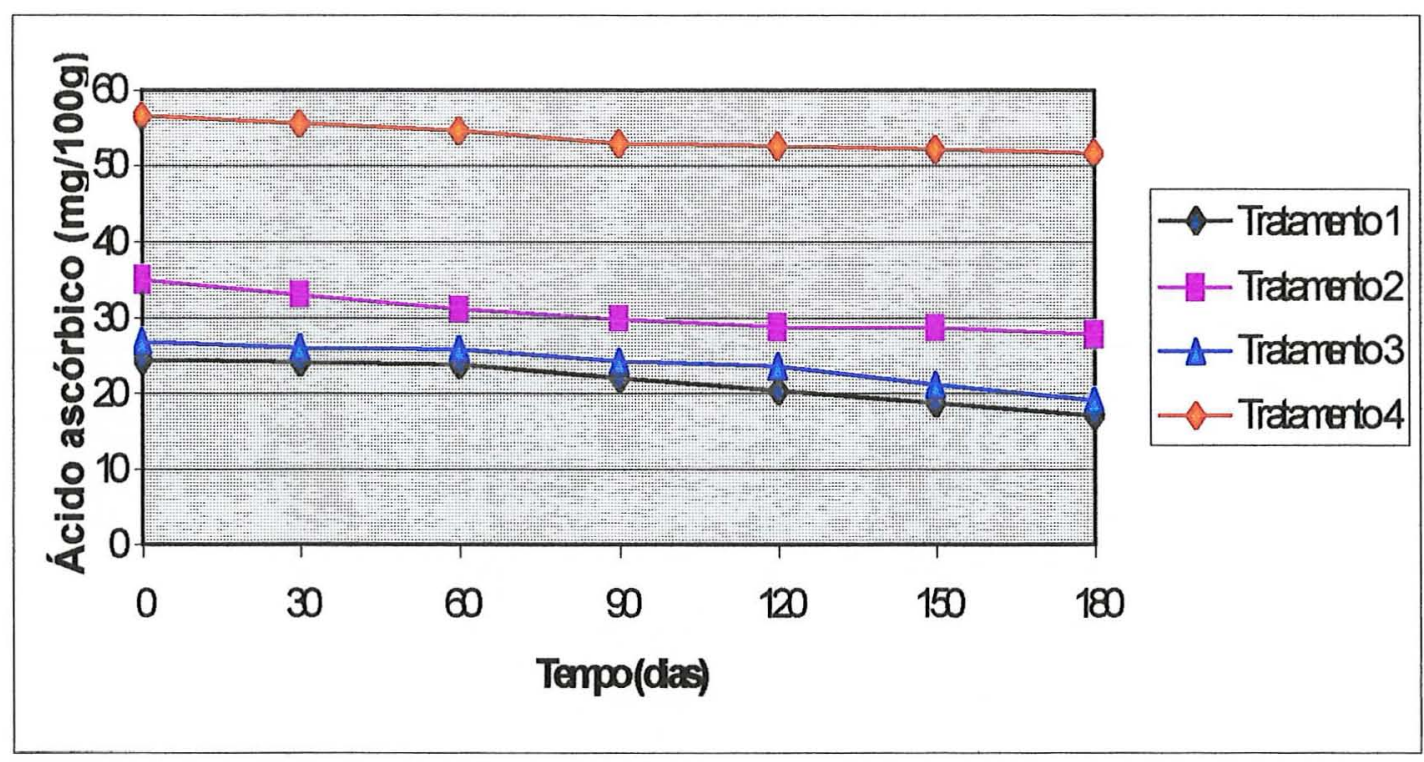

Figura 20 - Variação do teor de ácido ascórbico dos néctares light da Dourado-2, em função do tempo de armazenamento

A adição de ácido cítrico em todos os tratamentos deve ter contribuído para tornar as perdas de ácido ascórbico menos acentuadas em todo o período de armazenamento. Hudson et al. (1975) trabalhando com morangos congelados e Novaes (1997) com néctar de morango de fato constataram que a adição de ácido cítrico melhora a retenção da vitamina durante o armazenamento dos produtos.

Comparando-se os teores de ácido ascórbico, dos néctares dos dois cultivares (Figura 21), pode-se observar que como aconteceu no néctar, o cultivar Dourado-2 apresentou valores mais elevados desta vitamina, ao longo do período de armazenamento. 


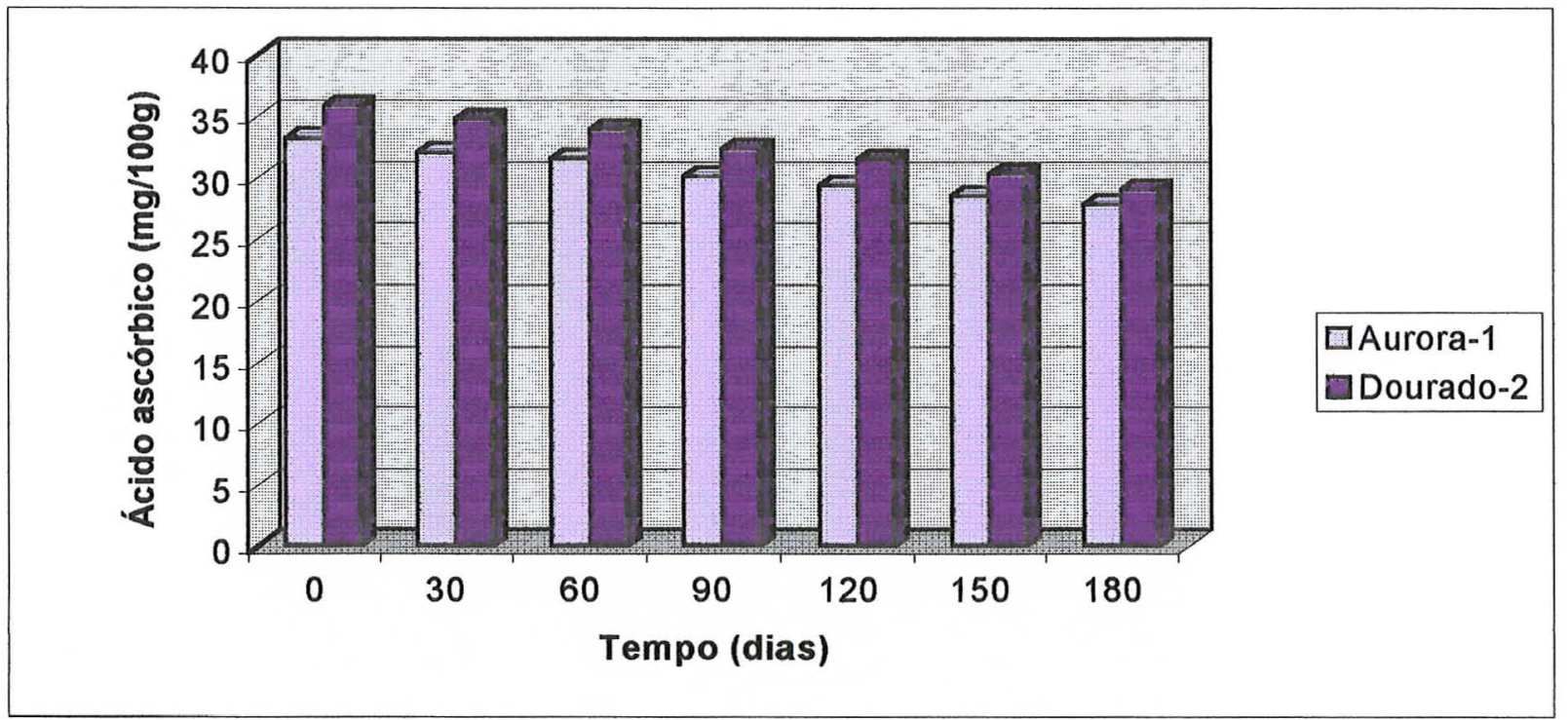

Figura 21 - Variação dos teor de ácido ascórbico dos néctares light, em função do tempo de armazenamento

A Tabela 15 e Figura 21 mostram que após 180 dias de armazenamento ocorreu, para os tratamentos, perdas de ácido ascórbico na seguinte ordem: T1 - 26,70\%, T3 - 24,18\%, T2 - 17,64\%, T4 - 7,15\% (Aurora-1) e T1 - 29,80\%, T3 - 29,20\%, T2 - 20,48\%, T4 - 8,67\% (Dourado2).

Nota-se que a menor perda de ácido ascórbico durante $o$ armazenamento dos dois cultivares foi para o tratamento 4. Analisando a Tabela 15 e as Figuras 19 e 20, observa-se que dentre os tratamentos que não receberam adição de ácido ascórbico, o T2 foi o que apresentou a menor perda desta vitamina, devendo-se esse fato ao armazenamento refrigerado.

Oliva et al. (1996) estudando a estabilidade do néctar de acerola observaram resultados semelhantes para o armazenamento a temperatura ambiente (27\% de perda), porém encontraram resultados menores para o armazenamento refrigerado (7,78\%). Também foi verificado por De Martin 
et al. (1972) a redução de $26 \%$ no teor de ácido ascórbico em néctar de mamão armazenado à temperatura ambiente.

Considerando que o consumidor atual está cada vez mais exigente, o produto enriquecido com vitamina $C$, faz com que seja mais atrativo e por conseqüência mais aceito no mercado interno e externo.

A Tabela 16 mostra que os teores médios de acidez total titulável dos néctares, diminuíram durante o armazenamento, porém esta redução não foi estatisticamente significativa.

Os néctares do cultivar Dourado-2 apresentaram acidez maior que os da Aurora-1 (Figuras 22 e 23). Este fato também ocorreu nos néctares comuns, mostrando novamente que a matéria-prima com maior teor de acidez (Dourado-2), originou néctares também mais ácidos (Figura 24).

A diminuição de acidez, durante o armazenamento foi também observada por Novaes (1997), fato que se atribui à diminuição do teor de ácido ascórbico, já que este faz parte da acidez total. Já Baramanray et al. (1995) estudando néctares de goiaba observaram aumento de acidez durante o armazenamento. Isto ocorre devido à transformação de açúcares em ácidos orgânicos por leveduras, sendo portanto indicação de má conservação do produto.

Os resultados dos valores médios de $\mathrm{pH}$ dos néctares light, estão apresentados na Tabela 17 , onde se observa que não houve variações estatísticas significativas nem para os tratamentos e nem para o período de armazenamento. Essa estabilidade no $\mathrm{pH}$ se deve ao fato de que todos os tratamentos tiveram adição de ácido cítrico para ter $\mathrm{pH}$ de equilíbrio $\mathrm{em}$ torno de 3,5-3,6 (Figura 25). Resultados semelhantes foram obtidos por 
Tabela 16 - Valores médios de acidez total titulável (g ácido cítrico/100g) dos néctares light, em função do tempo de armazenamento

Cultivares

Aurora-1

Dourado-2

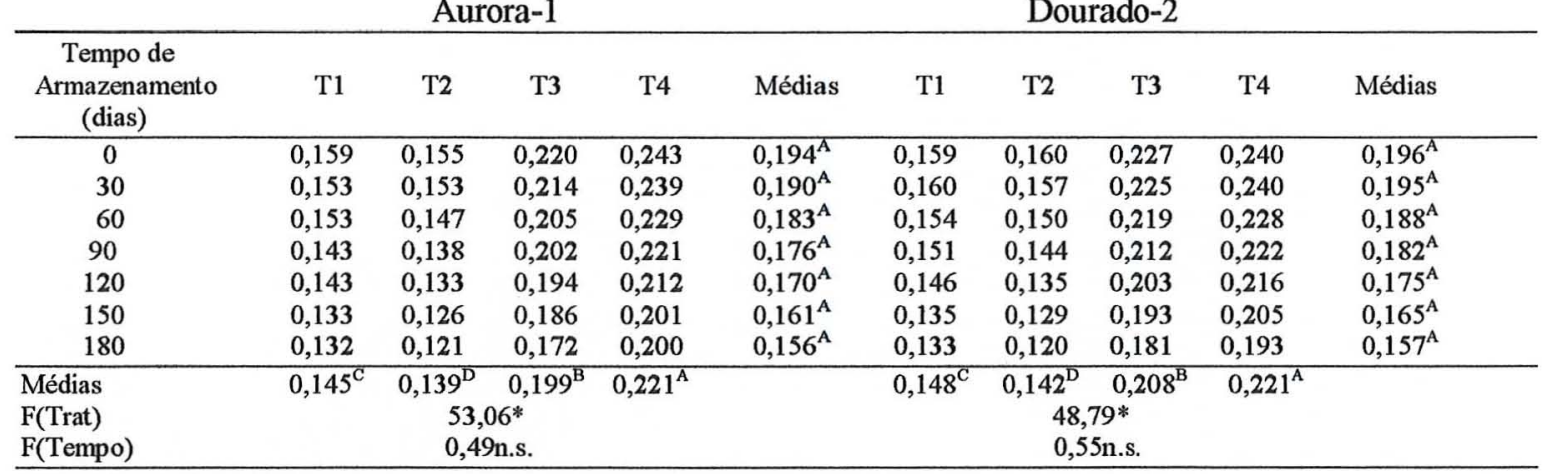

$\mathrm{T} 1, \mathrm{~T} 2, \mathrm{~T} 3$ e $\mathrm{T} 4=$ tratamentos

* = significativo ao nível de $5 \%$

$\mathrm{n} . \mathrm{s} .=$ não significativo

Médias com a mesma letra não diferem entre si ao nível de 5\% de significância

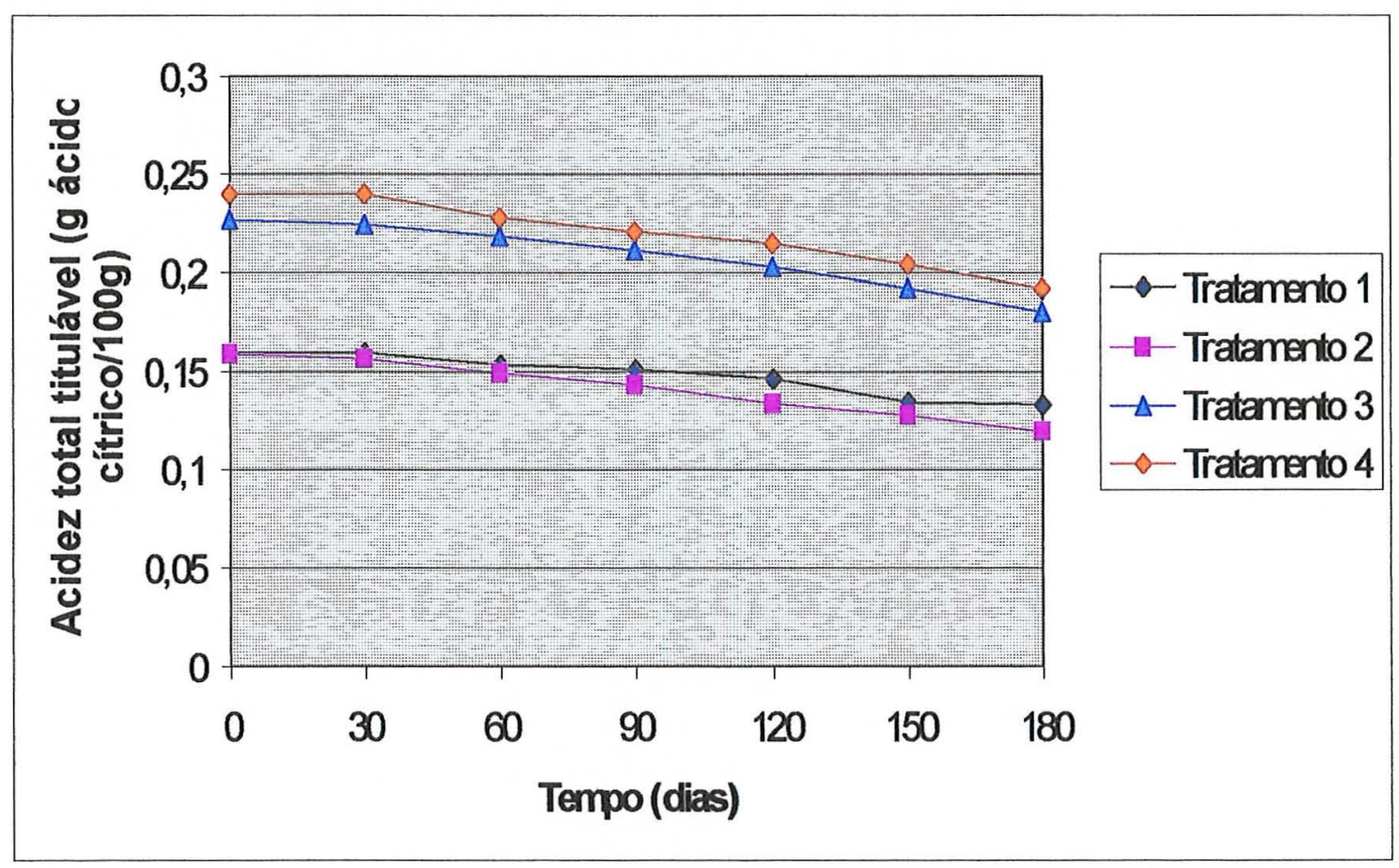

Figura 22 - Variação da acidez total titulável dos néctares light da Aurora-1, em função do tempo de armazenamento 


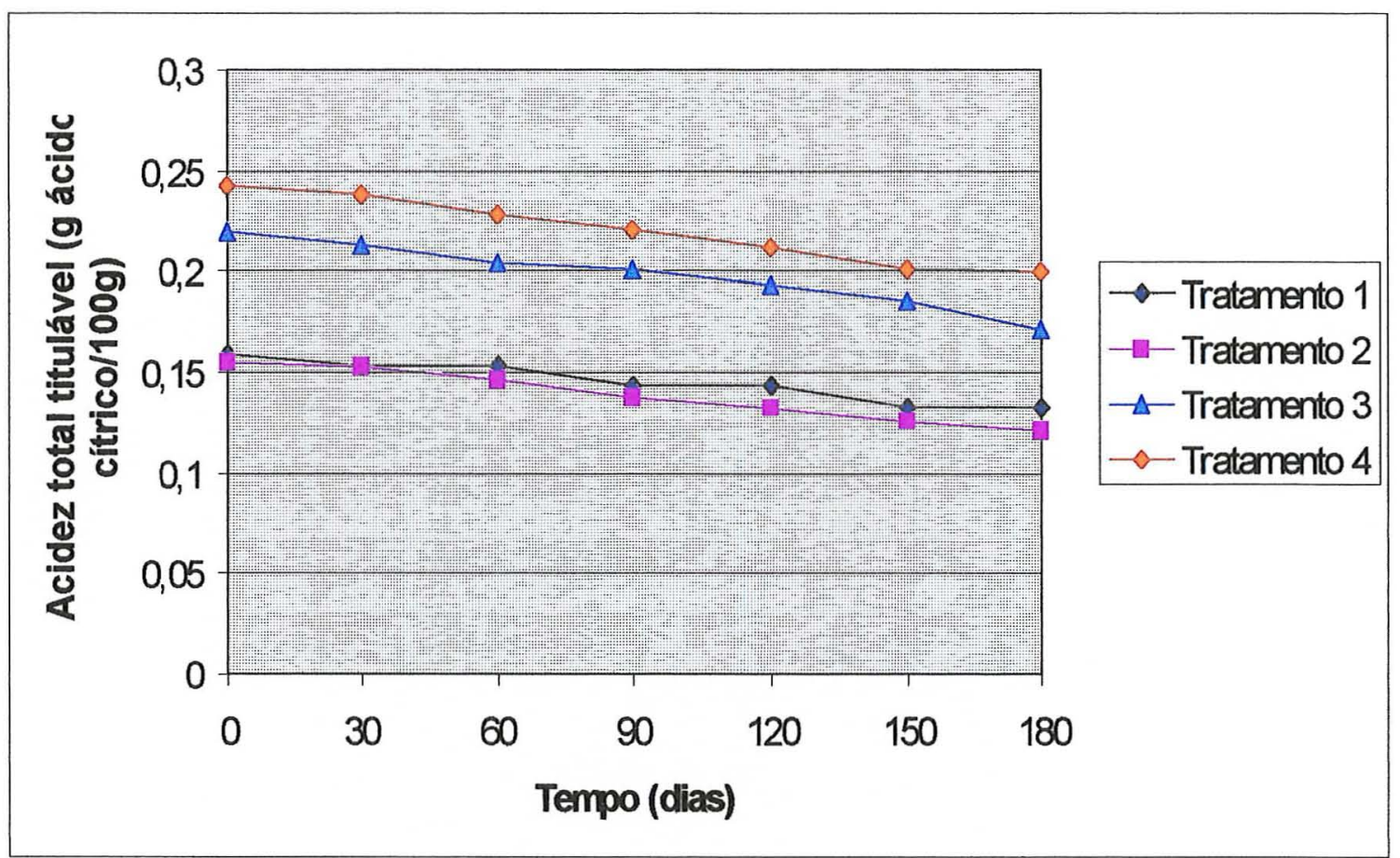

Figura 23 - Variação da acidez total titulável dos néctares light da Dourado-2, em função do tempo de armazenamento

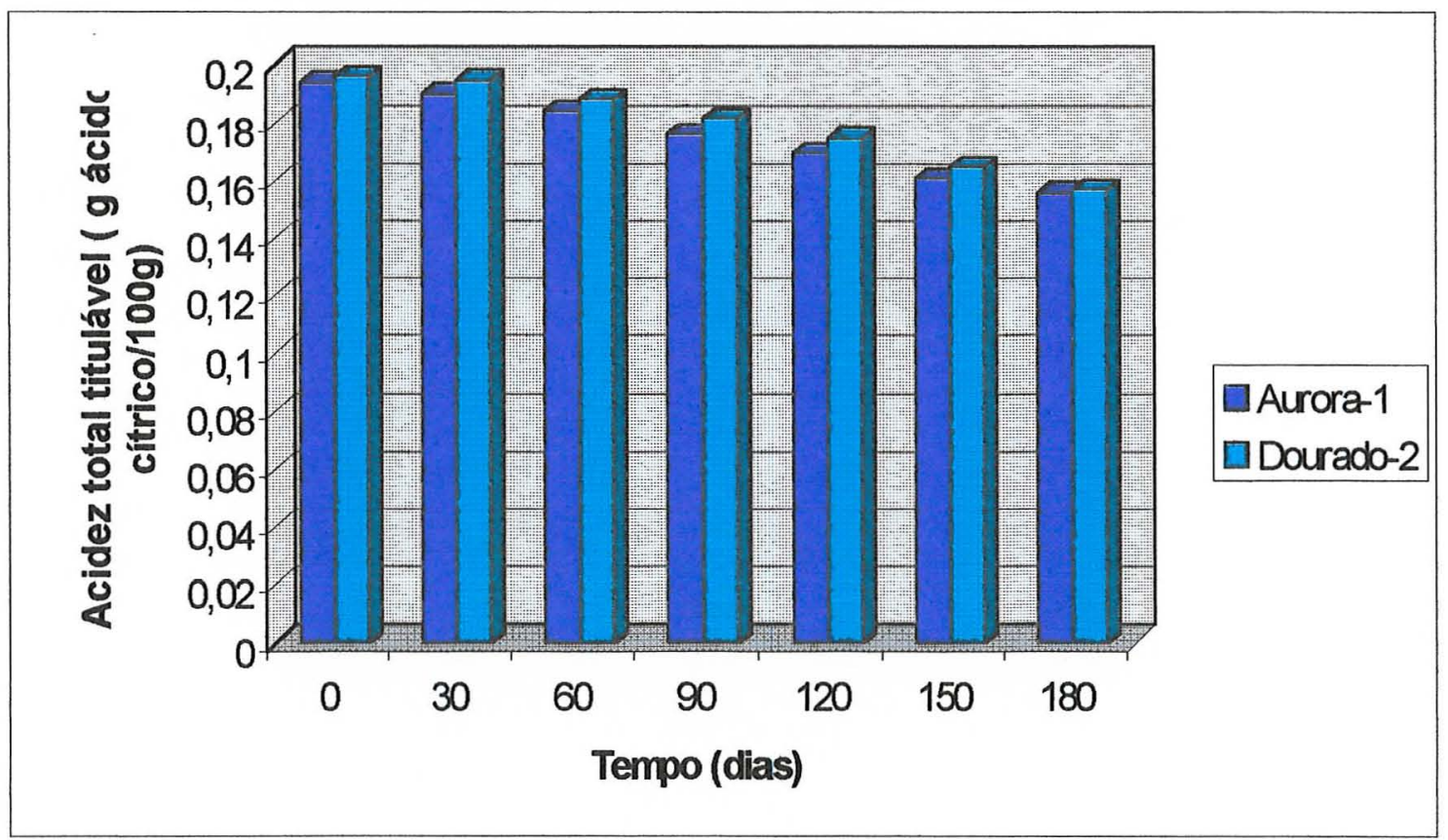

Figura 24 - Variação da acidez total titulável dos néctares light, em função do tempo de armazenamento 
Tabela 17 - Valores médios de $\mathrm{pH}$ dos néctares light, em função do tempo de armazenamento

\section{Cultivares}

Aurora-1

Dourado-2

\begin{tabular}{|c|c|c|c|c|c|c|c|c|c|c|}
\hline $\begin{array}{c}\text { Tempo de } \\
\text { Armazenamento } \\
\text { (dias) }\end{array}$ & $\mathrm{T} 1$ & $\mathrm{~T} 2$ & T3 & $\mathrm{T} 4$ & Médias & $\mathrm{T} 1$ & $\mathrm{~T} 2$ & T3 & $\mathrm{T} 4$ & Médias \\
\hline 0 & 3,60 & 3,60 & 3,60 & 3,60 & $3,60^{A}$ & 3,60 & 3,60 & 3,60 & 3,60 & $3,60^{A}$ \\
\hline 30 & 3,60 & 3,60 & 3,60 & 3,60 & $3,60^{A}$ & 3,61 & 3,61 & 3,60 & 3,60 & $3,61^{A}$ \\
\hline 60 & 3,61 & 3,60 & 3,60 & 3,61 & $3,61^{A}$ & 3,61 & 3,61 & 3,60 & 3,60 & $3,61^{A}$ \\
\hline 90 & 3,60 & 3,61 & 3,61 & 3,61 & $3,61^{A}$ & 3,61 & 3,61 & 3,60 & 3,60 & $3,61^{A}$ \\
\hline 120 & 3,61 & 3,61 & 3,61 & 3,60 & $3,61^{\mathrm{A}}$ & 3,60 & 3,61 & 3,61 & 3,60 & $3,61^{A}$ \\
\hline 150 & 3,60 & 3,60 & 3,60 & 3,61 & $3,60^{A}$ & 3,62 & 3,60 & 3,60 & 3,61 & $3,61^{\mathrm{A}}$ \\
\hline 180 & 3,61 & 3,60 & 3,61 & 3,61 & $3,61^{\mathrm{A}}$ & 3,60 & 3,60 & 3,61 & 3,61 & $3,61^{\mathrm{A}}$ \\
\hline Médias & $3,60^{A}$ & $3,60^{A}$ & $3,60^{A}$ & $3,61^{A}$ & & $3,61^{A}$ & $3,61^{A}$ & $3,60^{A}$ & $3,60^{A}$ & \\
\hline $\mathrm{F}$ (Trat) & \multicolumn{4}{|c|}{$0,35 \mathrm{n} . \mathrm{s}$} & \multicolumn{6}{|c|}{ 0,96n.s. } \\
\hline F(Tempo) & \multicolumn{4}{|c|}{$2,50 \mathrm{n} . \mathrm{s}$} & \multicolumn{6}{|c|}{$0,55 \mathrm{n} . \mathrm{s}$} \\
\hline
\end{tabular}

$\mathrm{T} 1, \mathrm{~T} 2, \mathrm{~T} 3 \mathrm{e} \mathrm{T} 4=$ tratamentos

n.s. = não significativo

Médias com a mesma letra não diferem entre si ao nível de 5\% de significância

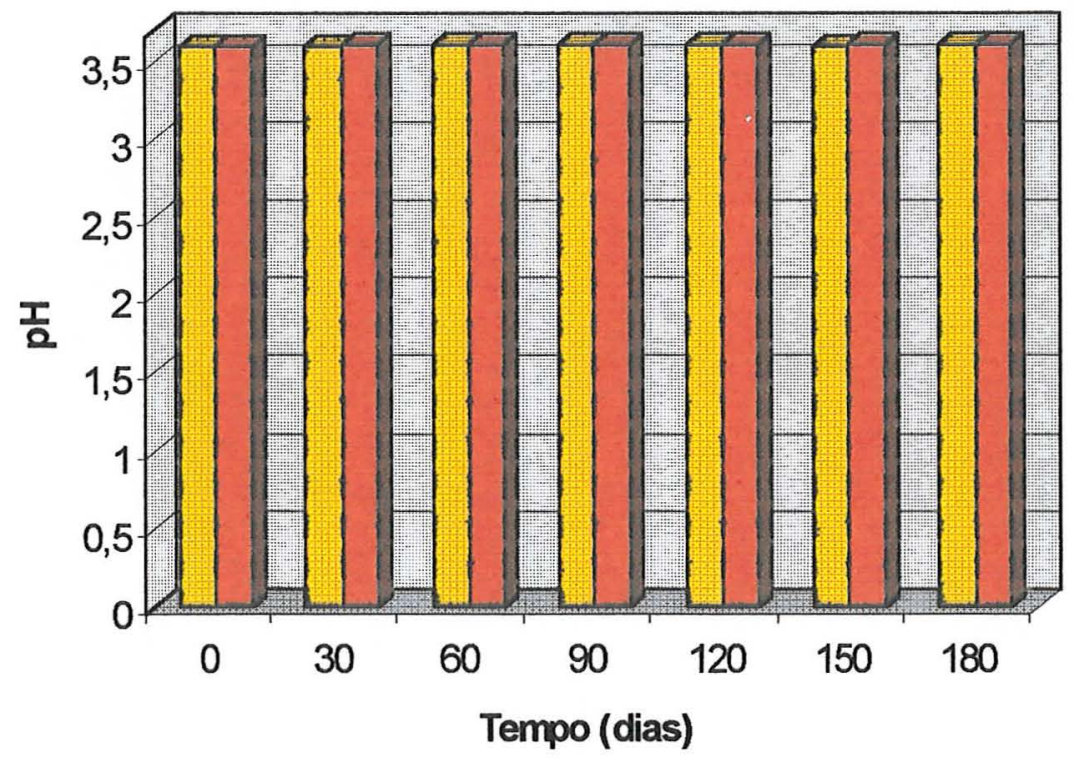

$\square$ Aurora-1

aDourado-2

Figura 25 - Variação do $\mathrm{pH}$ dos néctares light, em função do tempo de armazenamento 
Souza Filho et al. (1992) que não detectaram mudanças de $\mathrm{pH}$ no processamento de xarope de cajú pasteurizado, durante o armazenamento.

Chitarra \& Chitarra (1990) explicam que os valores de $\mathrm{pH}$ podem se manter estáveis apesar dos valores de acidez total titulável diminuírem em função do tempo de armazenamento dos néctares, mesmo que estes parâmetros estejam relacionados entre si. Este fato foi também observado nos néctares comuns.

Na Tabela 18 e Figura 26 são apresentados os valores médios de sólidos solúveis totais ( $\left.{ }^{\circ} \mathrm{Brix}\right)$ dos néctares de ambos cultivares e nem para os tratamentos e nem para o período de armazenamento foram observadas variações estatísticas significativas. Costell et al. (1996) analisando néctar light de pêssego, formulado com edulcorante aspartame e $60 \%$ de fruta, encontraram valores de solidos solúveis em torno de $7,2^{\circ} \mathrm{Brix}$.

Essa estabilidade entre os tratamentos é devido aos néctares estudados terem sido preparados para terem Brix de equilíbrio em torno de $12^{\circ}$. Resultados semelhantes foram obtidos por Novaes (1997) em néctares de morango dietéticos. Já El-Zoghbi \& Siliha (1992) observaram uma acentuada queda nos valores de sólidos solúveis totais em néctares dietéticos light de damasco.

\subsection{3 - Análise sensorial}

Os resultados da avaliação sensorial dos néctares light estão apresentados nas Tabelas 19 e 20 . A Tabela 19 , mostra que quanto a cor a menor média para os dois cultivares foi dada ao tratamento 4 que recebeu adição de ácido ascórbico no processamento. 
Tabela 18 - Valores médios de sólidos solúveis ( ${ }^{\circ}$ Brix) dos néctares light, em função do tempo de armazenamento

Cultivares

Aurora-1

Dourado-2

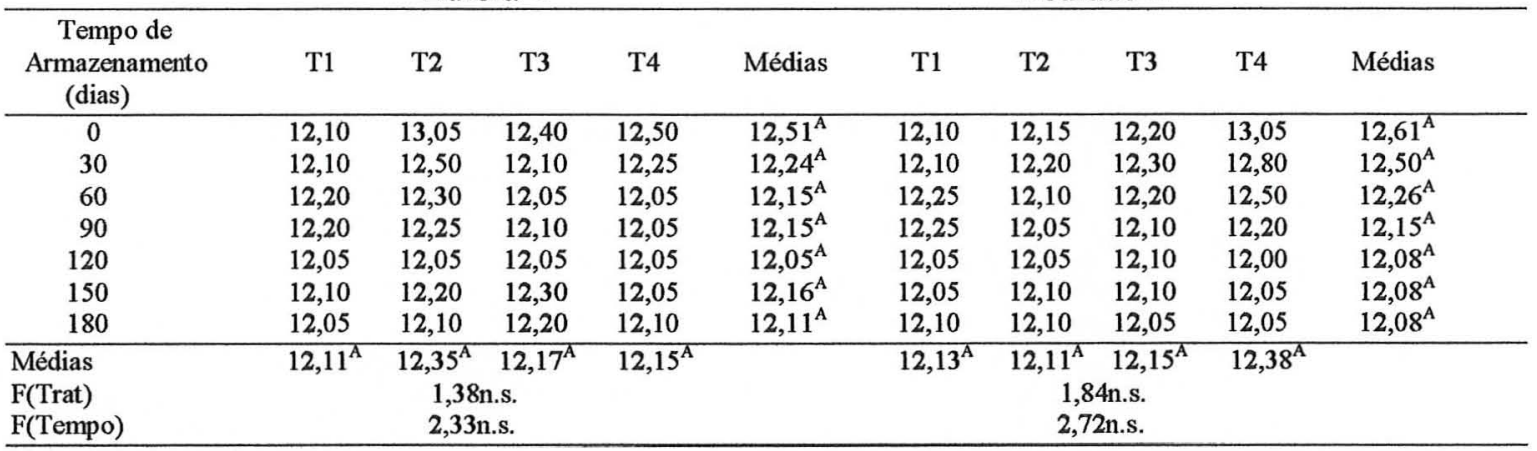

$\mathrm{T} 1, \mathrm{~T} 2, \mathrm{~T} 3$ e $\mathrm{T} 4$ = tratamentos

n.s. = não signifícativo

Médias com mesma letra não diferem entre si ao nível de 5\% de significância
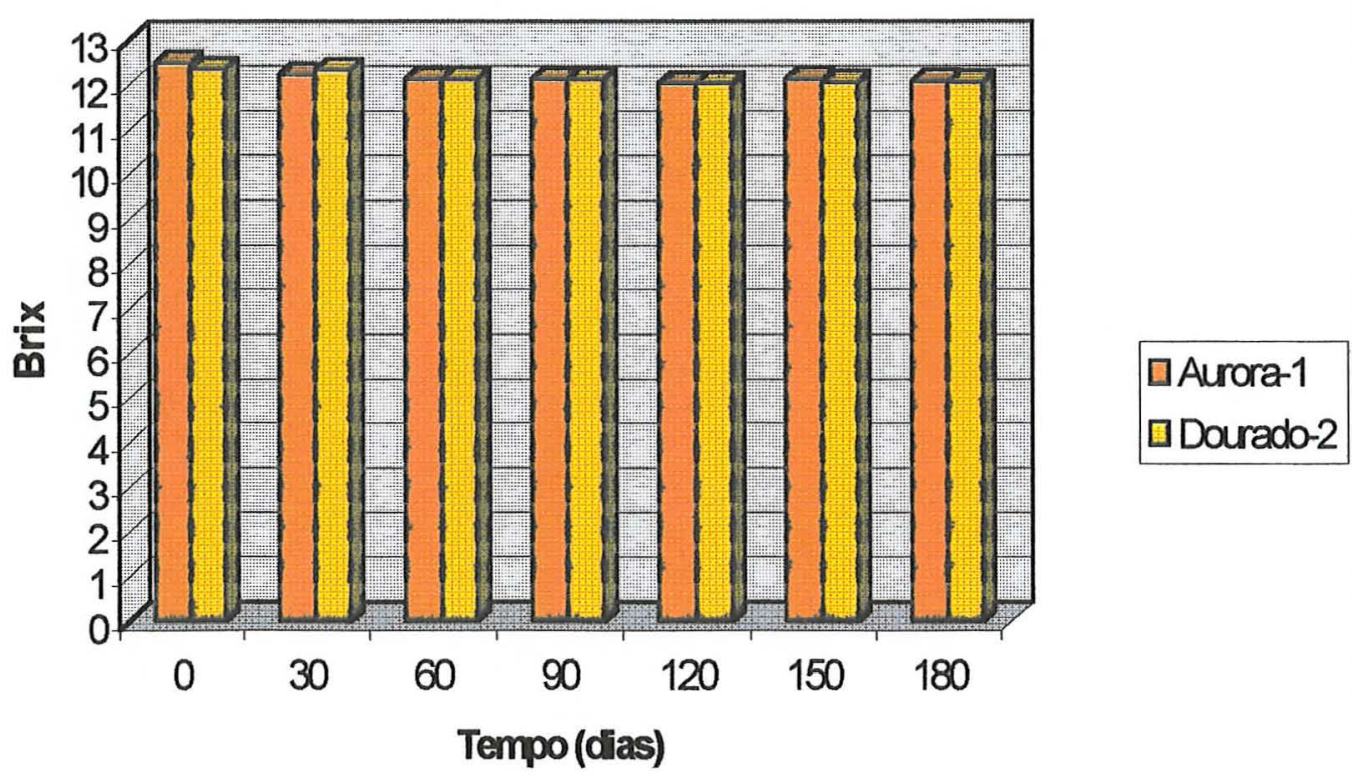

Figura 26 - Variação do teor de sólidos solúveis totais dos néctares light, em função do tempo de armazenamento 
Tabela 19 - Valores médios da análise sensorial dos néctares light, em função dos tratamentos

\section{Cultivares}

Aurora-1

Dourado-2

\begin{tabular}{ccccccc}
\hline & & & & & \\
TRATAMENTOS & COR & CONSIST. & SABOR & COR & CONSIST. & SABOR \\
\hline T1 & $6,38^{\mathrm{B}}$ & $7,13^{\mathrm{A}}$ & $6.60^{\mathrm{A}}$ & $6.59^{\mathrm{B}}$ & $7,25^{\mathrm{A}}$ & $7,09^{\mathrm{A}}$ \\
T2 & $8,34^{\mathrm{A}}$ & $7,25^{\mathrm{A}}$ & $7.29^{\mathrm{A}}$ & $8.50^{\mathrm{A}}$ & $7,29^{\mathrm{A}}$ & $7,63^{\mathrm{A}}$ \\
T3 & $6,71^{\mathrm{B}}$ & $7,50^{\mathrm{A}}$ & $6,80^{\mathrm{A}}$ & $6.79^{\mathrm{B}}$ & $7,59^{\mathrm{A}}$ & $7,30^{\mathrm{A}}$ \\
T4 & $6,13^{\mathrm{B}}$ & $6,50^{\mathrm{A}}$ & $5.92^{\mathrm{B}}$ & $6.21^{\mathrm{B}}$ & $6,75^{\mathrm{A}}$ & $6,46^{\mathrm{B}}$ \\
\hline F(Trat) & $10,74^{*}$ & 6,21 ln.s. & $7,46^{*}$ & $11,17^{*}$ & 5,24 n.s. & $5,10^{*}$ \\
F(Cultivares) & $84,47^{*}$ & $31,02^{*}$ & $20,70^{*}$ & $84.47^{*}$ & $31,02^{*}$ & $20,70^{*}$ \\
\hline
\end{tabular}

* = significativo ao nível de $5 \%$

n.s. = não significativo

Médias com a mesma letra, ao longo de cada coluna, não diferem entre si ao nível de $5 \%$ de significância

Tabela 20 - Valores médios da análise sensorial dos néctares light, em função do tempo de armazenamento

\section{Cultivares}

Aurora-1

Dourado-2

\begin{tabular}{|c|c|c|c|c|c|c|}
\hline TEMPO (dias) & COR & CONSIST. & SABOR & COR & CONSIST. & SABOR \\
\hline 30 & $7,88^{A}$ & $7,79^{A}$ & $7.66^{A}$ & $7.94^{A}$ & $7,63^{\AA}$ & $7,25^{A}$ \\
\hline 60 & $6,66^{A}$ & $7,38^{A}$ & $7,06^{\AA}$ & $7.04^{A}$ & $7,25^{\mathrm{AB}}$ & $6,79^{A}$ \\
\hline 90 & $6.31^{\mathrm{A}}$ & $6,47^{\mathrm{B}}$ & $6.63^{A}$ & $6.75^{\mathrm{A}}$ & $6.44^{\mathrm{B}}$ & $6,07^{\mathrm{A}}$ \\
\hline F(Tempo) & $1.32 \mathrm{n} . \mathrm{s}$. & $6,33^{*}$ & $2.64 n .5$. & $2.63 \mathrm{n} . \mathrm{s}$ & $3,93^{*}$ & $2,38 \mathrm{n} . \mathrm{s}$ \\
\hline
\end{tabular}

$*$ = significativo ao nível de $5 \%$

n.s. = não significativo

Médias com a mesma letra, no sentido vertical, não diferem entre si ao nível de $5 \%$ de significância

Em estudo com néctar dietético de morango, Novaes (1997), detectou também que as menores médias do atributo cor, foram dadas ao tratamento que recebeu ácido ascórbico na formulação. O escurecimento dos néctares armazenados a temperatura ambiente foi também notado por Salomon et al. (1977a), porém mesmo havendo alteração, não foi afetada a preferência dos 
degustadores. Nesse mesmo trabalho observou-se a diminuição da viscosidade dos néctares, após armazenamento de 6 meses, provavelmente, devido a hidrólise da matéria péctica contida no produto.

Segundo Alves \& Garcia (1993), a oxidação do ácido ascórbico + ácido dehidroascórbico dentre outros produz compostos com radical carbonila, que se polimerizam produzindo pigmentos escuros, os quais são responsáveis pelo escurecimento dos produtos que contêm essa vitamina.

A coloração dos néctares light dos dois cultivares também foi afetada ao longo do armazenamento (Tabela 20), porém não foi observada nenhuma perda significativa de qualidade. Observa-se pela Figura 27 que durante todo o período de armazenamento o cultivar Dourado-2 apresentou néctares com coloração superior aos da Aurora-1.

Quanto à consistência (Tabela 19) o tratamento 4 de ambos cultivares foi o que recebeu as menores médias, enquanto o tratamento 3 apresentou os melhores resultados para esse atributo de qualidade. Isto deve ter ocorrido devido, a adição combinada de sorbato de potássio e ácido cítrico. Segundo Novaes (1997) o ácido cítrico atua como um agente melhorador de consistência para néctar.

A Tabela 19 mostra que a consistência não apresentou variação estatística significativas entre os tratamentos, porém as notas atribuídas a este atributo de qualidade diminuíram com o tempo de armazenamento (Tabela 20). Pilando et al. (1985) também notaram esse fato ao estudar a composição do suco de morango produzido com frutas em vários estágios de maturação. A Figura 28 ilustra que o cultivar Dourado-2 apresentou néctares com melhor consistência que os da Aurora-1. 


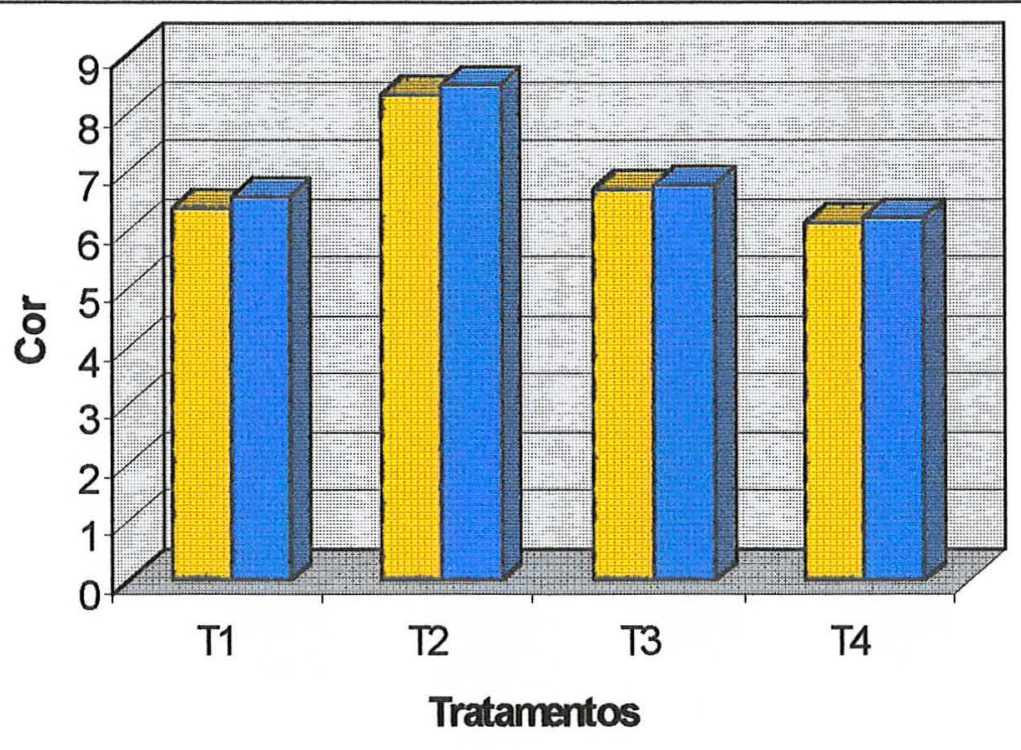

$\square$ Aurora-1

GDourado-2

Figura 27 - Valores médios das notas obtidas na avaliação sensorial, quanto à cor, dos néctares light

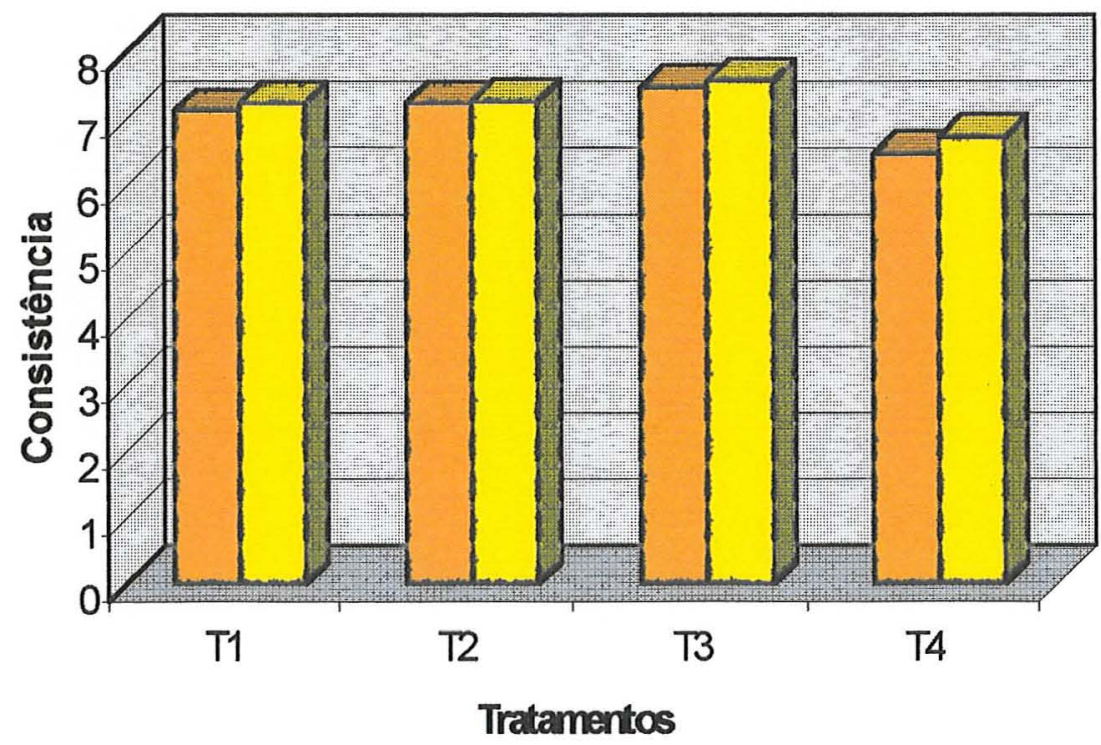

口Aurora-1

aDourado-2

Figura 28 - Valores médios das notas obtidas na avaliação sensorial, quanto à consistência dos néctares light 
Os néctares light dos dois cultivares (Tabela 19 e Figura 29), apresentaram T2 como o melhor tratamento quanto ao sabor. Este tratamento foi armazenado sob refrigeração e por isto manteve o néctar mais estável quanto aquele atributo de qualidade.

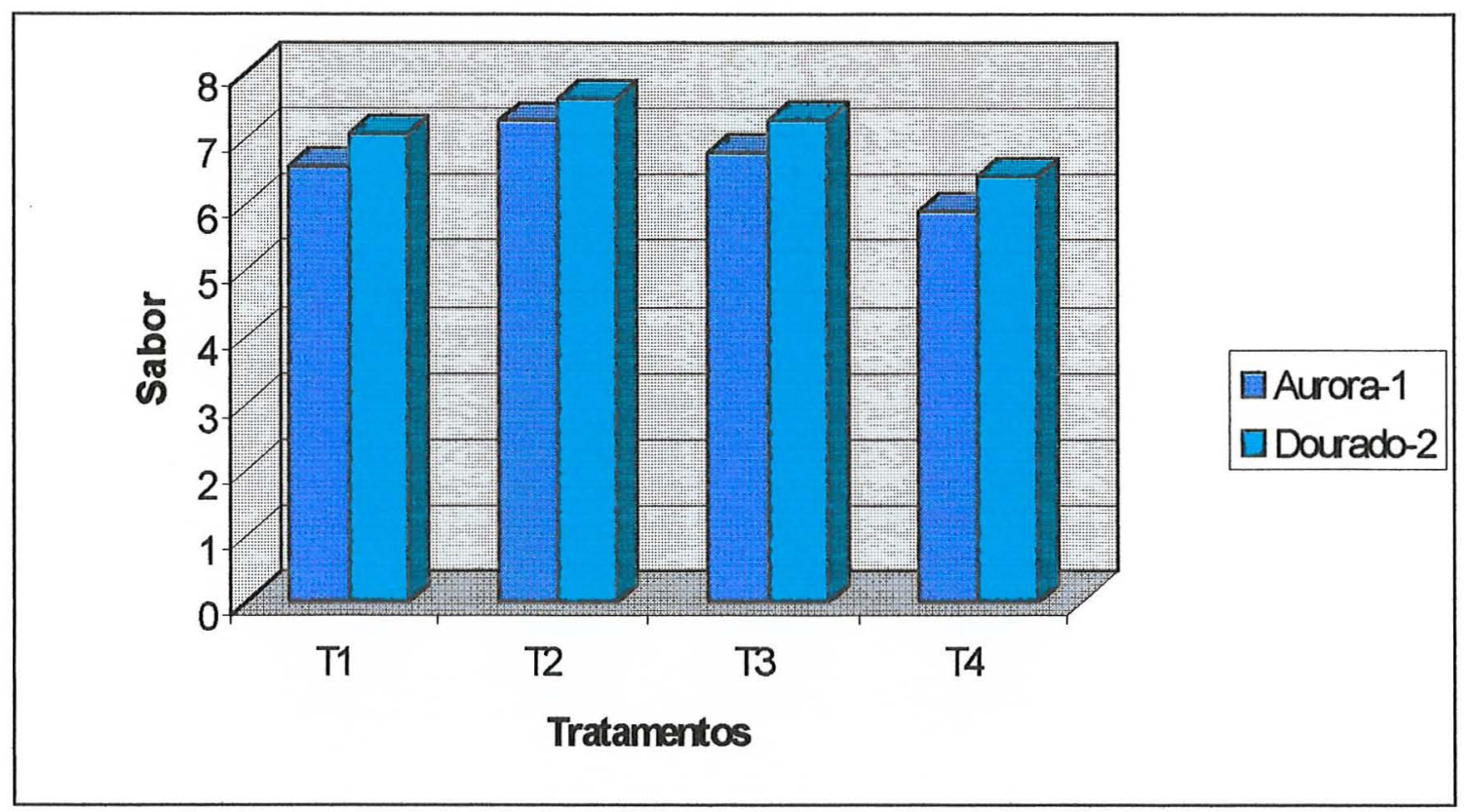

Figura 29 - Valores médios das notas obtidas na avaliação sensorial, quanto ao sabor dos néctares light.

O tratamento 4, que diferiu estatisticamente dos demais tratamentos, recebeu a pior avaliação quanto ao sabor o que deve ter ocorrido devido a adição de ácido ascórbico, conferindo um gosto mais ácido ao produto. Isto mostra que a preferência é maior para produtos de menor acidez.

Pelos resultados obtidos podemos ressaltar a boa interação dos edulcorantes (aspartame + sorbitol) que não apresentou gosto residual não alterando o sabor dos néctares ao longo do período de armazenamento, assegurando a estabilidade e mostrando o excelente potencial de uso para 
esses produtos em néctares light de pêssego. Costell et al. (1996) estudando atributos sensoriais de néctares dietéticos light de pêssego, contendo aspartame, avaliou o produto como mais doce, com maior sabor de pêssego e sem características de sabores artificiais e estranhos.

Conforme mostra a Tabela 20, as médias das notas dadas ao sabor dos néctares dos dois cultivares tendem a diminuir com o tempo de armazenamento, porém mesmo aos 90 dias este atributo foi avaliado de regular para bom, mostrando ainda sabor característico de pêssego, comprovando as boas condições em que se encontravam.

Observando as Tabelas 19 e 20 e a Figura 30, pode-se afirmar que os néctares do cultivar Dourado-2 obteve notas com médias superiores para todos os atributos de qualidade avaliados.

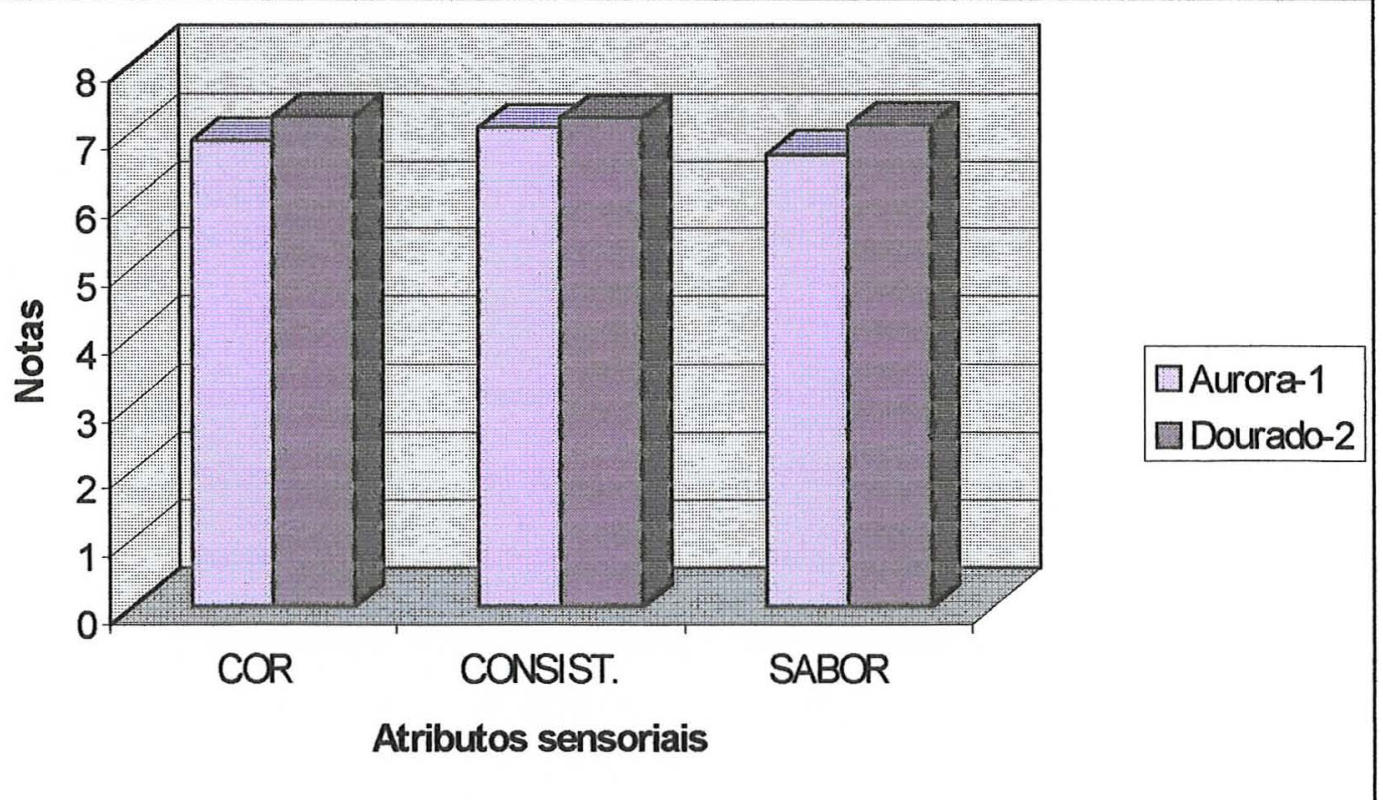

Figura 30 - Valores médios das notas obtidas na avaliação sensorial, quanto aos atributos de qualidade dos néctares light 


\section{CONCLUSÕES}

Com base nos resultados obtidos, as seguintes conclusões podem ser destacadas:

- É possível elaborar néctar e néctar light com os cultivares estudados.

- O néctar e néctar light dos cultivares Aurora-1 e Dourado-2 caracterizaram-se sob os pontos de vista físico-químico e organoléptico como produtos de boa qualidade.

- O néctar e néctar light do cultivar Dourado-2 apresentaram melhor cor, consistência e sabor em relação aos néctares do cultivar Aurora-1.

- A adição de ácido ascórbico não é um tratamento que deve ser recomendado uma vez que prejudica a qualidade sensorial dos néctares, principalmente quanto à cor.

- Mesmo após seis meses de armazenamento, o néctar e néctar light dos dois cultivares que não receberam adição de ácido ascórbico, apresentaram razoáveis teores desta vitamina $(21 \mathrm{mg} / 100 \mathrm{~g})$.

- A adição de ácido ascórbico permitiu obter um teor final mais elevado que os demais tratamentos, em torno de $50 \mathrm{mg} / 100 \mathrm{~g}$.

- As perdas dos teores de ácido ascórbico do néctar e néctar light de ambos cultivares, aumentaram com o período de armazenamento. 
- A adição de ácido cítrico permitiu obter néctar e néctar light de ambos cultivares, estáveis ao longo do período de armazenamento quanto à cor e $\mathrm{pH}$.

- A refrigeração mostrou-se um dos melhores tratamentos, quanto ao sabor e cor, para o néctar e néctar light dos dois cultivares.

- A adição de sorbato de potássio permitiu obter néctares com maior estabilidade, e de melhor sabor.

- A interação dos edulcorantes aspartame e sorbitol foi adequada para o preparo dos néctares, não apresentando gosto residual e não alterando o sabor dos mesmos ao longo do período de armazenamento.

- Após 90 dias de armazenamento, o néctar e néctar light ainda apresentaram sabor característico de pêssego.

- O cultivar Dourado-2 foi o que apresentou características químicas e organolépticas mais adequadas para o preparo do néctar e néctar light. 


\section{REFERÊNCIAS BIBLIOGRÁFICAS}

ÁCIDO sórbico. Engarrafador Moderno, v. 4, n. 2, p.48-52, mar., 1979.

AGGARWAL, P.; BAJAJ, M.; MINHAS, K. S.; SIDHU, J. S. Comparative studies on the suitability of Shane-Punjab and Flordasun peach varieties for processing. Journal of Plant Science Research, v.1/4, n.8, p.77-80, 1992.

AGUIAR, E.; MORAES, I. R.; LIMA. M. F. Estudos sobre o esteviosídeo. Boletim da Sociedade Brasileira de Ciência e Tecnologia de Alimentos, v.21, n.2, p.121-123, 1987.

ALBREGTS, E. E.; HOWARD, C. M. Elemental composition of fresh strawberry fruit. Journal of the American Society for Horticultural Science, v. 103, n.3, p.293-296, 1978.

ALMEIDA, P. G. de. Edulcorantes a opção diet. Engarrafador Moderno, v.7, n.46, p.57-63, jul./ago. 1996a. 
ALMEIDA, P. G. de. O uso de acidulantes e conservantes em bebidas. Engarrafador Moderno, v.7, n.47, p.41-48, set./out. 1996b.

ALVES, R. M. V.; GARCIA, E. E. C. Embalagem para sucos de frutas. Coletânea do Instituto de Tecnologia de Alimentos, v.23, n.2, p. 105122, jul./dez. 1993.

AMOEDO, C. Menos calorias - mais sabor. Saúde, n.166, p.24-36, jul. 1997.

ANDRADE, M. O. de; CAMARGO, R. de. Tecnologia de alimentos e nutrição. In: CAMARGO, R.; FONSECA, H.; PRADO FILHO, L. G. et al. Tecnologia dos produtos agropecuários: alimentos. São Paulo: Nobel, 1989. cap.2, p. 9-32.

ANGELUCCI, E. Edulcorantes. Boletim Informativo do Instituto de Tecnologia de Alimentos, v.3, n.3, p.8-10, set./dez., 1989a.

ANGELUCCI, E. Edulcorantes e adoçantes em alimentos. Boletim Informativo do Instituto de Tecnologia de Alimentos, v. 11, p. 14-15, abr/jun. 1989b.

ANGELUCCI, E. Legislação brasileira sobre aditivos para alimentos. Boletim Informativo do Instituto de Tecnologia de Alimentos, v.3, n.1, 85p. jan./abr., 1989c. 
ANJOS, C. A. R.; ANJOS, V. D. A. Características do alumínio utilizado em embalagens de alimentos. Boletim da Sociedade Brasileira de Ciência e Tecnologia de Alimentos, v.19, n.2, p.85-94, 1985.

ANTUNES, A. J.; CANHOS, V. P. Aditivos em alimentos. São Paulo : Secretaria da Indústria, Comércio, Ciência e Tecnologia, 1982. 178p.

ARADHITA, B.; GUPTA, O. P.; GHAWAN, S. S. Evaluation of guava (Psidium guajava) hybrids for making nectar. Haryana Journal of Horticultural Science, n.24, v.2, p.102-109, 1995.

ARAÚJO, J. M. A. Conservadores químicos em alimentos. Boletim da Sociedade Brasileira de Ciência e Tecnologia de Alimentos, v.24, n.3/4, p.192-210, jul./dez. 1990.

AREAAS, F. A era diet. Alimentos e Tecnologia, v.7, n.38, p.34-35, 1991.

ASKAR, A.; EL-SAMAHY, S.; IBRAHIM, S. et al. Reduction of heavy metal content and improving quality of canned mango nectar. Fruit Processing, v.3, n. 3, p. 84-92, 1993.

ASKAR, A.; GHONAIM, S. M.; ABDEL, F. M. G. et. al. Quality assurance of peach pulp and nectar. Fruit Processing, v.6, n.4, p.151-155, 1996.

ASPARTAME: amino acid based sweetener. Tokio: Ajinomoto, s.d. (a) 16p. 
ASPARTAME: o edulcorante à base de aminoácidos. São Paulo: Ajinomoto Interamericana, s.d. (b) n. p.

ASPARTAME: sugestões de formulações. São Paulo: Ajinomoto Interamericana, s.d. (c) $10 \mathrm{p}$.

ASSOCIAÇÃO BRASILEIRA DA INDÚSTRIA DE ALIMENTOS DIETÉTICOS. Guia brasileiro de alimentos e bebidas dietéticas. São Paulo, 1992. 154p.

ASSOCIATION OF OFFICIAL ANALYTICAL CHEMISTS. Oficial methods of analysis. 15.ed. Washington, 1985. 1094p.

BANZATTO, D. A.; KRONKA, S. N. Experimentação agrícola. 3.ed. Jaboticabal: FUNEP, 1995. 247p.

BARAMANRAY, A.; GUPTA, O. P.; DHAWAN, S. S. Evaluation of guava (Psidium guajava) hybrids for making nectar. Haryana Journal of Horticultural Sciences, v.24, n. 2, p. 102-109. Abr./Jun. 1995.

BARBOSA, W.; DALl'ORTO, F. A. C.; OJIMA, M. Comportamento vegetativo e reprodutivo do pêssego Tropical : cultivar bem precoce no Planalto Paulista. Boletim Científico IAC, n. 21, p. 2 - 22, 1990. 
BARBOSA, W.; OJIMA, M.; DALL'ORTO, F. A. C. et al. Melhoramento do pessegueiro para regiões de clima subtropical-temperado: realizações do Instituto Agronômico no período de 1950 a 1990. Campinas: IAC, 1997. 22p. (IAC. Documentos, 52).

BELO, V. Diet e light : a discussão continua. CRN Notícias. n.41, p.4-5, jul./set. 1995.

BERBARI, S. A. G.; NOGUEIRA, J. N.; PASSOS, F. Determinações das características químicas e organolépticas de novas variedades de morango para congelamento. Boletim da Sociedade Brasileira de Ciência e Tecnologia de Alimentos, v. 28, n. 1, p. 18-24, jan./jun. 1994.

BERNHARDT, L. W. Comparação entre os ácidos cítricos e lácticos na confecção de bananada e goiabada. Coletânea do Instituto de Tecnologia de Alimentos, v.5, n.12, p.107-116, 1973 / 74.

BLEINTOTH, E. W.; SALOMÓN, E. A. G.; KATO, K. et al. Formulações de néctares de frutas tropicais. Boletim do Instituto de Tecnologia de Alimentos, v.5, n. 50, p. 103-121, mar./abr., 1977.

BOBBIO, F. O; BOBBIO, P. A. Introdução à química de alimentos. 2.ed. São Paulo: Varela, 1989. 223p.

BOURNE, M. C. Effect of temperature on firmness of raw fruits and vegetables. Journal of Food Science, v.47, n.2, p.440-444, 1982. 
BRASIL. Ministério da Agricultura. Complementação de padrões de identidade e qualidade para suco, refresco, néctar e refrigerante de fruta. Brasília, 1974. 33p.

BRASIL. Leis, decretos, etc. Portaria n. 41 de 12 de Maio de 1995. Diário Oficial [ da República Federativa do Brasil ], Brasília, p.6887-8, 15 de Maio. 1995. Seção 1.

BRASIL. Leis, decretos, etc. Conselho Nacional da Saúde. Resolução $n^{\circ} 4$ de 24 de novembro de 1988. Diário Oficial, Brasília, Seção I, 19/12/88a. P.24.716-24.723.

BRASIL. Leis, decretos, etc. Resolução $n^{\circ} 04 / 88$ do Decreto Lei ${ }^{\circ}$ 55.871/65. In: ASSOCIAÇÃO BRASILEIRA DAS INDÚSTRIAS DE ALIMENTOS. Compêndio da legislação de alimentos. São Paulo: ABIA, 1988b. ver. 4, v. 1, p. 3.50.

BREKKE, J. E.; CAVALETTO, C. G.; NAKAYAMA, T. O. M. Effects of storange temperature and container lining on some quality attributes of papaya nectar. Journal of Agricultural and Food Chemistry, v.24, n 2, p.341-343, 1976.

CABALLERO, B.; MAHON, B. E.; ROHR, F. Y.; et al. Plasma amino acid levels after single-dose aspartame consumption in phenilketonuria, mild hyperphenylalaninemia, and heterozygous state for phenylketonuria. Journal of Pediatrics. v. 109, n. 6, p. 668-671, 1986. 
CARRARO, A. F.; CUNHA, M. M. Manual de exportações de frutas. Brasília: Instituto Interamericano de Cooperação para a Agricultura, 1994. 252p.

CARVALHO, P. R. N. Enriquecimento de alimentos: o uso de vitaminas e sais minerais para aumentar o valor nutritivo dos alimentos. Engarrafador Moderno, v.6, n.39, p.54-59, maio/jun. 1995.

CHEFTEL, J. C.; CHEFTEL, H.; BESANÇON, P. Introduccion a la bioquimica y tecnologia de los alimentos. Zaragoza: Acribia, 1987. $404 p$.

CHITARRA, M. I. F.; CHITARRA, A. B. Pós-colheita de frutos e hortaliças: fisiologia e manuseio. Lavras: Fundação de Apoio ao Ensino, Pesquisa e Extensão, 1990. 293p.

CID, C.; BELLO; J.; ATIASARÁN, I. Repercusion de diferentes tipos de tratamientos de coccion en el contenido en vitamina $\mathrm{C}$ de las verduras. Alimentaria, v. 27, n. 209, p.1-21, jan/fev. 1990.

CLYDESDALE, F. M. Color as a factor in food choice. Critical Reviews in Food Science and Nutrition, v.33, n.1, p.83-101, 1993.

COSTA, C. M. A. Análise crítica de produtos ditos "Diet" \& "Light". In: REGITANO-d'ARCE, M. A.B. Seminários em Ciência e Tecnologia de Alimentos. Piracicaba: ESALQ, Depto. de Ciência e Tecnologia Agroindustrial, 1995a. p. 1-13. 
COSTA, H. M. da. Os dietéticos e suas propriedades. Nutrição em Pauta, v.3, n.2, p.15, mar./abr. 1995 b.

COSTELL, M. V.; DURÁN, L.; IZQUIERDO, L. Perfil descriptivo de néctares de melocotón. Evaluación de jueces y de atributos com el análisis de Procrustes generalizado. Food Science and Technology International, v. 2, n. 4, p. 219-230. 1996.

CRUESS, W. V. Produtos industriais de frutas e hortaliças. São Paulo : Edgard Blucher, 1973. v.1, 446p.

DAll'ORTO, F. A. C.; OJIMA, M.; RIBEIRO, I. J. A. et. al. Projeto integrado de pesquisa : "frutas de clima temperado"- diagnóstico da situação econômica e cultural, atividades de pesquisa e pontos de estrangulamento. Campinas: ITAL, 1984. 374p.

DAWSON, R. H. Sensory texting guide for panel evaluation of food and beverages. Food Technology, v.8, n. 18, p.25-31, 1964.

DAYRELL, I. Q.; MOURA COSTA, G. C.; BRITO, M. F. Determinação de ácido benzóico em sucos de frutas. Boletim da Sociedade Brasileira de Ciência e Tecnologia de Alimentos, v.26, n.2, p. 67-70, jul./dez. 1992.

DE MARTIN, Z.; TEIXEIRA, C. G.; BLEINROTH, E. W. et al. Processamento de purê e néctar de mamão pasteurizados. Coletânea do Instituto de Tecnologia de Alimentos, v. 4, n.15, p. 155-176. 1971/72. 
DIAZ, M. A.; ORZAEZ, V. M. T.; MATALLANA, G. M. C. Vitamin C in dietetic products, I. juices and nectars. Alimentaria, v. 24, n.180, p.67$70,1987$.

DÍEZ, C.; TORIJA, M. E.; CÁMARA, M. M. Influencia del sistema de envasado en la composicion de nectares de piña. Alimentaria, v.33, n. 261, p. 65-67, abr. 1995.

DWIVEDI, B. K. Sorbitol and manitol. In: NABORS, L. B., GELARDI, R. C. Alternative sweeteners. 2.ed. New York : Marcel Dekker, 1986. p.333-348.

EL ZOGHBI, M.; SILIHA, M. The effects of low - caloric sweeteners on chemical and physical properties of apricot nectar. Fluessiges Obstracts. , n.59, v.2, p.71-73, 1992.

ESKIN, N. A. M. Quality and preservation of fruits. Boca Raton: CRC Press, 1991. 375p.

EVANGELISTA, J. Tecnologia de alimentos. Rio de Janeiro: Atheneu, 1992. $652 \mathrm{p}$.

FERREIRA, V. L. P. Teoria da cor. Campinas: ITAL, 1991. 114p.

FIGUEIREDO, I. Dosagem de gases no espaço livre em alimentos enlatados. Boletim do Centro Tropical de Pesquisas e Tecnologia de Alimentos, v. 3, n.14, p.31-36, 1968. 
FIGUEIREDO, I. B.; UZELAC, M. Aromas em alimentos. Campinas : ITAL, 1976. p. 69 (ITAL. Instruções Técnicas, 9).

FNP CONSULTORIA \& COMÉRCIO. Agrianual 1998: anuário da agricultura brasileira. São Paulo, 1998. p.333-339: Pêssego.

FONSECA, H.; NOGUEIRA, J. N. Processamento e conservação de produtos de origem vegetal - frutas. In : CAMARGO, R.; FONSECA, H.; PRADO FILHO, L. G. et al. Tecnologia dos produtos agropecuários: alimentos. São Paulo : Nobel, 1989. cap.7, p. 113-124.

FRANCO, G. Tabela de composição química dos alimentos. 9. ed. São Paulo: Atheneu, 1992. 230p.

FRANCO, J. A. M.; PENTEADO, S. R.; JUNQUEIRA, W. R. Cultura do pessegueiro. Campinas: IAC, 1983. 207p. (IAC. Comunicado Técnico, $50)$.

GAVA, A. J. Princípios de tecnologia de alimentos. São Paulo: Nobel, 1978. 284p.

GAVA, A. J. Controvérsia sobre aditivos em alimentos. Alimentos e Tecnologia, v.13, n. 4, p.28-30, jan./fev. 1987.

GHERARDI, S.; AGLIO, G.; CARPI, G. Plastics containers for packaging fruit juices and nectars. Industria Conserve, v.3, n.47, p.189-191, 1972. 
GIRARDOT, N. F.; PERYAM, D. R.; SHARPIRO, L. Selection of sensory testing panels. Food Technology, v.4, n.6, p.140-143, 1952.

GOFUR, M. A.; SHAFIQUE, M. Z; HELALI, O. H. et. al. Studies on the formulation and ripe mango nectar. Bangladesh Journal of Scientific and Industrial Research, v.29, n.3, p.151-162, 1994.

GOLDONI, J. S.; CEREDA, M. P.; CACLIARI, A. M.; Variação do teor de ácido ascórbico em suco integral durante armazenamento pelo frio. I. Morango (Fragaria $s p$ ). Associação Brasileira das Indústrias da Alimentação, n. 55, p. 24-30, ago., 1981.

GOMES, F. P. Curso de estatística experimental. 10. ed. Piracicaba: Nobel, 1982.430p.

GRAUMLICH, T. R.; MARCY, J. E.; ADAMS, J. P. Aaaeptically package orange juice and concentrate: a review of the influence of processing and packaging conditions on quality. Journal of Agriculture and Food Chemistry, v.34, n. 3, p. 402-405, 1986.

HERNANDEZ, I.; RIVERA, O. J. M.; BUESO, C. E. Vitamin C enrichment of banana nectar. Journal of Agriculture of the University of Puerto Rico, v.2, n.60, p.250-251, 1976.

HOFFMANN, F. Vitamin compendium. Basel : La Roche, 1976. 152p. 
HUDSON, M. A.; HOLGATE, M. E.; GREGORY, M. E. et al. Home fronzen strawberries. II. Influence of additives in syrup on sensory assessments and texture measurements. Journal of Food Technology, v. 10, n.6, p. $689-698,1975$.

IRANZO, J. R.; TORÁN, M. J. P. Relación entre los grados Brix de los zumos cítricos y sus componentes solubles. Revista de Agroquímica y Tecnologia de Alimentos, v. 17, n. 4, p. 435-443, dic. 1977.

JOHNSON, L. E. Food technology of the antioxand nutrients. Critical Reviews in Food Science and Nutrition, v.35, n. 1/2, p.149-159, 1995.

KANESIRO, M. A. B.; FALEIROS, R. R. S.; SARTORI, J. L. et al. Efeitos de níveis de $\mathrm{N}$ e $\mathrm{P}$ sobre algumas características químicas de frutos do tomateiro colhidos em diferentes estágios de maturação. Científica, v.10, n. 2, p.233, 1982.

KATO, K.; MARTIN, Z. J. Polpa de goiaba. In : MEDINA, J. C.; GARCIA, J. L. M.; KATO,K. et al. Frutas tropicais: goiaba. Campinas : ITAL, 1978. p.61-79. (ITAL. Série Frutas Tropicais, 6).

KHURDIYA, D. S. Composition and quality of nectar prepared from blended pulps of Amrapali and Totapuri mangoes. Journal of Food Science and Technology, v.2, n.30, p.139-140, 1993. 
LEITÃO, M.; DELAZARI, I.; UBOLDI EIROA, M. N. et al. Avaliação de sucos, refrigerantes, refrescos, néctares e xaropes em face dos padrões microbiológicos brasileiros. Boletim do Instituto de Tecnologia de Alimentos, v.10, n.49, p.75-91, jan./fev. 1977.

LEME JÚNIOR, J. Contribuição ao estudo da geleificação de frutas e do equilíbrio do gel péctico. Piracicaba, 1968. 97p. Dissertação (Mestrado)Escola Superior de Agricultura "Luiz de Queiroz", Universidade de São Paulo.

LOPEZ, A. A. Complete course in canning. 10.ed. Baltimore: The Canning Trade, 1975. 755p.

LOURENÇO, E. J. Aroma em função da adição de ácido ascórbico. In : FIGUEIREDO, I. B.; UZELAC, M. Aromas em alimentos. Campinas : ITAL, 1976. p. 30-58 (ITAL. Instruções Técnicas , 9)

LUH, B. S. Nectars, pulpy juice blends. In : TRESSEL, D. K.; JOSLYN, M. A. Fruit and vegetable juice processing technology. 2 ed. Westport : AVI Publ., 1971. p.346-396.

MAHADEVIAH, M.; GOWRAMMA, R. V.; EIPESON, W. E. et al. Internal corrosion of enplate container in canned mango (Mangidera indica) L. nectar. Journal of Food Science and Agriculture, v.26, n.6, p.821-833, 1975. 
MANAK, B. Specification for mango nectar. New York: Academic Press, 1977. 324p.

MARTIN, S. L. Selection na training of sensory judges. Food Technology, v.27, n.11, p.22-26, 1973.

MARTIN, Z. J. Industrialização da goiaba. Boletim do Instituto de Tecnologia de Alimentos, v.12, n. 32, p.37-54, 1969.

MARTIN, Z. de; SGARBIERI, V. C.; MENEZES, T. B. et al. Produção de purê de banana acidificado e néctar de banana. Coletânea do Instituto de Tecnologia de Alimentos, v. 1, n.11, p. 273-298, 1965/ 66.

MENEZES, S. A. Os naturais do verão. Alimentos e Tecnologia, v.3, n.21, p. 58-59, fev./mar.1988.

MENEZES, S.; VIEGAS, S. Dietéticos em alta. Alimentos e Tecnologia, v.6, n.32, p.22-25, fev./mar. 1990.

MURADIAN, L. B. A.; PENTEADO, M. V. C. Edulcorantes em alimentos uma revisão. Boletim da Sociedade Brasileira de Ciência e Tecnologia de Alimentos, v.24, n.1/2, p.1-11, jan./jun. 1990.

NABORS, L. O.; GELARDI, R. C. Alternative sweeteners. New York : Marcel Dekker, 1986. 461p. 
NAZÁRIO, G. Aditivos: pior sem eles. Alimentos e Tecnologia. v.3, n. 18, p.31-32, fev./mar. 1988 .

NOGUEIRA, J. N. Tecnologia de produtos de frutas. Piracicaba: ESALQ; SEBRAE, 1994. 57p. (Cursos Agrozootécnicos).

NOVAES, L. C. C. Avaliação da qualidade dos néctares comum e dietético de morango das variedades Guarani e Oso Grande. Piracicaba, 1997. 119p. Dissertação (Mestrado). - Escola Superior de Agricultura "Luiz de Queiroz", Universidade de São Paulo.

OJIMA, M.; DALL'ORTO, F. A. C.; BARBOSA, W. et. al. Pêssego "Aurora"(IAC 680 - 179) . Boletim Técnico IAC, n. 81. p.5-13, jun., 1987.

OJIMA, M.; DALL'ORTO, F. A. C.; BARBOSA, W. et al. 'Dourado-1'e 'Dourado-2': novos cultivares de pêssego amarelo para mesa. Bragantia, v.44, n.1, p. 451-455, 1985.

OLIVA, P. B.; MENEZES, H. C.; FERREIRA, V. L. P. Estudo da estabilidade do néctar de acerola. Sociedade Brasileira de Ciência e Tecnologia de Alimentos, v. 16, n. 3, p. 228-232, out./dez. 1996.

PARMAN, G. K.; SALINARD, G. J. Las vitaminas como ingredientes en la elaboración de alimentos. Basel: Roche Produtos Químicos e Farmaceuticos, 1967. 270p. 
PASCHOALINO, J. E. Congelamento de hortaliças. In : PASCHOALINO, J. E. Processamento de hortaliças. Campinas : ITAL, 1989. p.2-69.

PASSOS, F. A. Caracterização de clones nacionais e introduzidos de morangueiro (Fragaria $X$ ananassa Duch), visando o uso imediato na horticultura e o melhoramento genético. Piracicaba, 1982. 116p. Dissertação (Mestrado) - Escola Superior de Agricultura "Luiz de Queiroz", Universidade de São Paulo.

PAVANELlo, J. F. O uso de aditivos em alimentos. Alimentos e Bebidas, v.7, n.3, p.22-24, 1990.

PAYUMO, E. M.; PILAC, L. M.; MANIQUIS, P. L. A study of colour changes in stored papaya nectar. Philippine Journal of Science, v.97, n.2, p.127-138, 1968.

PENTEADO, S. R. Pêssego (Prunus persica Batsch var. platycarpa). Manual técnico das culturas. 2.ed. Campinas: CATI, 1997. v.3, p. 301305. (Manual, 8).

PILANDO, L. S.; WROLSTAD, R. E.; HEATHERBELL, D. A. Influence of fruit composition, maturity and mold contamination on the color and appearance of strawberry wine. Journal of Food Science, v. 50, n. 4, p. 1121-1125, 1985. / Resumo n.143 em Food Science Technology Abstracts, v. 17, n. 12, p. 91, 1985/ 
PRADO, M. E. T. Vida de prateleira e perda de vitamina $\mathrm{C}$ durante $\mathrm{o}$ armazenamento de um alimento de umidade intermediária obtido da mistura suco-polpa de manga (Mangifera indica L.) - desenvolvimento de modelos matemáticos. Lavras, 1994, 76p. Dissertação (M. S.)- Escola Superior de Agricultura de Lavras.

PREGNOLATTO, W.; PREGNOLATTO, N. P. Normas para análises químicas do Instituto Adolfo Lutz. 3. ed. São Paulo: Instituto Adolfo Lutz, 1985. v.1, 533p.

RAMANA, K. V. R.; RAMASWAMY, H. S.; ARAVINDA, P. B. et al. Freezing preservation ot Totapuri mango pulp. Journal of Food Science and Technology, v.21, n.5, p. 282-285, 1984.

RANGANNA, S. Manual of analysis of fruit and vegetable products. New Delhi : McGraw Hill, 1977. 634p.

REICHCIGL, J. R. M. Handbook of nutritive value of processed food. Boca Raton : CRC Press, 1982-1984. 2v. (CRC Series in Nutrition and Food).

RICHARDS, N. S. P. S. Avaliação da qualidade das variedades Chander e Reiko para a obtenção de morango em calda. Piracicaba, 1996. 90p. Dissertação (Mestrado) - Escola Superior de Agricultura "Luiz de Queiroz”, Universidade de São Paulo. 
ROCHA, I. C. Suco de acerola: efeitos da temperatura de pasteurização e armazenamento. Recife, 1988. 62p. Dissertação (Mestrado). Universidade Federal de Pernambuco.

RODRIGUES, C. Diet e light. Alimentos e Tecnologia, v. 9, n. 58, p. 5558, fev./mar. 1995.

RODRIGUEZ, A. J.; GEORGE, L. M. I. Evalution of papaya nectar prepared from unpeeled papaya puree. Journal of Agriculture of the University of Puerto Rico, v.56, n.1, p.79-80, 1972.

SÃO PAULO. (Estado) Leis, Decretos, etc. Normas Técnicas Especiais Relativas a Alimentos e Bebidas . Decreto $\mathrm{n}^{\circ}$ 12.486, de 20/10/1978 NTA 22 - Néctar de Frutas.

SALOMÓN, E. A.; KATO, K.; MARTIN, Z. J. et. al. Blending of papaya / passion fruit nectar. Boletim do Instituto de Tecnologia de Alimentos, n.51, p.165-179, 1977a.

SALOMÓN, E. A. G.; MARTIN, Z. J. de; KATO, K. et. al. Formulação de néctares de frutas tropicais. Boletim do Instituto de Tecnologia de Alimentos, v.7, n.50, p.103-121, mar/abr., 1977 b.

SANTIAGO, M. M. D.; CAMARGO, M. L. B.; DONADELlI, A. Estimativas dos preços recebidos pelos fruticultores no Estado de São Paulo, 1990-96. Informações Econômicas, v.26, n.6, p.91-99, jun., 1996. 
SIVIERI, K. Avaliação da qualidade de geléias de morango comum e dietética das variedades guarani e osso grande. Piracicaba, 1997. 124p. Dissertação (Mestrado) - Escola Superior de Agricultura "Luiz de Queiroz", Universidade de São Paulo.

SOLER, M P. Industrialização de geléias. Campinas : Instituto de Tecnologia de Alimentos, 1991. 206p. (ITAL. Manual Técnico).

SOUZA FILHO, M. S. M.; FONSECA, J. L. F.; SARMENTO, S. G. R. Processamento e estabilidade do xarope de cajú (Anacardium occidentale, L.). Boletim do Centro de Pesquisa e Processamento de Alimentos, v. 10, n.1, p. 53-58, jan./jun., 1992.

STILLMAN, J. A. Color influences flavor identification in fruit-flavored beverages. Journal of Food Science, v.58, n.4, p.810-812, 1993.

STRINGUETTO, K. Dietético ou não, o importante é ser doce. Alimentação e Nutrição, v. 11, n. 48, p. 24-30, mar. 1991.

SUCOS de frutas- um mercado em desenvolvimento. Alimentos e Bebidas, v.1, n.5, p. $48-50$, ago./set. 1989.

TOLEDO, M. C. F. Considerações sobre avaliação toxicológica de aditivos para alimentos. Alimentos e Tecnologia, v.2, n.12, p.62-63, nov./dez. 1986. 
TRESSLER, D. K.; JOSLYN, M. A. Fruits and vegetable juice processing technology. Westport : The AVI Publ., 1961. 1028p.

UBOLDI EIROA, M. N. Microrganismos deteriorantes de sucos de frutas e medidas de controle. Boletim da Sociedade Brasileira de Ciência e Tecnologia de Alimentos, v.23, n.3/4, p. 141-160, jul./dez. 1989.

VOLPI, L. Aditivos alimentares. Alimentação e Nutrição, v.6, n.23. p.4044, set. 1985.

WAFA, F. Y.; RAO, V. N. M. Some physiochemical and sensory characteristics of peach nectar stored in various packaging materials under ambient conditions. Journal of Food Science, v.2, n.54, p.401404, 1989. 